\title{
Anionic Boron- and Carbon-Based Hetero-Diradicaloids Spanned by a $p$-Phenylene Bridge
}

Avijit Maiti, ${ }^{\dagger}$ Fangyuan Zhang, ${ }^{\ddagger}$ Ivo Krummenacher,, Moulika Bhattacharyya, ${ }^{\dagger}$ Sakshi Mehta, ${ }^{\S}$

Michael Moos, ${ }^{\ddagger}$ Christoph Lambert, ${ }^{\ddagger}$ Bernd Engels, ${ }^{* \bar{\top}}$ Abhishake Mondal, ${ }^{* \S}$ Holger

Braunschweig, ${ }^{* \#}$ Prince Ravat, ${ }^{* \ddagger}$ and Anukul Jana*†

${ }^{\dagger}$ Tata Institute of Fundamental Research Hyderabad, Gopanpally, Hyderabad-500046, India

${ }^{\ddagger}$ Institute of Organic Chemistry, University of Würzburg, Am Hubland, 97074 Würzburg, Germany

\#Institute of Inorganic Chemistry and Institute for Sustainable Chemistry \& Catalysis with Boron (ICB), Julius-

Maximilians-Universität Würzburg, Am Hubland, 97074 Würzburg, Germany

${ }^{\S}$ Solid State and Structural Chemistry Unit, Indian Institute of Science, Bangalore 560012, India

${ }^{\bar{T}}$ Institut für Physikalische und Theoretische Chemie, Julius-Maximilians-Universität Würzburg, Emil-Fischer-Strasse 42, 97074 Würzburg, Germany

1. Content S1

2. General Considerations S2

3. Experimental Details and Analytical Data S3

4. NMR Spectra S10

5. UV/Vis/NIR Spectra $\quad$ S18

6. Molecular Structures of $\mathbf{2}^{\text {Dip }}, \mathbf{3}^{\text {Dip }}, \mathbf{4}^{\text {iPr }}$, and $\mathbf{5}^{\text {iPr }} \quad$ S26

7. Crystallographic Details $\quad$ S28

8. EPR Spectroscopy S36

9. Cyclic Voltammetry and Spectroelectrochemistry S38

10. Quantum Chemical Calculations $\quad$ S41

$\begin{array}{ll}\text { 11. References } & \text { S53 }\end{array}$ 


\section{General Considerations}

All experiments were carried out under an argon atmosphere using standard Schlenk techniques or in a PL-HE-2GB Innovative Technology GloveBox and MBraun Unilab SP GloveBox. Hexane, diethyl ether, THF, and toluene were dried by PS-MD-5 Innovative Technology solvent purification system. 1,4-Dibromobenzene (Sigma Aldrich), potassium (Sigma Aldrich)), nBuLi (Hychem Laboratories), Mel (Hychem Laboratories), MeOTf (Sigma Aldrich) were commercially purchased and used as it is. Mel (Hychem Laboratories) was distilled under $\mathrm{N}_{2}$ atmosphere prior to use. 18-Crown-6 (Sigma Aldrich) was purified by recrystallization from a saturated hot acetonitrile solution and drying the crystalline compounds at $90{ }^{\circ} \mathrm{C}$ under vacuum prior to use. $\mathrm{Mes}_{2} \mathrm{BF}^{\mathrm{S} 1}$ and $\mathrm{KC}_{8} \mathrm{~S}^{2}$ were synthesized according to literature procedure. THF- $d_{8}$ was dried and distilled over potassium under nitrogen. $\mathrm{CDCl}_{3}$ and $\mathrm{CD}_{3} \mathrm{CN}_{\text {were }}$ dried and distilled over $\mathrm{CaH}_{2}$ under argon. NMR spectra were recorded on a BrukerNanoBay $300 \mathrm{MHz}$ NMR spectrometer. ${ }^{1} \mathrm{H}$ and ${ }^{13} \mathrm{C}\left\{{ }^{1} \mathrm{H}\right\}$ NMR spectra were referenced to the peaks of residual protons of the deuterated solvent $\left({ }^{1} \mathrm{H}\right)$ or the deuterated solvent itself $\left({ }^{13} \mathrm{C}\left\{{ }^{1} \mathrm{H}\right\}\right) .{ }^{11} \mathrm{~B}$ NMR spectra were referenced to external $\mathrm{BF}_{3} \cdot \mathrm{OEt}_{2} .{ }^{19} \mathrm{~F}\left\{{ }^{1} \mathrm{H}\right\} \mathrm{NMR}$ spectra were referenced to external tol-CF3.

Elemental analyses of $2^{\text {Dip }}, 3^{\text {Dip }}, 4^{\text {Dip }}, 4^{\text {iPr }}, 5^{\text {Dip }}, 5^{\text {iPr }}$, and $6^{\text {Dip }}$ were performed on an Elementar vario MICRO cube elemental analyzer. UV/Vis spectra were acquired using a Jasco V-670 spectrometer using quartz cells with a path length of $0.1 \mathrm{~cm}$. Melting points were determined in closed NMR tubes under argon atmosphere and are uncorrected. Cyclic voltammetry experiments were performed in THF with $0.1 \mathrm{M}\left[\mathrm{Bu}_{4} \mathrm{~N}\right]\left[\mathrm{PF}_{6}\right]$ as supporting electrolyte using a Gamry Instruments Reference 600 potentiostat. A standard three-electrode cell configuration was employed using a platinum disk working electrode, a platinum wire counter electrode, and a $\mathrm{Ag} / \mathrm{AgCl}$ serving as reference electrode. The redox potentials were referenced to the ferrocene (Fc) / ferrocenium $\left(\mathrm{Fc}^{+}\right)$redox couple. Thin layer measurements were done by attaching the working electrode to the flat surface of a glass halfsphere and measuring 10 cycles with a scan speed of $2 \mathrm{mVs}^{-1}$. Spectroelectrochemical experiments in reflection mode were performed using an Agilent Cary 5000 spectrometer in combination with a custom designed sample compartment consisting of a cylindrical PTFE cell with an Infrasil ${ }^{\circledR}$ wedge window (angled by $0.5^{\circ}$ ) and an adjustable two-in-one electrode ( $6 \mathrm{~mm}$ platinum disc working electrode, $1 \mathrm{~mm}$ platinum wire counter electrode). The potentials were adjusted with a Princeton Applied Research potentiostat (PAR 283) and referenced to a leak free $\mathrm{Ag} / \mathrm{AgCl}$ reference electrode (Warner Instruments). All experiments were measured at room temperature under an argon atmosphere. HRMS of $6^{\text {Dip }}$ and $5^{\text {iPr }}$ were measured on an Exactive Plus Orbitrap-HRMS manufactured by Thermo Scientific. Mass spectrometry of $\mathbf{2}^{\text {Dip }}, \mathbf{3}^{\text {Dip }}, \mathbf{4}^{\text {Dip }}$, and $4^{\text {iPr }}$ were performed on a Bruker Daltonics micrOTOF focus (ESI) system. EPR measurements at X-band $(9.38 \mathrm{GHz})$ were carried out using a Bruker ELEXSYS E580 CW EPR spectrometer equipped with an Oxford Instruments helium cryostat (ESR900) and a MercuryiTC temperature controller. The spectral analysis was performed using MATLAB 8.6.0.267246 (R2015b) and the Optimization toolbox. The spectral simulations were performed using MATLAB 9.8.0.1323502 (R2020a) and the EasySpin 5.2.28 toolbox. ${ }^{\mathrm{S3}}$ 


\section{Experimental Details and Analytical Data}

\section{Synthesis of $2^{\text {Dip }}$}

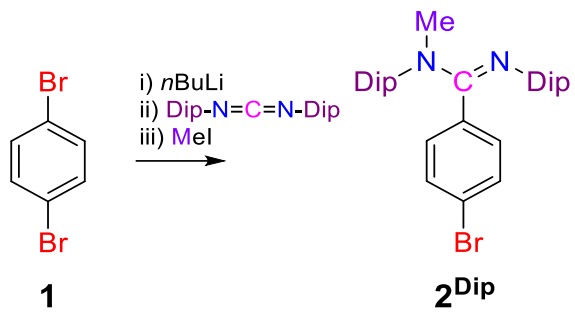

$22.20 \mathrm{~mL}$ of $n$ BuLi (35.5 mmol, $1.6 \mathrm{M}$ in hexane) was added dropwise into a $100 \mathrm{~mL}$ Schlenk flask containing $8 \mathrm{~g}$ of 1,4-dibromobenzene $(33.9 \mathrm{mmol})$ in $60 \mathrm{~mL}$ of THF at $-78^{\circ} \mathrm{C}$ and stirred for 30 mins at that temperature. Then -78 ${ }^{\circ} \mathrm{C}$ precooled THF solution of bis-(2,6-diisopropylphenyl)carbodiimide (11.70 g, $32.27 \mathrm{mmol}$, in $30 \mathrm{~mL}$ THF) was added by a cannula to the resulting white turbid solution, maintaining $-78^{\circ} \mathrm{C}$ temperature of both the Schlenk flasks. After completion of the addition, the resulting light yellow color solution was stirred for $1 \mathrm{hr}$ at $-78^{\circ} \mathrm{C}$. After that, it was slowly bought to room temperature within $2 \mathrm{hrs}$ and further stirred for $2 \mathrm{hrs}$ at room temperature. Subsequently, the reaction mixture was cooled down to $-78{ }^{\circ} \mathrm{C}$ and $3.16 \mathrm{~mL}$ of methyl iodide $(50 \mathrm{mmol})$ was added dropwise using syringe maintaining $-78^{\circ} \mathrm{C}$ temperature of the reaction mixture. Then the resulting reaction mixture slowly bought to room temperature within $2 \mathrm{hrs}$ and was stirred further overnight at room temperature. Subsequently, after removing all the volatiles in vacuo it leads to a white solid residue. Then the resulting solid residue was poured into a mixture of $60 \mathrm{~mL}$ of DCM and $30 \mathrm{~mL}$ of water, and DCM layer was extracted. Further water layer was extracted two times using DCM $(50 \mathrm{~mL} \times 2)$. After that all the combined organic layer was dried by passing through anhydrous $\mathrm{Na}_{2} \mathrm{SO}_{4}$ and evaporation of the resulting filtrate gives $2^{\text {Dip }}$ as a white solid. Suitable single crystals for X-ray diffraction analysis were grown by a slow evaporation of saturated DCM solution of it. Yield: 11.9 g (69 \%). M.P.: $110-112{ }^{\circ} \mathrm{C}$. ${ }^{1} \mathrm{H}$ NMR (300 MHz, CDCl, 298 K): $\delta=7.18-7.13$ (m, 1H, Dip-H), 7.05-7.00 (m, 4H, Ph-H), 6.95-6.94 (m, 2H, Dip-H), 6.89-6.87 (m, 1H, Dip-H), 6.74 (s, 1H, Dip-H), 6.71 (s, 1H, Dip-H), $3.44\left(\mathrm{~s}, 3 \mathrm{H}, \mathrm{NCH}_{3}\right), 3.37\left(\mathrm{sept},{ }^{3} J_{(\mathrm{H}, \mathrm{H})}=6.8 \mathrm{~Hz}, 2 \mathrm{H}\right.$, $\left.\operatorname{Dip}-\mathrm{CH}\left(\mathrm{CH}_{3}\right)_{2}\right), 3.09\left(\mathrm{sept},{ }^{3} J_{(\mathrm{H}, \mathrm{H})}=6.83 \mathrm{~Hz}, 2 \mathrm{H}, \operatorname{Dip}-\mathrm{CH}\left(\mathrm{CH}_{3}\right)_{2}\right), 1.26\left(\mathrm{~d},{ }^{3} J_{(\mathrm{H}, \mathrm{H})}=6.74 \mathrm{~Hz}, 6 \mathrm{H}, \mathrm{Dip}-\mathrm{CH}(\mathrm{CH})_{2}\right), 1.22\left(\mathrm{~d},{ }^{3} J_{(\mathrm{H}}\right.$, $\left.\mathrm{H})=6.74 \mathrm{~Hz}, 6 \mathrm{H}, \operatorname{Dip}-\mathrm{CH}\left(\mathrm{CH}_{3}\right)_{2}\right), 1.16\left(\mathrm{~d},{ }^{3} J_{(\mathrm{H}, \mathrm{H})}=6.85 \mathrm{~Hz}, 6 \mathrm{H}, \operatorname{Dip}-\mathrm{CH}\left(\mathrm{CH}_{3}\right)_{2}\right), 1.03\left(\mathrm{~d},{ }^{3} J_{(\mathrm{H}, \mathrm{H})}=6.93 \mathrm{~Hz}, 6 \mathrm{H}, \mathrm{Dip}-\mathrm{CH}(\mathrm{CH})_{2}\right)$ ppm. ${ }^{13} \mathrm{C}\left\{{ }^{1} \mathrm{H}\right\}$ NMR (75.4 MHz, CDCl, $298 \mathrm{~K}$ ): $\delta=155.54$ (NCN), 146.85 (N-DipC), 145.27 (N-DipC), 140.55 (DipC), 137.96 (DipC), 131.96 (NCN-PhC), 130.17 (PhC), 130.09 (PhC), 128.14 (PhC), 124.11 (BrPhC), 122.43 (DipC), 121.86 (DipC), $40.48\left(\mathrm{NCH}_{3}\right), 28.44\left(\mathrm{DipCH}\left(\mathrm{CH}_{3}\right)_{2}\right), 28.36\left(\mathrm{DipCH}\left(\mathrm{CH}_{3}\right)_{2}\right), 26.36\left(\mathrm{DipCH}\left(\mathrm{CH}_{3}\right)_{2}\right), 24.19\left(\mathrm{DipCH}\left(\mathrm{CH}_{3}\right)_{2}\right), 22.80$ (DipCH(CH$)_{2}$ ), 22.10 (DipCH(CH$)_{2}$ ) ppm. Elemental Analysis(\%): calculated for $\mathrm{C}_{32} \mathrm{H}_{41} \mathrm{BrN}_{2}$ : C 72.03, $\mathrm{H} 7.75, \mathrm{~N}$ 5.25; Found: C 72.71; H 7.87; N 5.19. HRMS (ESI+): (m/z) calculated forC ${ }_{32} \mathrm{H}_{42} \mathrm{BrN}_{2}\left([\mathrm{M}+\mathrm{H}]^{+}\right)$: 533.2531, Found: 533.2516. 


\section{Synthesis of $3^{\text {Dip }}$}

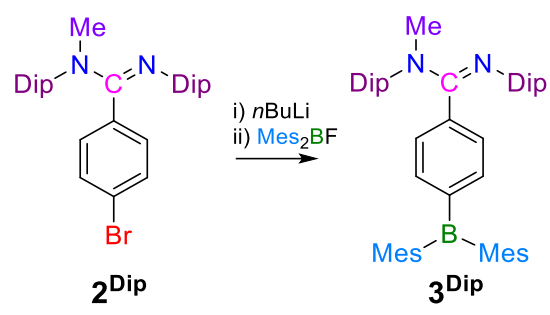

$2.34 \mathrm{~mL}$ of $n \mathrm{BuLi}(3.75 \mathrm{mmol}, 1.6 \mathrm{M}$ in hexane) was added dropwise to the $100 \mathrm{~mL}$ Schlenk flask containing THF solution of $2^{\text {Dip }}(1.82 \mathrm{~g}, 3.41 \mathrm{mmol}$, in $60 \mathrm{~mL} \mathrm{THF})$ at $-78^{\circ} \mathrm{C}$. The resulting reaction mixture was stirred for $30 \mathrm{mins}$ at $-78{ }^{\circ} \mathrm{C}$. After that THF solution of Mes2 BF $\left(0.91 \mathrm{~g}, 3.41 \mathrm{mmol}\right.$, in $20 \mathrm{~mL}$ THF) was added by using cannula at $-78{ }^{\circ} \mathrm{C}$ and slowly raised the temperature to $-20^{\circ} \mathrm{C}$. Then the reaction mixture was stirred $4 \mathrm{hrs}$ at $-20^{\circ} \mathrm{C}$ before warmed up to room temperature and stirred for overnight. Subsequently all the volatiles were removed in vacuo and the resulting oily residue was extracted with $60 \mathrm{~mL}$ of hexane as $3^{\text {Dip }}$. After evaporation all the solvent it was titurated with $20 \mathrm{~mL}$ of pentane and then filtered the silution to get pure $3^{\text {Dip }}$ as a residue. Subsequently, filtrate was kept to get second corp of 3. Yield: $2.1 \mathrm{~g}$ (87\%) M.P.: $181-183{ }^{\circ} \mathrm{C} .{ }^{1} \mathbf{H}$ NMR for $3^{\text {Dip }}\left(300 \mathrm{MHz}, \mathrm{CDCl}_{3}, 298 \mathrm{~K}\right): \delta=7.14-7.09$ (m, 1H, Dip-H), 7.03-6.96 (m, 4H, Ph-H), 6.90-6.88 (m, 2H, Dip-H), 6.84-6.79 (m, 3H, Dip-H), 6.73 (s, $4 \mathrm{H}$, Mes-H) 3.49 (s, $\left.3 \mathrm{H}, \mathrm{NCH}_{3}\right), 3.37\left(\mathrm{sept},{ }^{3} J_{(\mathrm{H}, \mathrm{H})}=6.81 \mathrm{~Hz}, 2 \mathrm{H}, \mathrm{Dip}-\mathrm{CH}\left(\mathrm{CH}_{3}\right)_{2}\right), 3.15\left(\mathrm{sept},{ }^{3} J_{(\mathrm{H}, \mathrm{H})}=6.88 \mathrm{~Hz}, 2 \mathrm{H}, \operatorname{Dip}-\mathrm{CH}\left(\mathrm{CH}_{3}\right)_{2}\right), 2.27(\mathrm{~s}, 6 \mathrm{H}$, Mes- $\left.\mathrm{CH}_{3}\right), 1.74\left(\mathrm{~s}, 12 \mathrm{H}\right.$, Mes- $\left.\mathrm{CH}_{3}\right), 1.27\left(\mathrm{~d},{ }^{3} J_{(\mathrm{H}, \mathrm{H})}=6.80 \mathrm{~Hz}, 6 \mathrm{H}, \operatorname{Dip}-\mathrm{CH}\left(\mathrm{CH}_{3}\right)_{2}\right), 1.22\left(\mathrm{~d},{ }^{3} J_{(\mathrm{H}, \mathrm{H})}=6.74 \mathrm{~Hz}, 6 \mathrm{H}, \mathrm{Dip}-\right.$ $\left.\mathrm{CH}\left(\mathrm{CH}_{3}\right)_{2}\right), 1.12\left(\mathrm{~d},{ }^{3} J_{(\mathrm{H}, \mathrm{H})}=6.84 \mathrm{~Hz}, 6 \mathrm{H}, \operatorname{Dip}-\mathrm{CH}\left(\mathrm{CH}_{3}\right)_{2}\right), 1.00\left(\mathrm{~d},{ }^{3} \mathrm{~J}_{(\mathrm{H}, \mathrm{H})}=6.96 \mathrm{~Hz}, 6 \mathrm{H}, \mathrm{Dip}-\mathrm{CH}\left(\mathrm{CH}_{3}\right)_{2}\right) \mathrm{ppm} .{ }^{13} \mathrm{C}\left\{{ }^{1} \mathrm{H}\right\} \mathbf{N M R}$ (75.4 MHz, CDCl 298 K): $\delta=156.28$ (NCN), 146.88, 145.56, 140.85, 138.69, 137.96, 136.23, 134.30, 128.41, 122.26, 121.66, $40.34\left(\mathrm{NCH}_{3}\right), 28.38\left(\mathrm{DipCH}\left(\mathrm{CH}_{3}\right)_{2}\right), 28.32\left(\mathrm{DipCH}\left(\mathrm{CH}_{3}\right)_{2}\right), 26.35\left(\mathrm{DipCH}\left(\mathrm{CH}_{3}\right)_{2}\right), 24.19\left(\mathrm{DipCH}\left(\mathrm{CH}_{3}\right)_{2}\right), 23.19$ (Mes- $\left.\mathrm{CH}_{3}\right), 22.71\left(\mathrm{DipCH}\left(\mathrm{CH}_{3}\right)_{2}\right), 22.08\left(\mathrm{DipCH}\left(\mathrm{CH}_{3}\right)_{2}\right), 21.20\left(\mathrm{Mes}-\mathrm{CH}_{3}\right)$ ppm. Elemental Analysis(\%): calculated for $\mathrm{C}_{50} \mathrm{H}_{63} \mathrm{BN}_{2}$ : C 85.44, H 9.03, N 3.99; Found: C 84.72, H 9.23, N 4.07. HRMS (ESI+): (m/z) calculated forC ${ }_{50} \mathrm{H}_{64} \mathrm{BN}_{2}$ $\left([\mathrm{M}+\mathrm{H}]^{+}\right):$703.5162, Found: 703.5195 .

\section{Synthesis of $4^{\text {Dip }}$}

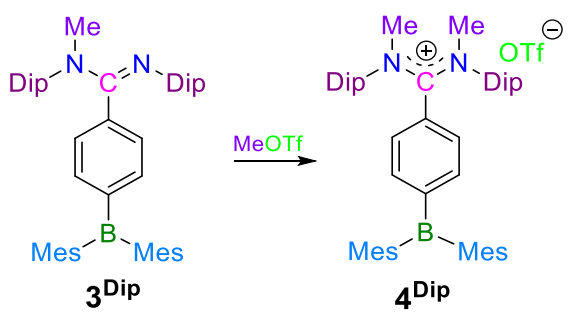

Hexane solution of MeOTf $\left(0.46 \mathrm{~mL}, 4.1 \mathrm{mmol}\right.$, in $10 \mathrm{~mL}$ of hexane) was added to a hexane solution of $3^{\text {Dip }}$ (2.4 gm, $3.41 \mathrm{mmol}$, in $20 \mathrm{~mL}$ of hexane) obtained from the above reaction considering quantitative yield at $-78{ }^{\circ} \mathrm{C}$. After stirring 30 mins at $-78{ }^{\circ} \mathrm{C}$ the resulting mixture was slowly warmed to room temperature and stirred for 12 hrs. Resulting white turbid solution was filtered and the resulting residue was washed with $30 \mathrm{~mL}$ of Et ${ }_{2} \mathrm{O}$ to get pure product of $4^{\text {Dip }}$ as white solids. Suitable single crystals for single crystal X-ray diffraction study were obtained by slow 
$\mathrm{Et}_{2} \mathrm{O}$ diffusion in saturated acetonitrile solution of it. Yield: $2.4 \mathrm{~g}(81 \%)$. M.P.: $163-165^{\circ} \mathrm{C} .{ }^{1} \mathrm{H}$ NMR $\left(300 \mathrm{MHz}, \mathrm{CD}_{3} \mathrm{CN}\right.$, $298 \mathrm{~K}): \delta=7.64-7.59(\mathrm{~m}, 1 \mathrm{H}, \mathrm{Dip}-H), 7.48-7.46(\mathrm{~m}, 4 \mathrm{H}, \mathrm{Ph}-H), 7.42-7.36(\mathrm{~m}, 2 \mathrm{H}, \mathrm{Dip}-H), 7.22-7.17$ (m, 1H, Dip-H), 7.09$7.03(\mathrm{~m}, 2 \mathrm{H}, \mathrm{Dip}-H), 6.82\left(\mathrm{~s}, 4 \mathrm{H}\right.$, Mes- $H$ ), $3.38\left(\mathrm{sept},{ }^{3} \mathrm{~J}_{(\mathrm{H}, \mathrm{H})}=6.85 \mathrm{~Hz}, 2 \mathrm{H}, \operatorname{Dip}-\mathrm{CH}\left(\mathrm{CH}_{3}\right)_{2}\right), 3.26\left(\mathrm{~s}, 3 \mathrm{H}, \mathrm{NCH}_{3}\right), 3.01$ (sept, $\left.3 J_{(H, H)}=6.75 \mathrm{~Hz}, 2 \mathrm{H}, \operatorname{Dip}-\mathrm{CH}\left(\mathrm{CH}_{3}\right)_{2}\right), 2.97\left(\mathrm{~s}, 3 \mathrm{H}, \mathrm{NCH}_{3}\right), 2.27\left(\mathrm{~s}, 6 \mathrm{H}, \mathrm{Mes}-\mathrm{CH}_{3}\right), 1.77\left(\mathrm{~s}, 12 \mathrm{H}, \mathrm{Mes}-\mathrm{CH}_{3}\right), 1.53\left(\mathrm{~d},{ }^{3} \mathrm{~J}_{(\mathrm{H}, \mathrm{H})}=\right.$ $\left.6.80 \mathrm{~Hz}, 6 \mathrm{H}, \mathrm{Dip}-\mathrm{CH}\left(\mathrm{CH}_{3}\right)_{2}\right), 1.36\left(\mathrm{~d},{ }^{3} J_{(\mathrm{H}, \mathrm{H})}=6.70 \mathrm{~Hz}, 6 \mathrm{H}, \mathrm{Dip}-\mathrm{CH}\left(\mathrm{CH}_{3}\right)_{2}\right), 1.32\left(\mathrm{~d},{ }^{3} J_{(\mathrm{H}, \mathrm{H})}=6.70 \mathrm{~Hz}, 6 \mathrm{H}, \mathrm{Dip}-\mathrm{CH}\left(\mathrm{CH}_{3}\right)_{2}\right)$, $1.11\left(\mathrm{~d},{ }^{3} \mathrm{~J}_{(\mathrm{H}, \mathrm{H})}=6.70 \mathrm{~Hz}, 6 \mathrm{H}\right.$, Dip-CH(CH3) 2$)$ ppm. ${ }^{13} \mathrm{C}\left\{{ }^{1} \mathrm{H}\right\} \mathrm{NMR}\left(75.4 \mathrm{MHz}, \mathrm{CD}_{3} \mathrm{CN}, 298 \mathrm{~K}\right): \delta=165.21(\mathrm{NCN}), 145.88$, $145.84,144.16,142.13,141.78,140.77,138.16,136.21,133.31,132.03$ (q, CF $), 129.27,126.94,126.61,126.27$, 125.93, 125.78, $50.89\left(\mathrm{NCH}_{3}\right), 46.17\left(\mathrm{NCH}_{3}\right), 30.24\left(\mathrm{DipCH}\left(\mathrm{CH}_{3}\right)_{2}\right), 29.86\left(\operatorname{DipCH}\left(\mathrm{CH}_{3}\right)_{2}\right), 26.56\left(\operatorname{DipCH}\left(\mathrm{CH}_{3}\right)_{2}\right), 26.01$ (DipCH$\left.\left(\mathrm{CH}_{3}\right)_{2}\right), 23.54$ (Mes- $\left.\mathrm{CH}_{3}\right), 23.04\left(\mathrm{DipCH}\left(\mathrm{CH}_{3}\right)_{2}\right), 22.56\left(\mathrm{DipCH}\left(\mathrm{CH}_{3}\right)_{2}\right), 21.26\left(\mathrm{Mes}^{-} \mathrm{CH}_{3}\right)$ ppm. ${ }^{19} \mathrm{~F}\left\{{ }^{1} \mathrm{H}\right\}$ NMR $(282.2$ $\left.\mathrm{MHz}, \mathrm{CD}_{3} \mathrm{CN}, 298 \mathrm{~K}\right): \delta=-79.31 \mathrm{ppm}$. UV/Vis (THF): $\lambda_{\max }(\varepsilon)=324(10282) \mathrm{nm}\left(\mathrm{Lmol}^{-1} \mathrm{~cm}^{-1}\right)$. Elemental Analysis(\%): calculated for $\mathrm{C}_{52} \mathrm{H}_{66} \mathrm{BF}_{3} \mathrm{~N}_{2} \mathrm{O}_{3} \mathrm{~S}$ :. C 72.04, H 7.67, N 3.23, S 3.70; Found: C 71.32, H 7.77, N 3.07, S 3.41. HRMS (ESI+): $(\mathrm{m} / \mathrm{z})$ calculated forC $\mathrm{C}_{51} \mathrm{H}_{66} \mathrm{BN}_{2}\left([\mathrm{M}-\mathrm{OTf}]^{+}\right):$717.5314, Found: 717.5315 .

\section{Synthesis of $5^{\text {Dip }}$}
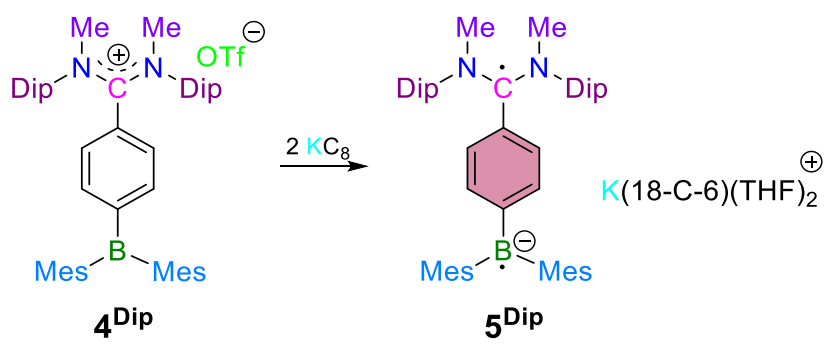

$30 \mathrm{~mL}$ of precooled $\left(-78^{\circ} \mathrm{C}\right)$ THF was added to a Schlenk flask containing $4^{\text {Dip }}$ (377 $\left.\mathrm{mg}, 0.44 \mathrm{mmol}\right)$ and $\mathrm{KC}_{8}(130 \mathrm{mg}$, $0.96 \mathrm{mmol}$ ) at $-78^{\circ} \mathrm{C}$ and slowly bought to room temperature in a $4 \mathrm{hrs}$. After that it was stirred for another $12 \mathrm{hrs}$ at room temperature. Subsequently all the volatilities were removed in vacuo and the resulting residue was extracted with $20 \mathrm{~mL}$ ( $\times 2$ ) of warm toluene. After removing all the solvent of the combining filtrate it was washed with $30 \mathrm{~mL}$ of hexane which leads to a red solid. After that $115 \mathrm{mg}$ of 18 -crown-6 $(0.44 \mathrm{mmol})$ and $30 \mathrm{ml}$ toluene was added into it and stirred for $4 \mathrm{hrs}$. Then all the volatiles were removed in vacuo and the resulting residue was washed with $30 \mathrm{~mL}$ of hexane. After that it was extracted with $20 \mathrm{ml}(\mathrm{x} 2)$ THF and the combine filtrate was concentrated to about $10 \mathrm{~mL}$. Then it was layered with $5 \mathrm{~mL}$ of toluene and then $5 \mathrm{~mL}$ of hexane, sequentially and kept at $-30^{\circ} \mathrm{C}$ for 3 days. The resulting red crystals of $5^{\text {Dip }}$ is also suitable for single crystal X-ray diffraction study. Yield: $323 \mathrm{mg}$ (63 \%). M.P.: $140{ }^{\circ} \mathrm{C}$. UV/Vis (THF): $\lambda_{\max }(\varepsilon)=443$ (10384), 545 (29323), $717(2887) \mathrm{nm}\left(\mathrm{Lmol}^{-1} \mathrm{~cm}^{-1}\right)$. Elemental Analysis(\%): calculated for $\mathrm{C}_{71} \mathrm{H}_{106} \mathrm{BKN}_{2} \mathrm{O}_{8}$ : C 73.17, H 9.17, N 2.40 ; Found: C 73.18, H 9.11, N 2.27. 
Synthesis of $6^{\text {Dip }}$

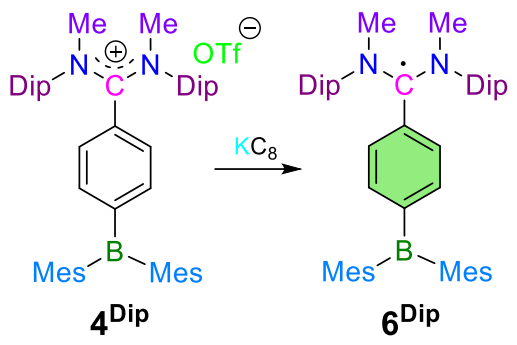

$30 \mathrm{~mL}$ of precooled $\left(-78^{\circ} \mathrm{C}\right)$ THF was added to a Schlenk flask containing $4^{\text {Dip }}(500 \mathrm{mg}, 0.576 \mathrm{mmol})$ and $\mathrm{KC} 8$ (77 mg, $0.576 \mathrm{mmol}$ ) at $-78^{\circ} \mathrm{C}$ and slowly bought to room temperature in a $4 \mathrm{hrs}$. After that it was stirred for another $12 \mathrm{hrs}$ at room temperature. Subsequently all the volatilities were removed in vacuo and the resulting residue was extracted with $20 \mathrm{~mL}(\times 2)$ of hexane. After removing all the solvent of the combining filtrate $6^{\text {Dip }}$ was obtained as dark green solid. Single crystals suitable for single crystal X-ray diffraction study were obtained from saturated hexane solution at $-30{ }^{\circ} \mathrm{C}$ after 2 days. Yield: $151 \mathrm{mg}(36 \%)$. M.P.: $104^{\circ} \mathrm{C}$. UV/Vis (THF): $\lambda_{\max }(\varepsilon)=439(16294)$, 717 (14458) $\mathrm{nm}\left(\mathrm{Lmol}^{-1} \mathrm{~cm}^{-1}\right)$. Elemental Analysis(\%): calculated for $\mathrm{C}_{51} \mathrm{H}_{66} \mathrm{BN}_{2}$ : C 85.33, H 9.27, N 3.90; Found: C 84.80, H 9.56, N 3.67. HRMS (LIFDI): calculated for $\mathrm{C}_{51} \mathrm{H}_{66} \mathrm{BN}_{2}$ ([M]) 717.5314, Found 717.5302.

\section{Comproportionation reaction between $4^{\text {Dip }}$ and $5^{\text {Dip }}$ to $6^{\text {Dip }}$}
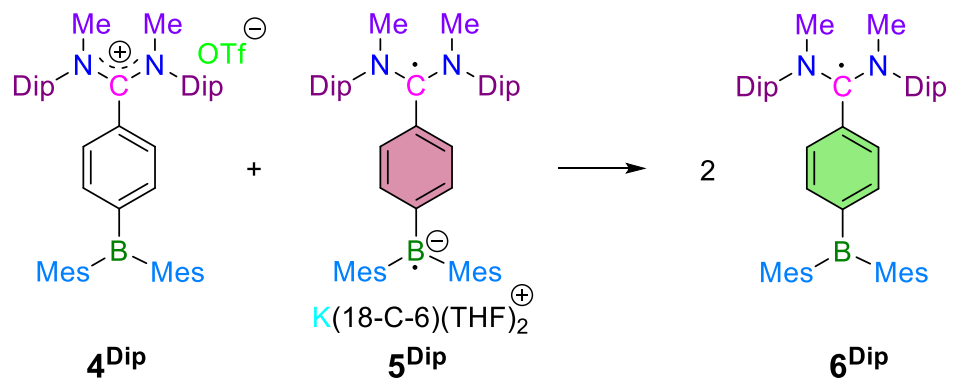

$5 \mathrm{~mL}$ of THF was added to a mixture of $5^{\text {Dip }}(8 \mathrm{mg}, 0.006 \mathrm{mmol})$ and $4^{\text {Dip }}(6 \mathrm{mg}, 0.006 \mathrm{mmol})$ in a $5 \mathrm{~mL}$ volumetric flask at room temperature. After gentle shaking $6^{\text {Dip }}$ was obtained as green colored solution as confirmed by UV/Vis spectroscopy. For UV/Vis measurement $1 \mathrm{~mL}$ stock solution was taken and $9 \mathrm{~mL}$ THF was added for dilution. 


\section{Oxidation of $5^{\text {Dip }}$ to $6^{\text {Dip }}$}

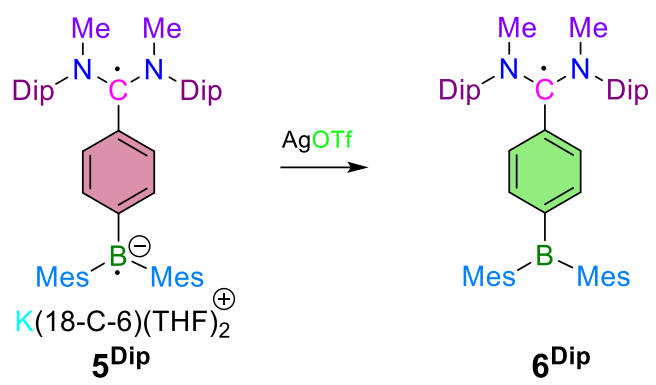

$10 \mathrm{~mL}$ of THF was added to a mixture of $5^{\text {Dip }}(36 \mathrm{mg}, 0.030 \mathrm{mmol})$ and AgOTf $(7.9 \mathrm{mg}, 0.030 \mathrm{mmol})$ at room temperature. After stirring $2 \mathrm{hrs}$, all the solvent was evaporated and extracted with $10 \mathrm{~mL}$ of hexane. After evaporating all solvent from the filtrate $6^{\text {Dip }}$ was obtained as green solid compound as confirmed by UV/Vis spectroscopy.

\section{Oxidation of $5^{\text {Dip }}$ to $4^{\text {Dip }}$}

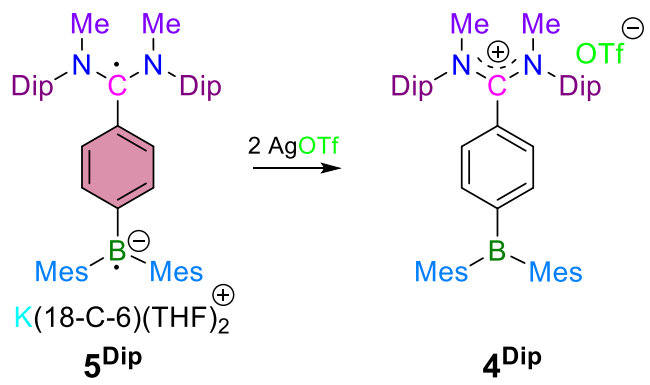

$10 \mathrm{~mL}$ of THF was added to a mixture of $5^{\text {Dip }}(24 \mathrm{mg}, 0.021 \mathrm{mmol})$ and AgOTf $(11.6 \mathrm{mg}, 0.045 \mathrm{mmol})$ at room temperature. After stirring $2 \mathrm{hrs}$, solution was filtered. After evaporating all solvent from the filtrate $\mathbf{4}^{\text {Dip }}$ was obtained as crystalline compound along with $18-$ Crown-6 and KOTf as indicated in NMR spectrum. ${ }^{1} \mathbf{H}$ NMR for $4^{\text {Dip }}$ (300 MHz, CDCl 3,298 K): $\delta=7.61-7.56(\mathrm{~m}, 1 \mathrm{H}, \mathrm{Dip}-H)$, 7.49-7.47 (m, 2H, Ph-H), 7.39-7.37 (m, 2H, Ph-H), 7.33-7.30 (m, 2H, Dip-H), 7.18-7.13 (m, 1H, Dip-H), 6.98-6.95 (m, 2H, Dip-H), 6.77 (s, 4H, Mes-H), 3.62 (s, 24H, 18-C-6), 3.36 (m, 2H, Dip- $\left.\mathrm{CH}\left(\mathrm{CH}_{3}\right)_{2}\right), 3.36$ (s, 3H, NCH3), 2.99 (sept, 2H, Dip- $\left.\mathrm{CH}\left(\mathrm{CH}_{3}\right)_{2}\right), 2.99$ (s, 3H, NCH3), 2.28 (s, $\left.6 \mathrm{H}, \mathrm{Mes}-\mathrm{CH}_{3}\right), 1.77$ (s, $12 \mathrm{H}$, Mes- $\left.\mathrm{CH}_{3}\right), 1.55$ (d, J = 6.75 Hz, 6H, Dip-CH(CH$\left.)_{2}\right), 1.42\left(\mathrm{~d}, J=6.69 \mathrm{~Hz}, 6 \mathrm{H}, \mathrm{Dip}-\mathrm{CH}\left(\mathrm{CH}_{3}\right)_{2}\right), 1.34(\mathrm{~d}, J=6.58 \mathrm{~Hz}, 6 \mathrm{H}$, $\left.\operatorname{Dip}-\mathrm{CH}\left(\mathrm{CH}_{3}\right)_{2}\right), 1.12\left(\mathrm{~d}, J=6.60 \mathrm{~Hz}, 6 \mathrm{H}, \mathrm{Dip}-\mathrm{CH}\left(\mathrm{CH}_{3}\right)_{2}\right)$ ppm. ${ }^{19} \mathrm{~F}\left\{{ }^{1} \mathrm{H}\right\} \mathbf{N M R}(282.2 \mathrm{MHz}, \mathrm{CDCl} 3,298 \mathrm{~K}): \delta=-78.168 \mathrm{ppm}$. 


\section{Synthesis of $4^{i \mathrm{Pr}}$}

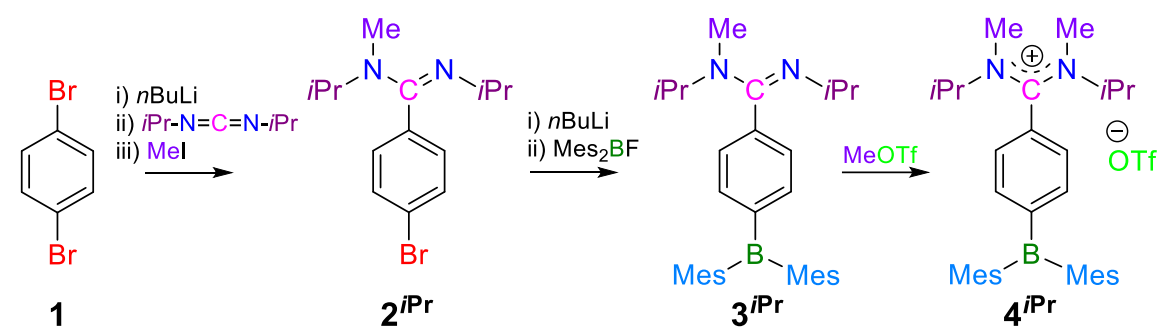

$10 \mathrm{~mL}$ of $n \mathrm{BuLi}$ (15 mmol, $1.6 \mathrm{M}$ in hexane) was added dropwise into a $100 \mathrm{~mL}$ Schlenk flask containing 3.5 g of 1,4dibromobenzene $(14 \mathrm{mmol})$ in $60 \mathrm{~mL}$ of THF at $-78{ }^{\circ} \mathrm{C}$ and stirred for $30 \mathrm{mins}$ at that temperature. Then $-78{ }^{\circ} \mathrm{C}$ precooled THF solution of N,N'-Diisopropylcarbodiimide $(2.8 \mathrm{~g}, 22 \mathrm{mmol}$, in $30 \mathrm{~mL}$ THF) was added by a cannula to the resulting white turbid solution, maintaining $-78{ }^{\circ} \mathrm{C}$ temperature of both the Schlenk flasks. After completion of the addition, the resulting white suspension solution was stirred for $1 \mathrm{hr}$ at $-78^{\circ} \mathrm{C}$. After that, it was slowly brought to room temperature within $2 \mathrm{hrs}$ and further stirred for $2 \mathrm{hrs}$ at room temperature. Subsequently, the reaction mixture was cooled down to $-78{ }^{\circ} \mathrm{C}$ and $1.74 \mathrm{~mL}$ of methyl iodide (28 mmol) was added dropwise using syringe maintaining $-78{ }^{\circ} \mathrm{C}$ temperature of the reaction mixture. Then the resulting reaction mixture slowly brought to room temperature within $2 \mathrm{hrs}$ and was refluxed for $4 \mathrm{hrs}$ to get clear solution. Subsequently, after removing all the volatiles in vacuo residue was extracted with $70 \mathrm{ml}$ hot hexane. After removing all the solvent from filtrate $3.02 \mathrm{gm}$ of $2^{i \mathrm{Pr}}$ was obtained (Yield: $\left.72 \%\right) .6 .35 \mathrm{~mL}$ of $n$ BuLi $(10 \mathrm{mmol}, 1.6 \mathrm{M}$ in hexane) was added dropwise to the $100 \mathrm{~mL}$ Schlenk flask containing THF solution of $2^{i \mathrm{Pr}}(3.024 \mathrm{~g}, 10 \mathrm{mmol}$, in $60 \mathrm{~mL} \mathrm{THF})$ at $-78^{\circ} \mathrm{C}$. The resulting reaction mixture was stirred for 30 mins at $-78^{\circ} \mathrm{C}$. After that THF solution of Mes 2 BF $(2.61 \mathrm{~g}, 10 \mathrm{mmol}$, in $20 \mathrm{~mL}$ THF $)$ was added by using cannula at $-78{ }^{\circ} \mathrm{C}$ and slowly raised the temperature to $-20{ }^{\circ} \mathrm{C}$. Then the reaction mixture was stirred $4 \mathrm{hrs}$ at $-20{ }^{\circ} \mathrm{C}$ before warmed up to room temperature and stirred for overnight. Subsequently all the volatiles were removed in vacuo and the resulting oily residue was extracted with $60 \mathrm{~mL}$ of hexane as $3^{\text {iPr }}$. Hexane solution of MeOTf (1.13 mL, $10 \mathrm{mmol}$, in $10 \mathrm{~mL}$ of hexane) was added to a hexane solution of $3^{i P r}$ obtained from the above reaction considering quantitative yield at $-78{ }^{\circ} \mathrm{C}$. After stirring 30 mins at $-78{ }^{\circ} \mathrm{C}$ the resulting mixture was slowly warmed to room temperature and stirred for $12 \mathrm{hrs}$. Resulting white turbid solution was filtered and the resulting residue was washed with $30 \mathrm{~mL}$ of $\mathrm{Et}_{2} \mathrm{O}$ to get pure product of $4^{\mathrm{iPr}}$ as white solids. Suitable single crystals for single crystal X-ray diffraction study were obtained by slow $\mathrm{Et}_{2} \mathrm{O}$ diffusion in saturated acetonitrile solution of it. Yield: 4.2 g (47 \%). M.P.: $188-192{ }^{\circ} \mathrm{C} .{ }^{1} \mathrm{H}$ NMR (300 MHz, CD 3 CN, $\left.298 \mathrm{~K}\right): \delta=7.62-7.60(\mathrm{~m}, 2 \mathrm{H}, \mathrm{Ph}-H)$, 7.56-7.53 (m, 2H, Ph-H), 6.88(s, 4H, Mes-H), 3.51 (br, 2H, iPr-CH(CH3)2), 3.12 (br, 6H, NCH3), 2.29 (s, 6H, Mes- $\left.\mathrm{CH}_{3}\right), 1.96\left(\mathrm{~s}, 12 \mathrm{H}, \mathrm{Mes}-\mathrm{CH}_{3}\right)$, 1.20-1.19 (br, $\left.12 \mathrm{H}, i \operatorname{Pr}-\mathrm{CH}\left(\mathrm{CH}_{3}\right)_{2}\right)$ ppm. ${ }^{13} \mathrm{C}\left\{{ }^{1} \mathrm{H}\right\}$ NMR (75.4 MHz, CD $\left.{ }_{3} \mathrm{CN}, 298 \mathrm{~K}\right): \delta=171.03(\mathrm{NCN}), 151.95,141.81$, 140.74, 136.92, 133.66, 129.34, $56.32\left(i \mathrm{Pr}-\mathrm{CH}\left(\mathrm{CH}_{3}\right)_{2}\right), 35.36\left(\mathrm{NCH}_{3}\right), 23.66\left(\mathrm{Mes}-\mathrm{CH}_{3}\right), 21.28(\mathrm{Mes}-\mathrm{CH}), 20.28(i \mathrm{Pr}-$ $\left.\mathrm{CH}\left(\mathrm{CH}_{3}\right)_{2}\right)$ ppm. ${ }^{19} \mathrm{~F}\left\{{ }^{1} \mathrm{H}\right\}$ NMR $\left(282.2 \mathrm{MHz}, \mathrm{CD}_{3} \mathrm{CN}, 298 \mathrm{~K}\right): \delta=-79.31 \mathrm{ppm}$. UV/Vis (THF): $\lambda_{\max }(\varepsilon)=322(9729), 265$ (16340) $\mathrm{nm}\left(\mathrm{Lmol}^{-1} \mathrm{~cm}^{-1}\right)$. Elemental Analysis(\%): calculated for $\mathrm{C}_{34} \mathrm{H}_{46} \mathrm{BF}_{3} \mathrm{~N}_{2} \mathrm{O}_{3} \mathrm{~S}: \mathrm{C} 64.76, \mathrm{H} 7.35, \mathrm{~N} \mathrm{4.44,} \mathrm{S} \mathrm{5.08;}$ Found: C 64.67, H 7.62, N 4.52, S 5.31. HRMS (ESI+): (m/z) calculated for ${ }_{33} \mathrm{H}_{46} \mathrm{BN}_{2}\left([\mathrm{M}-\mathrm{OTf}]^{+}\right)$: 481.3749, Found: 481.3744 . 


\section{Synthesis of $5^{i \mathrm{Pr}}$}

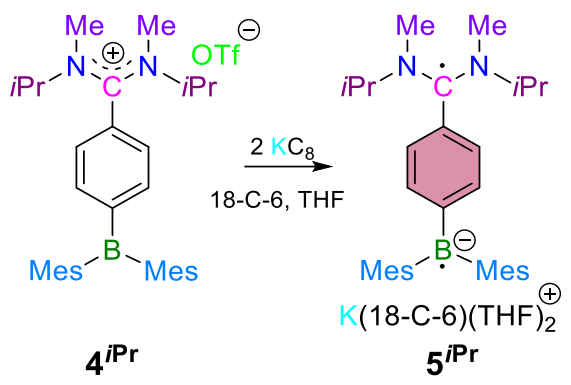

$30 \mathrm{~mL}$ of precooled $\left(-78^{\circ} \mathrm{C}\right) \mathrm{THF}$ was added to a Schlenk flask containing $4^{\text {iPr }}(630 \mathrm{mg}, 0.99 \mathrm{mmol})$ and $\mathrm{KC} 8$ (337 mg, $2.49 \mathrm{mmol}$ ) at $-78^{\circ} \mathrm{C}$ and slowly brought to room temperature in a $4 \mathrm{hrs}$. After that it was stirred for another $12 \mathrm{hrs}$ at room temperature. Subsequently all the volatilities were removed in vacuo and the resulting residue was extracted with $20 \mathrm{~mL}$ (x 2) of toluene. After removing all the solvent of the combining filtrate it was washed with 30 $\mathrm{mL}$ of hexane which leads to a red solid. After that $264 \mathrm{mg}$ of 18-crown-6 (0.99 mmol) and $30 \mathrm{ml}$ toluene was added into it and stirred for $4 \mathrm{hrs}$. Then all the volatiles were removed in vacuo and the resulting residue was washed with $30 \mathrm{~mL}$ of hexane. After that it was extracted with $20 \mathrm{ml}$ (x2) THF and the combine filtrate was concentrated to about $5 \mathrm{~mL}$. Then it was layered with $5 \mathrm{~mL}$ of toluene and then $5 \mathrm{~mL}$ of hexane, sequentially and kept at $-30^{\circ} \mathrm{C}$ for 2 days. The resulting red crystals of $\mathbf{5}^{\mathbf{i P r}}$ is also suitable for single crystal X-ray diffraction study. Yield: 380 mg (41 \%). M.P.: $140{ }^{\circ} \mathrm{C}$. UV/Vis (THF): $\lambda_{\max }(\varepsilon)=343$ (14433), 502 (29149), 707 (3882) nm $\left(\mathrm{Lmol}^{-1} \mathrm{~cm}^{-1}\right)$. Elemental Analysis(\%): calculated for $\mathrm{C}_{53} \mathrm{H}_{86} \mathrm{BKN}_{2} \mathrm{O}_{8}$ : C 68.51, H 9.33, N 3.01; Found: C 67.56, H 8.67, N 2.47. HRMS (ESI+): (m/z) calculated for $\mathrm{C}_{33} \mathrm{H}_{46} \mathrm{BN}_{2}\left(\left[\mathrm{M}-\mathrm{K}(18-\mathrm{C}-6)(\mathrm{THF})_{2}\right]^{+}\right)$: 481.3749, Found 481.3747. 


\section{NMR Spectra}

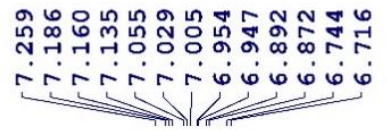

농음

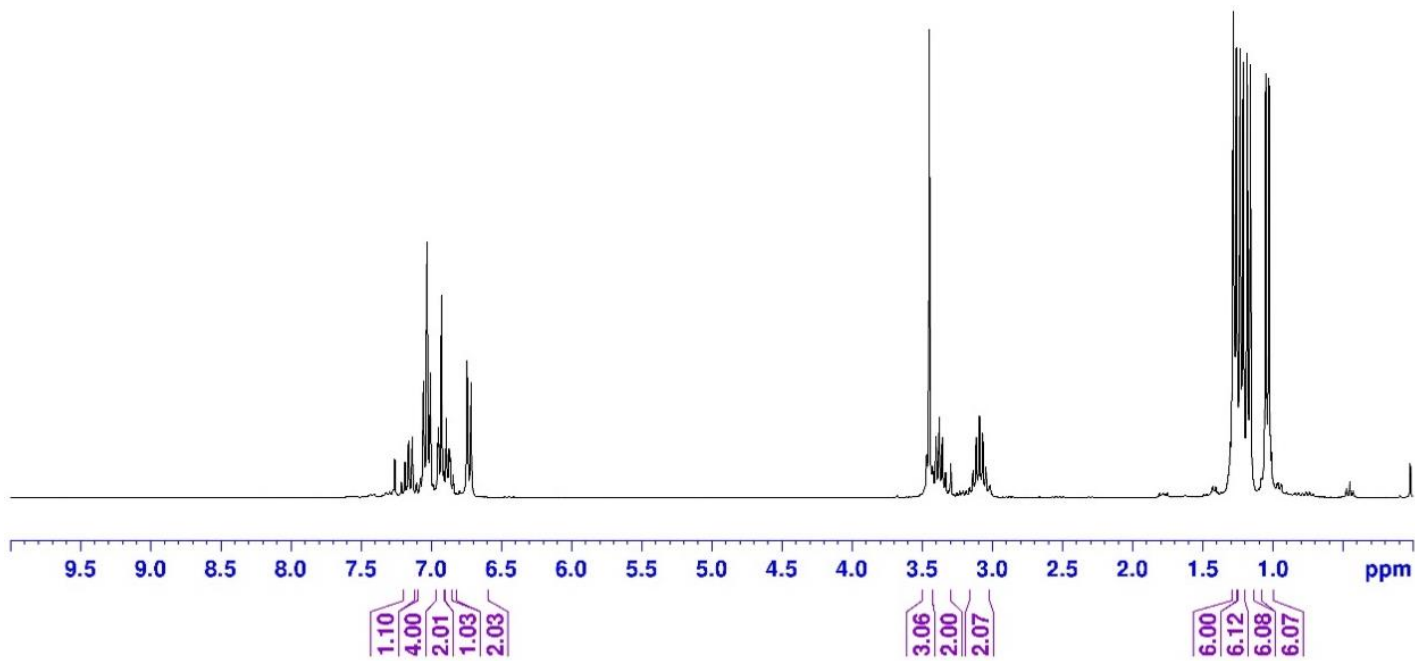

Figure S1. ${ }^{1} \mathrm{H}$ NMR spectrum of $2^{\text {Dip }}$ in $\mathrm{CDCl}_{3}$ at room temperature.

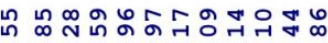

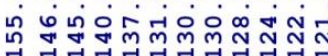

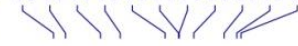

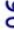

i

ఫิ ఫुले

i

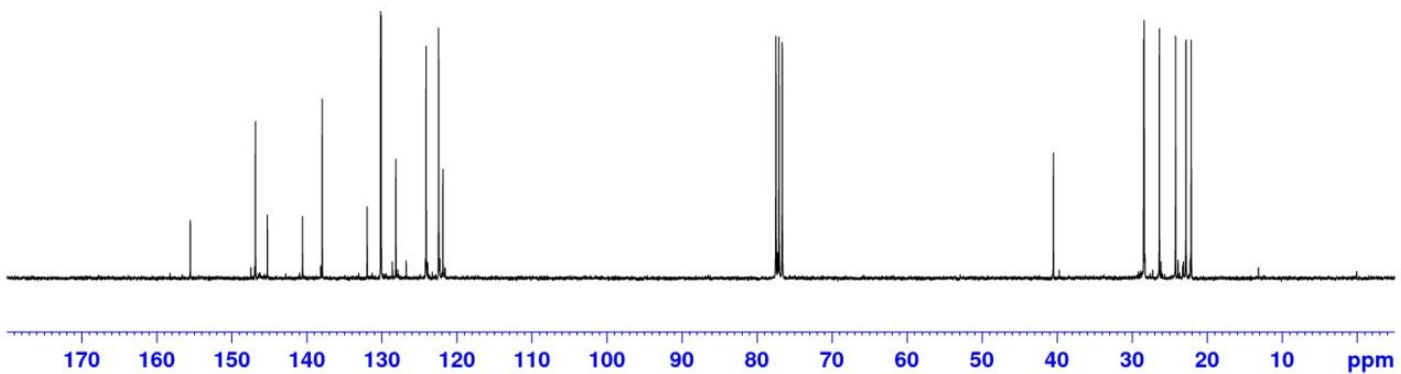

Figure S2. ${ }^{13} \mathrm{C}\left\{{ }^{1} \mathrm{H}\right\}$ NMR spectrum of $\mathbf{2}^{\mathrm{Dip}}$ in $\mathrm{CDCl}_{3}$ at room temperature. 


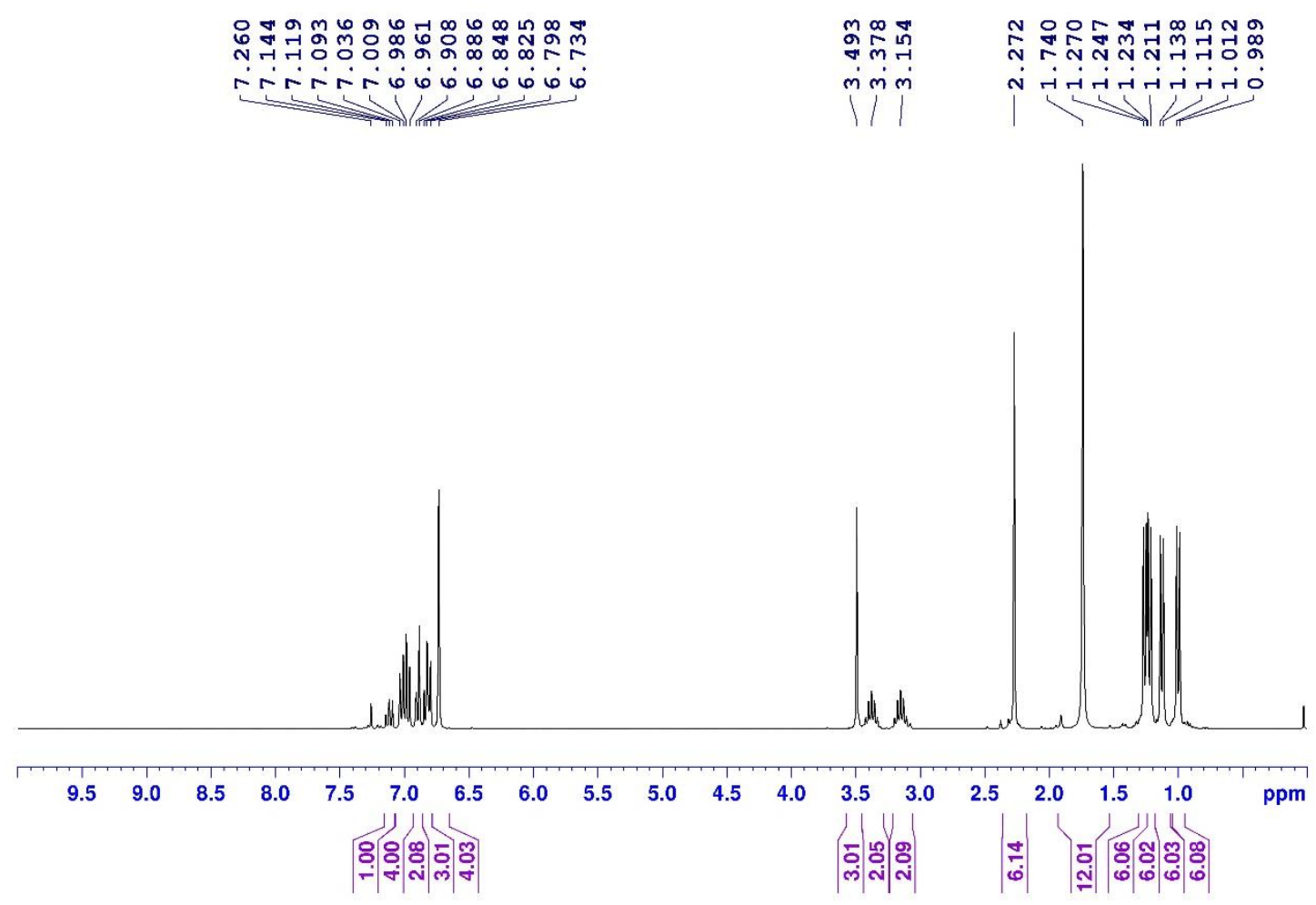

Figure S3. ${ }^{1} \mathrm{H}$ NMR spectrum of $3^{\text {Dip }}$ in $\mathrm{CDCl}_{3}$ at room temperature.
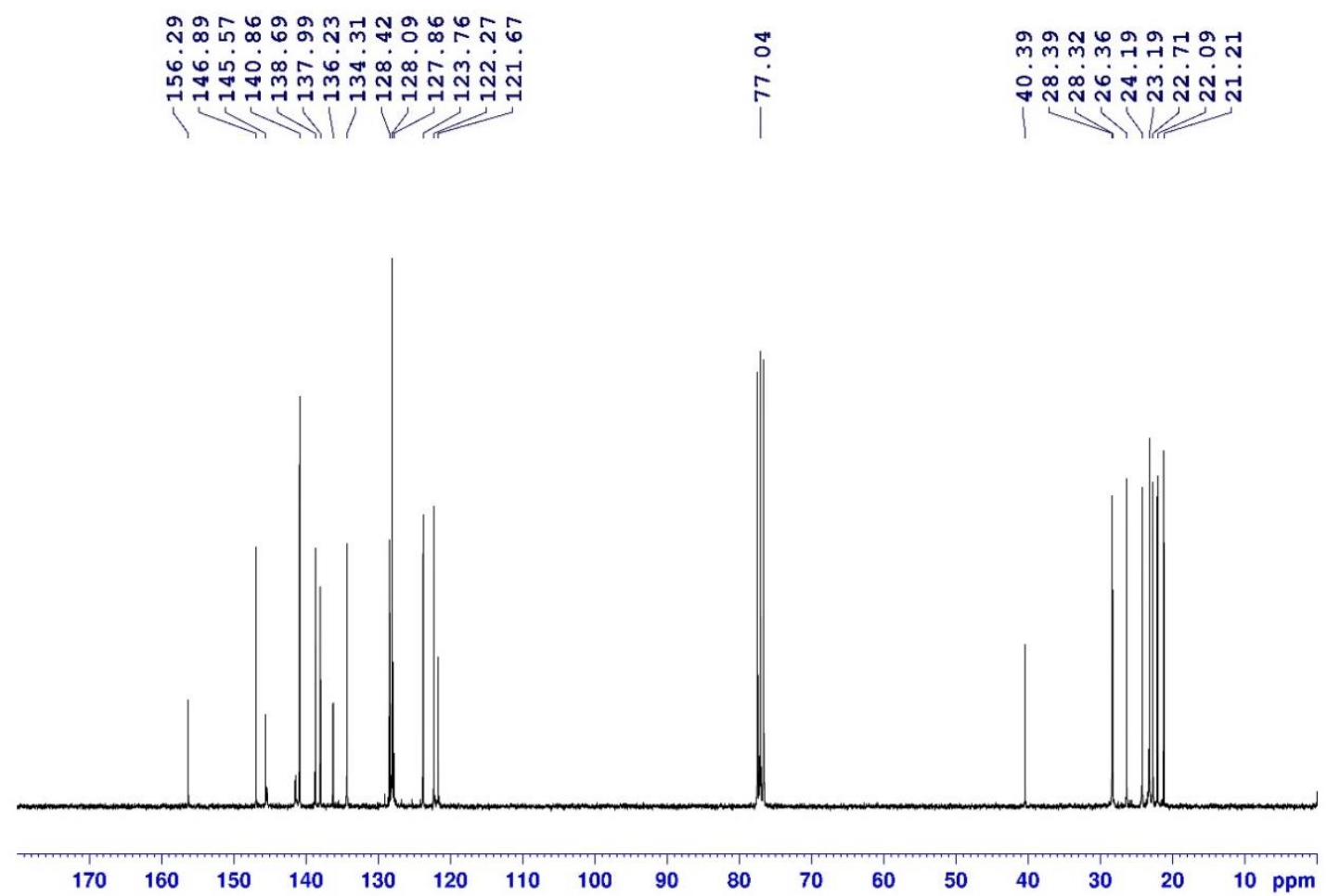

Figure S4. ${ }^{13} \mathrm{C}\left\{{ }^{1} \mathrm{H}\right\}$ NMR spectrum of $3^{\text {Dip }}$ in $\mathrm{CDCl}_{3}$ at room temperature. 


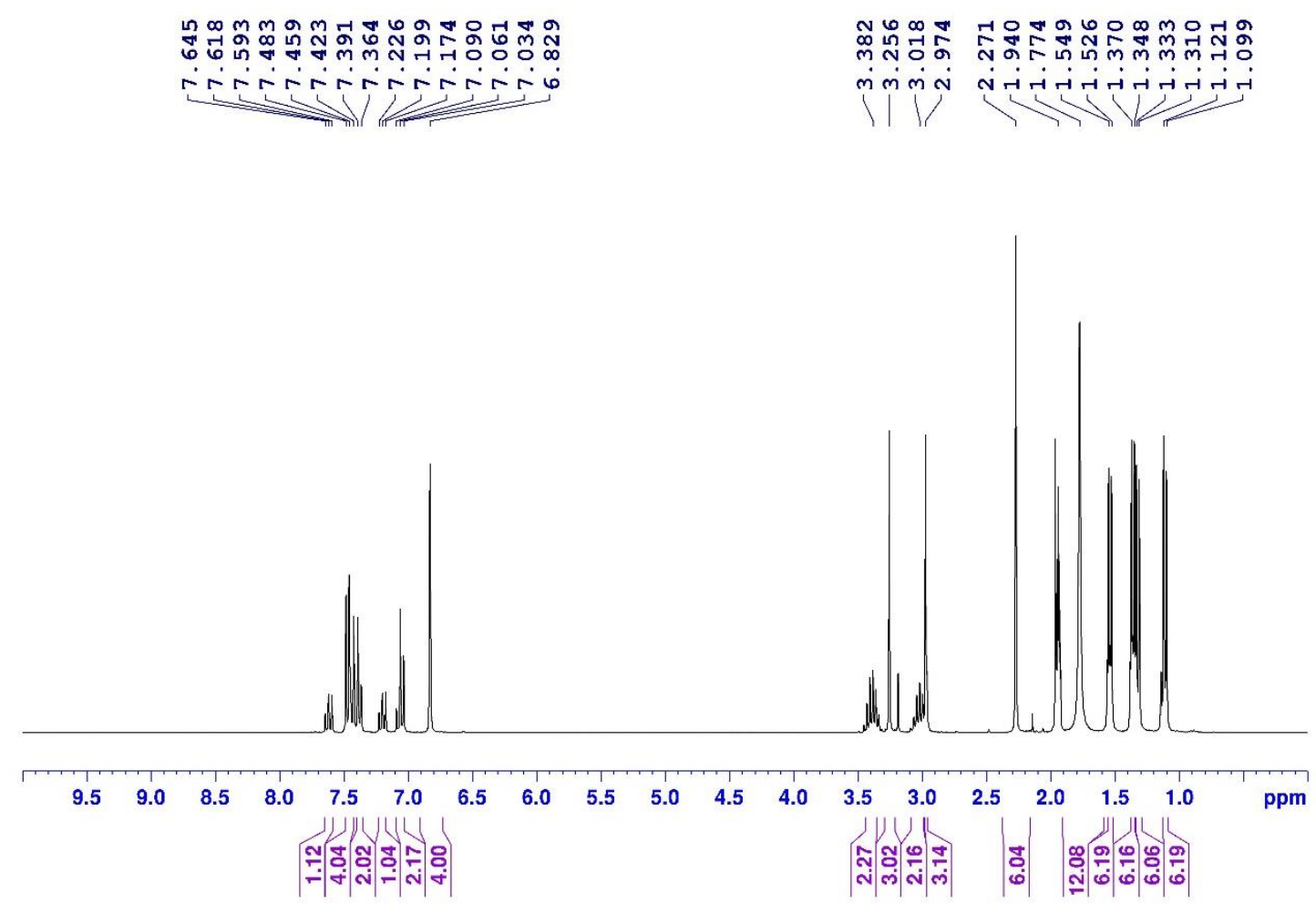

Figure S5. ${ }^{1} \mathrm{H}$ NMR spectrum of $4^{\text {Dip }}$ in $\mathrm{CD}_{3} \mathrm{CN}$ at room temperature.

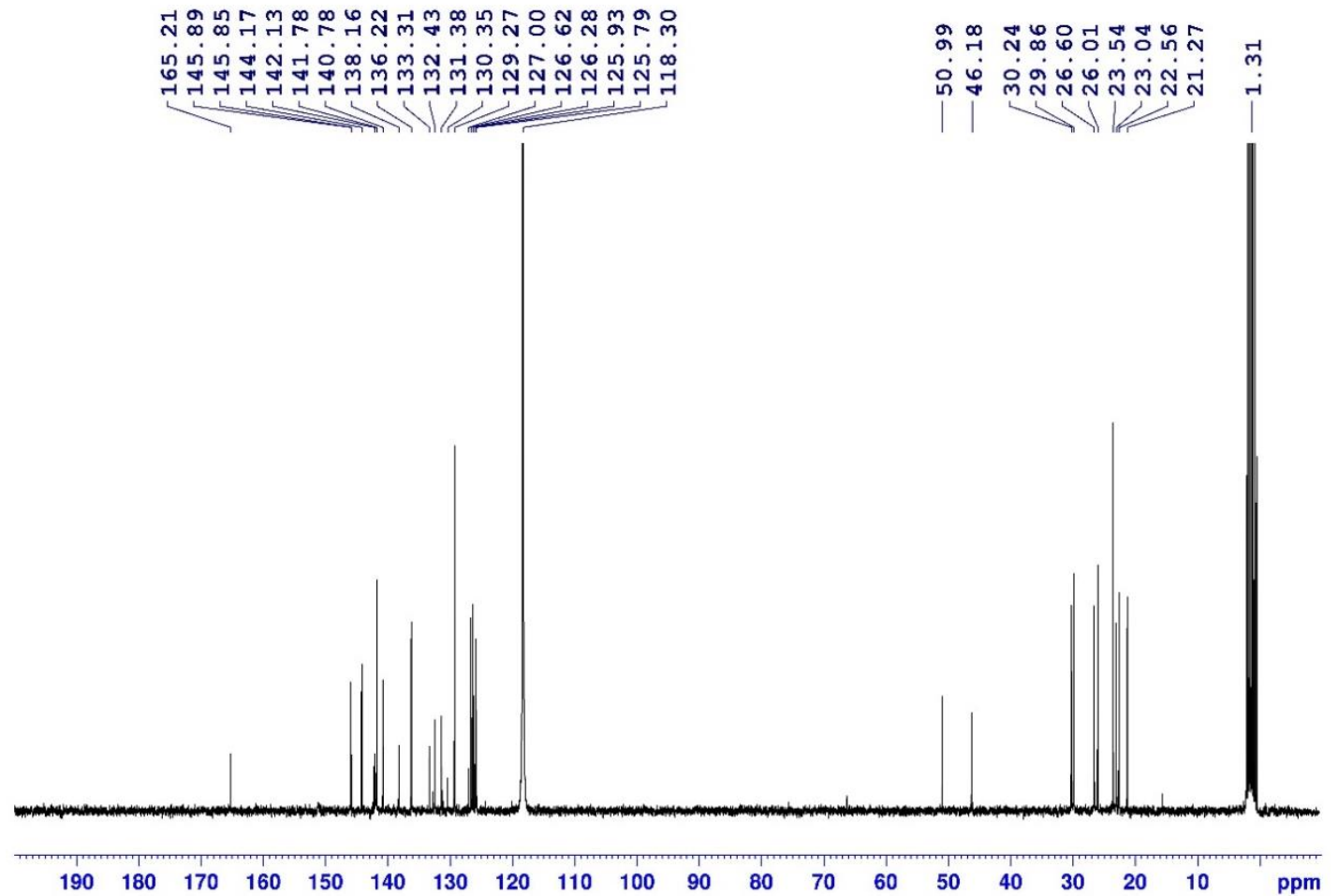

Figure S6. ${ }^{13} \mathrm{C}\left\{{ }^{1} \mathrm{H}\right\}$ NMR spectrum of $4^{\mathrm{Dip}}$ in $\mathrm{CD}_{3} \mathrm{CN}$ at room temperature. 


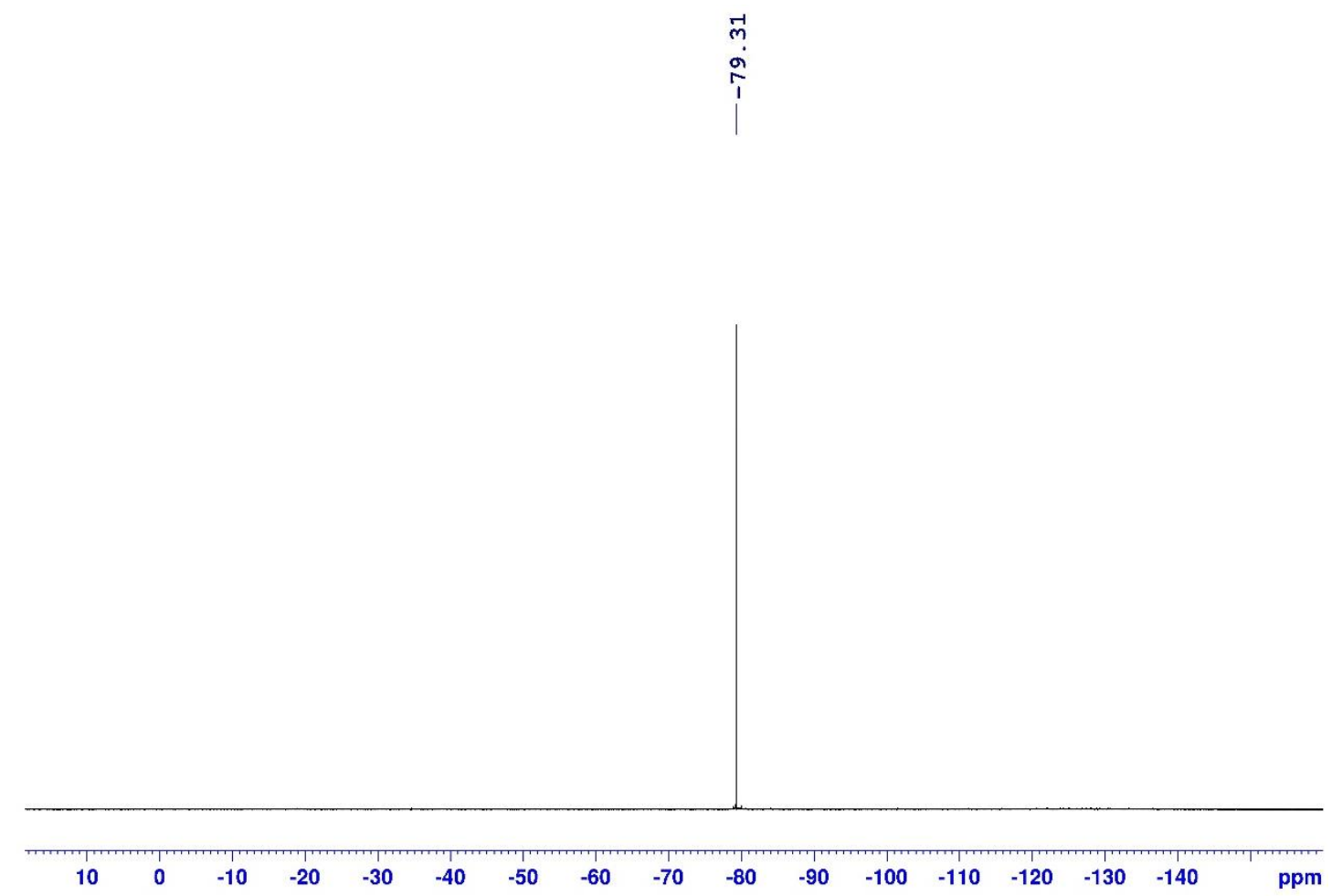

Figure S7. ${ }^{19} \mathrm{~F}\left\{{ }^{1} \mathrm{H}\right\}$ NMR spectrum of $4^{\text {Dip }}$ in $\mathrm{CD}_{3} \mathrm{CN}$ at room temperature.

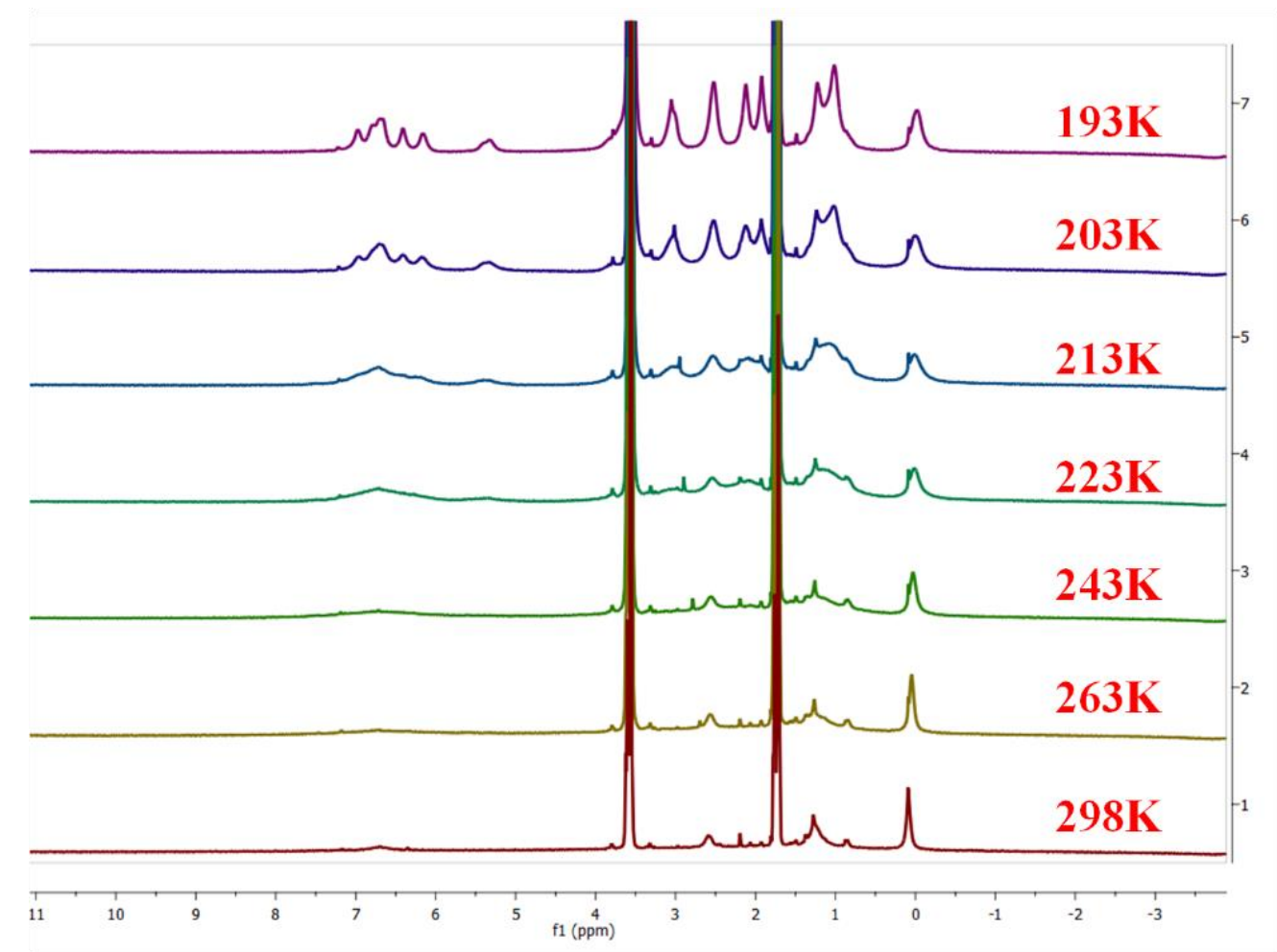

Figure S8. ${ }^{1} \mathrm{H}$ NMR spectra of $5^{\text {Dip }}$ in THF-d8 at variable temperature. 


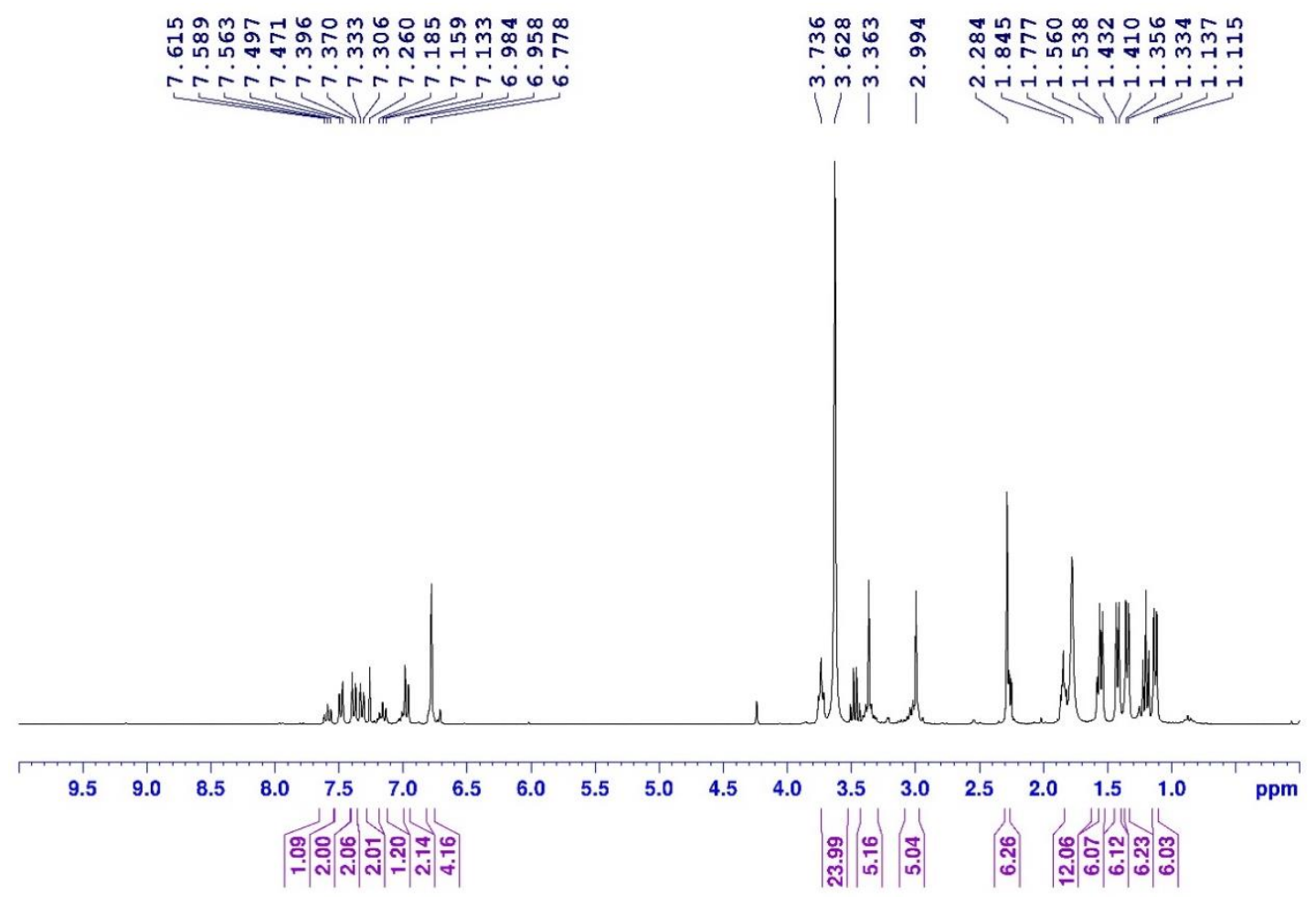

Figure S9. ${ }^{1} \mathrm{H}$ NMR spectrum of $4^{\mathrm{Dip}}$ in $\mathrm{CDCl}_{3}$ at room temperature after $1: 2$ reaction of $5^{\mathrm{Dip}}$ and AgOTf.

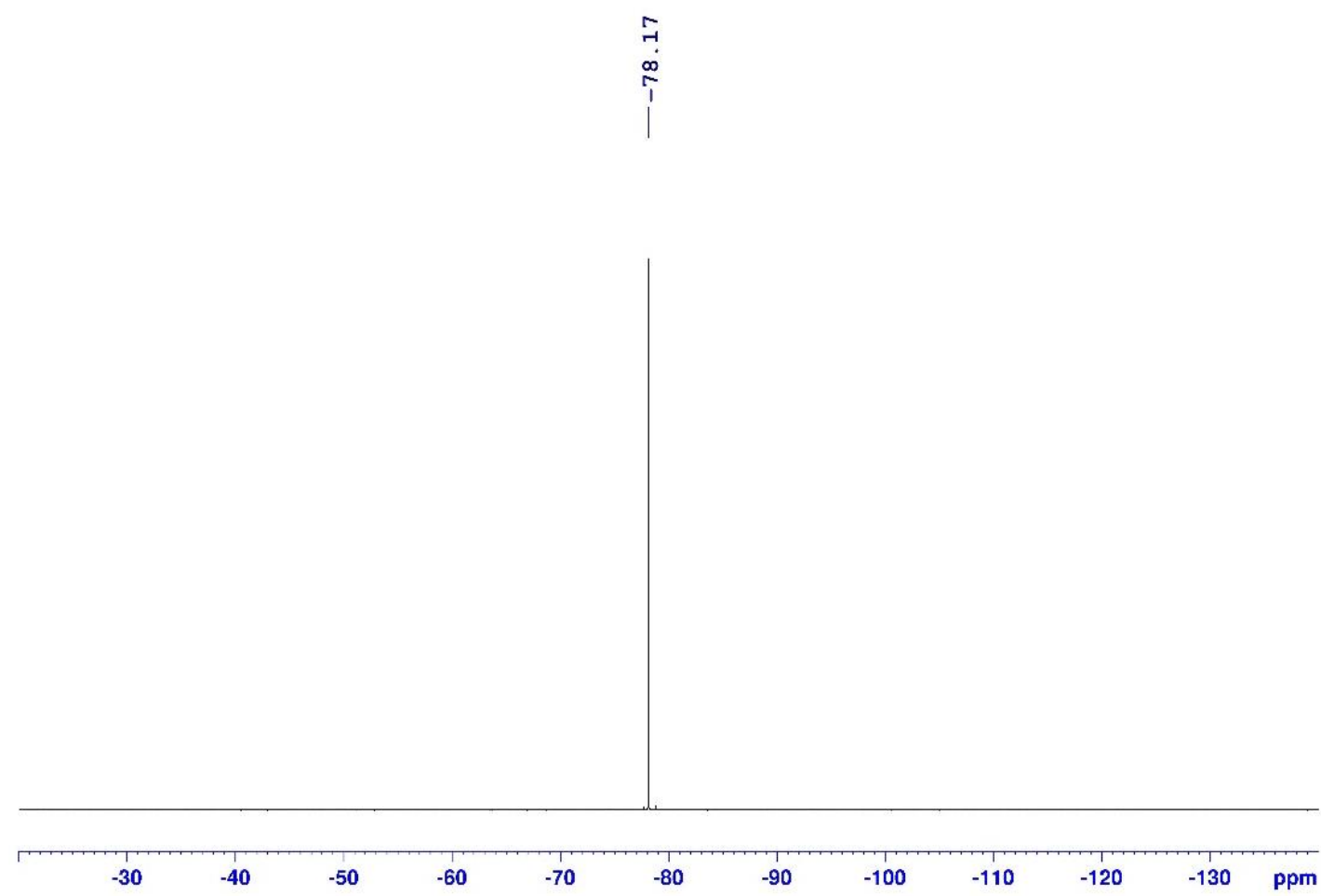

Figure S10. ${ }^{19} \mathrm{~F}$ NMR spectrum of $4^{\text {Dip }}$ in $\mathrm{CDCl}_{3}$ at room temperature after $1: 2$ reaction of $5^{\text {Dip }}$ and AgOTf. 


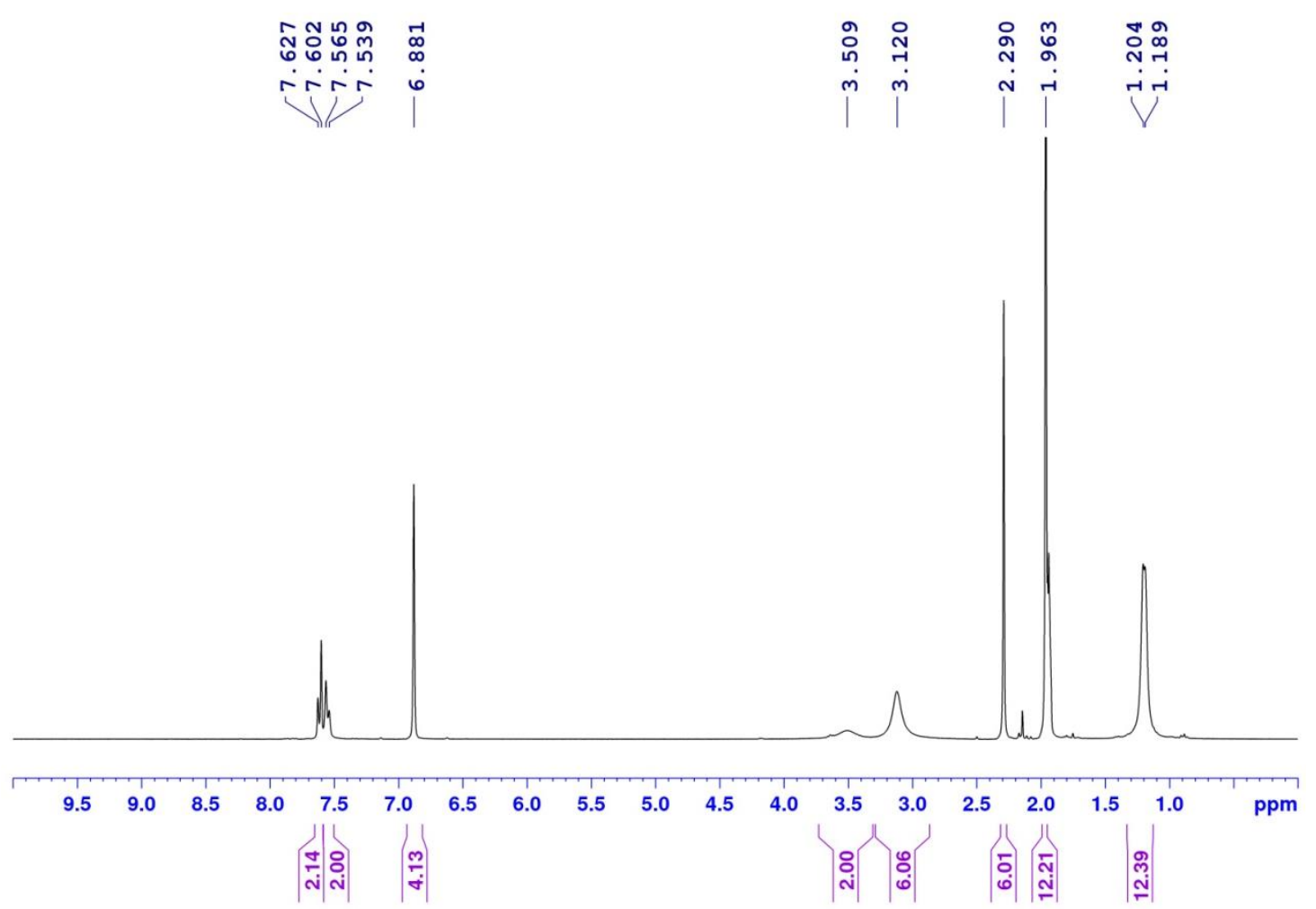

Figure S11. ${ }^{1} \mathrm{H}$ NMR spectrum of $4^{\text {ipr }}$ in $\mathrm{CD}_{3} \mathrm{CN}$ at room temperature.

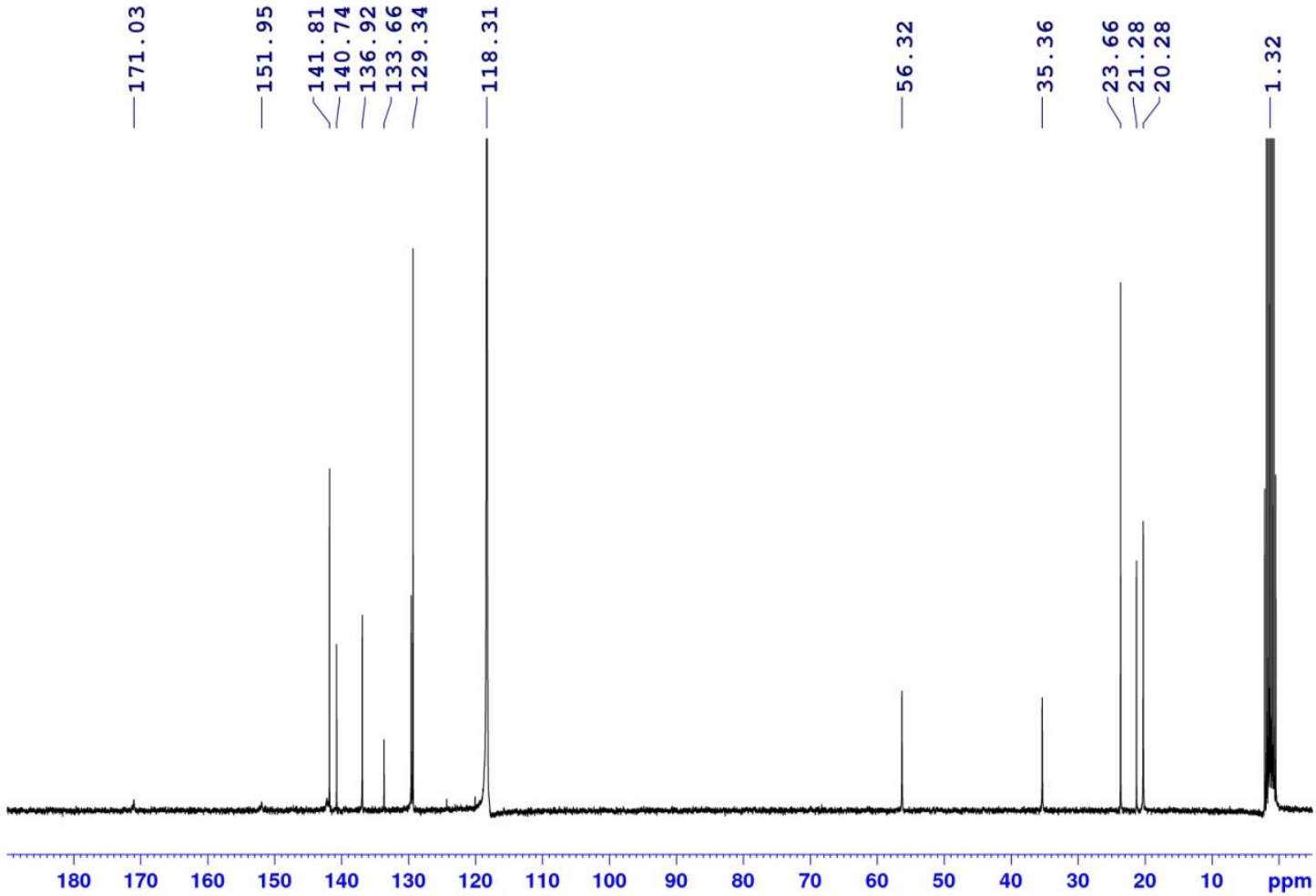

Figure S12. ${ }^{13} \mathrm{C}\left\{{ }^{1} \mathrm{H}\right\}$ NMR spectrum of $4^{\mathrm{iPr}}$ in $\mathrm{CD}_{3} \mathrm{CN}$ at room temperature. 


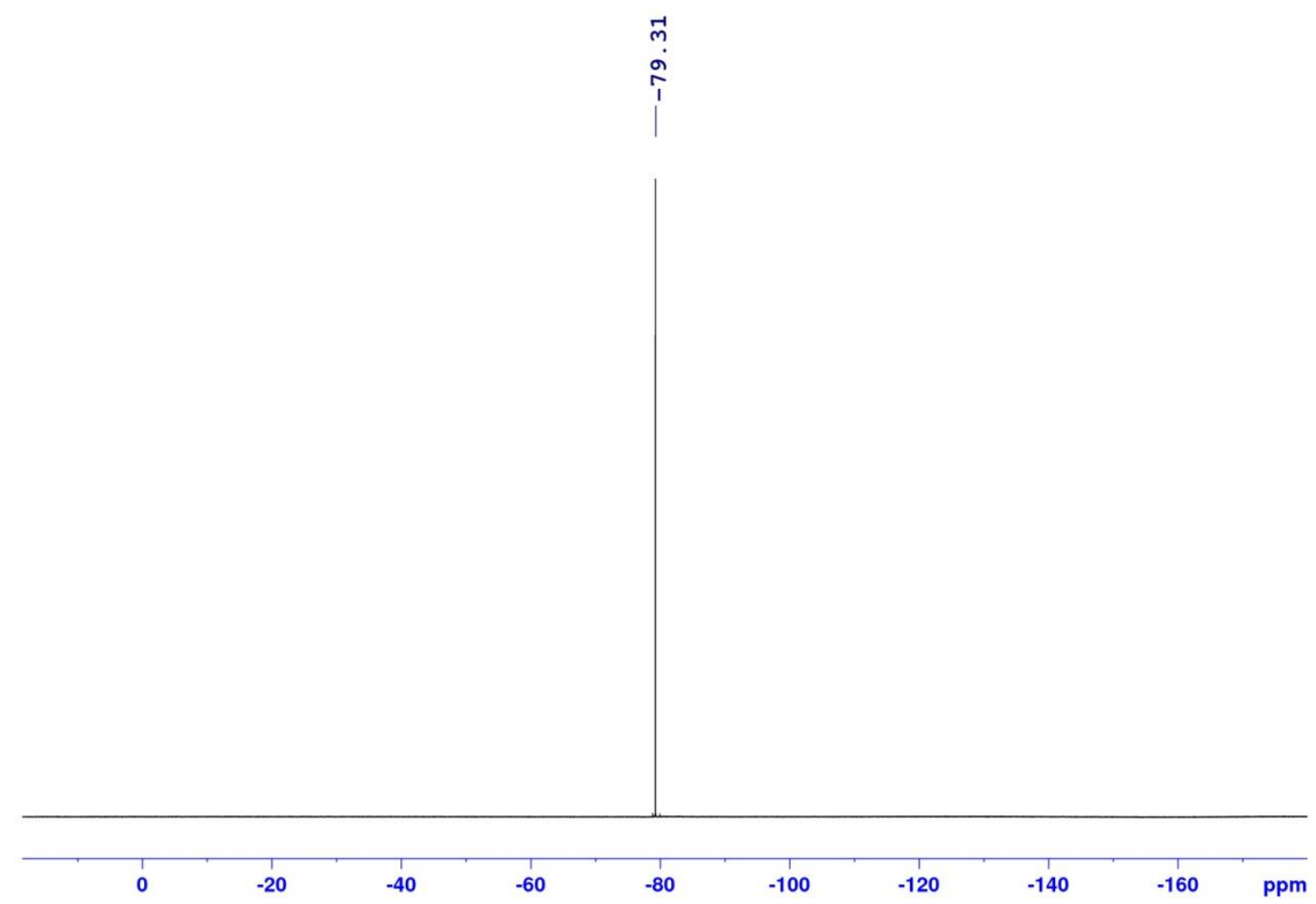

Figure S13. ${ }^{19} \mathrm{~F}\left\{{ }^{1} \mathrm{H}\right\}$ NMR spectrum of $4^{\text {iPr }}$ in $\mathrm{CD}_{3} \mathrm{CN}$ at room temperature.

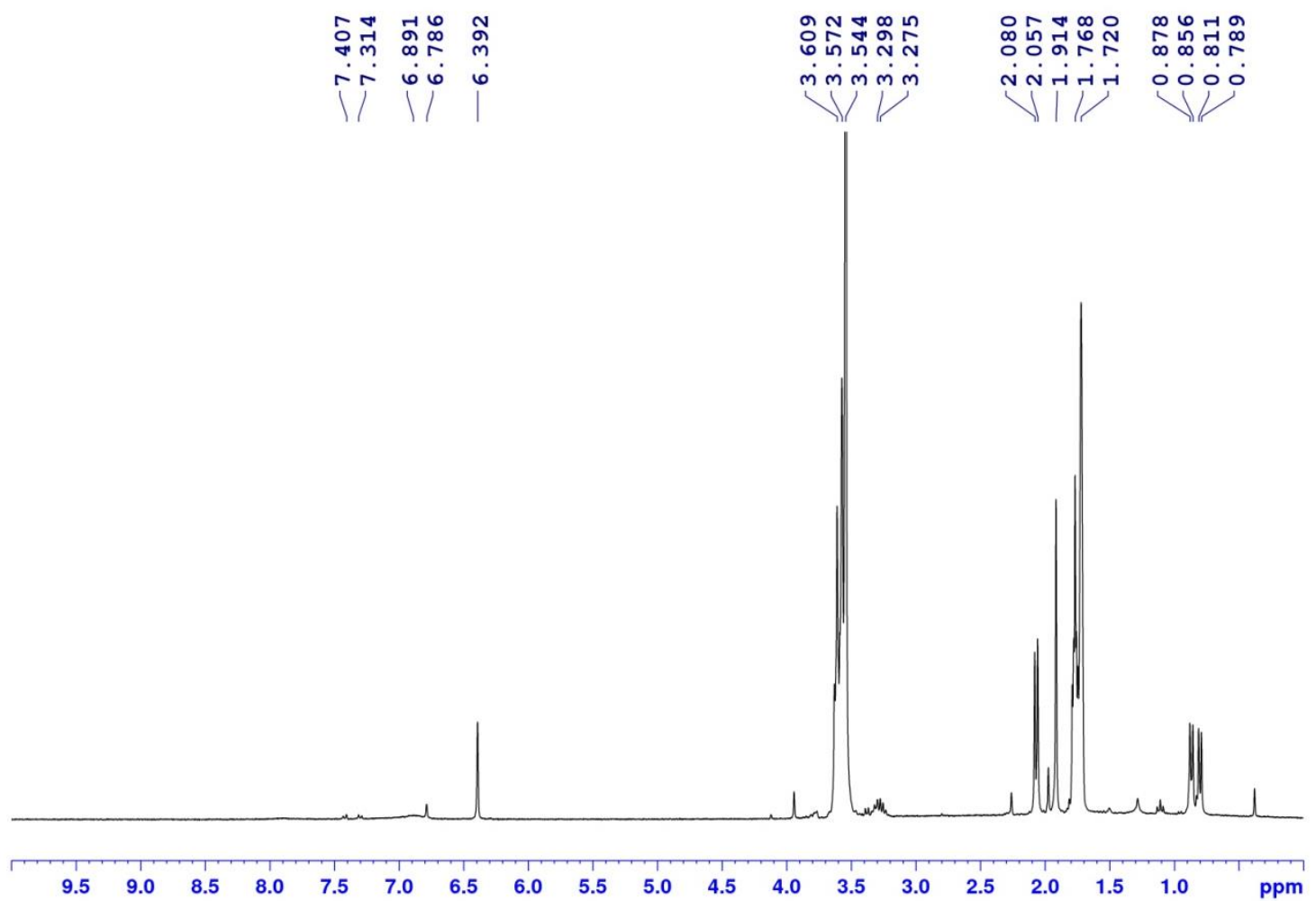

Figure S14. ${ }^{1} \mathrm{H}$ NMR spectrum of $5^{\text {iPr }}$ in THF-ds at room temperature. 


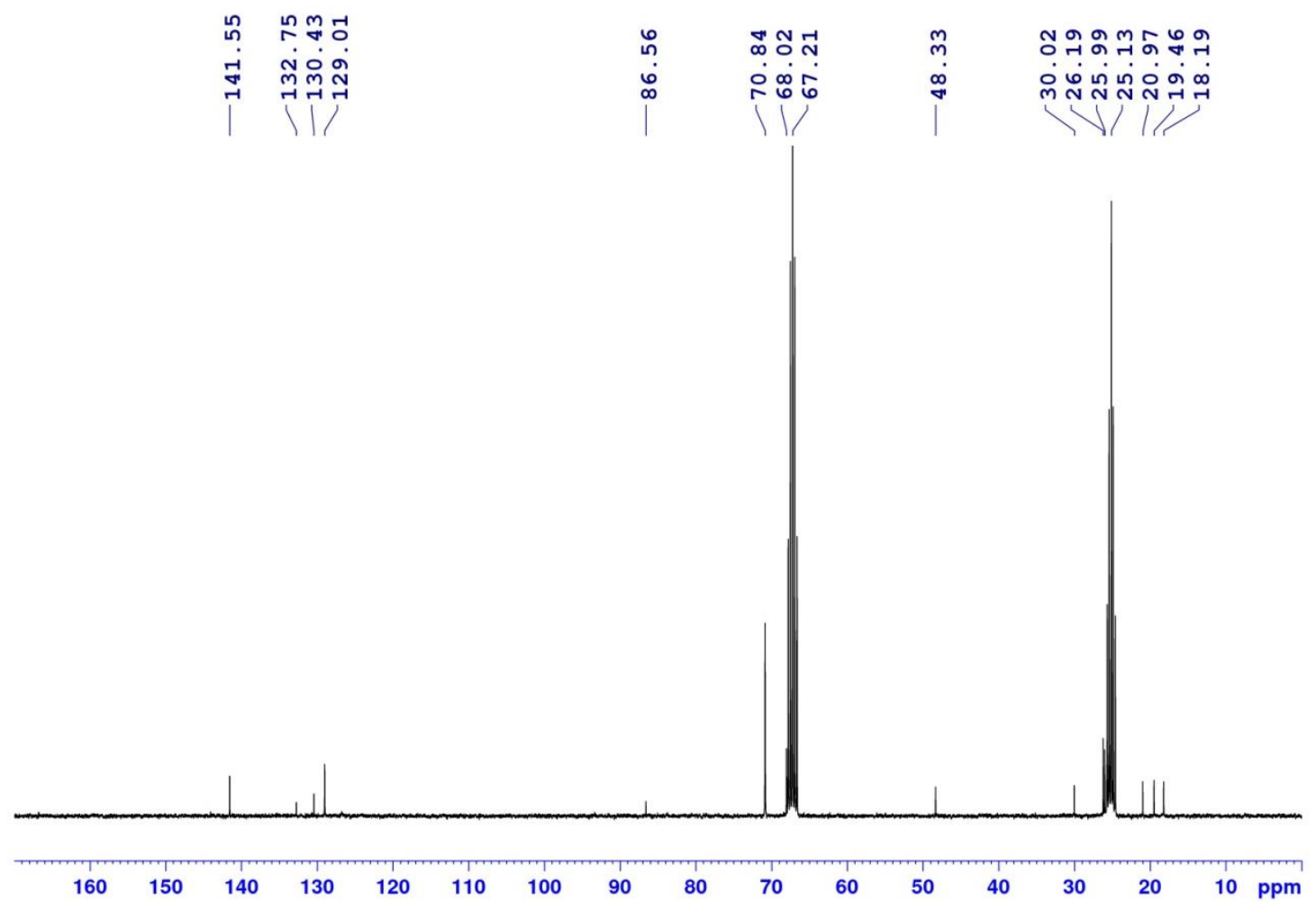

Figure S15. $\left.{ }^{13} \mathrm{C}^{\{1} \mathrm{H}\right\}$ NMR spectrum of $5^{\text {iPr }}$ in THF- $\mathrm{d}_{8}$ at room temperature.

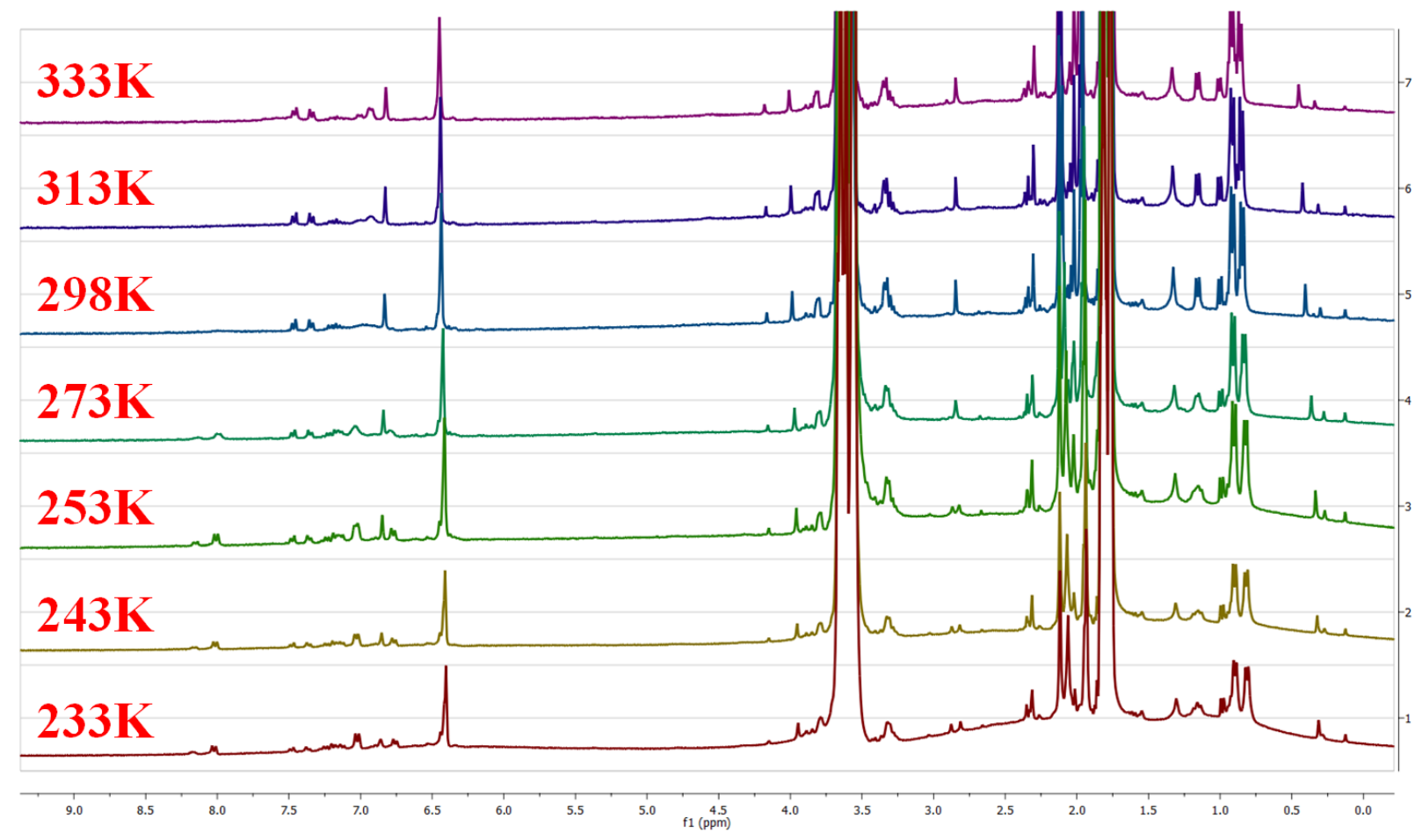

Figure S16. ${ }^{1} \mathrm{H}$ NMR spectra of $5^{i p r}$ in THF-d 8 at variable temperature. 


\section{UV/Vis/NIR Spectra}

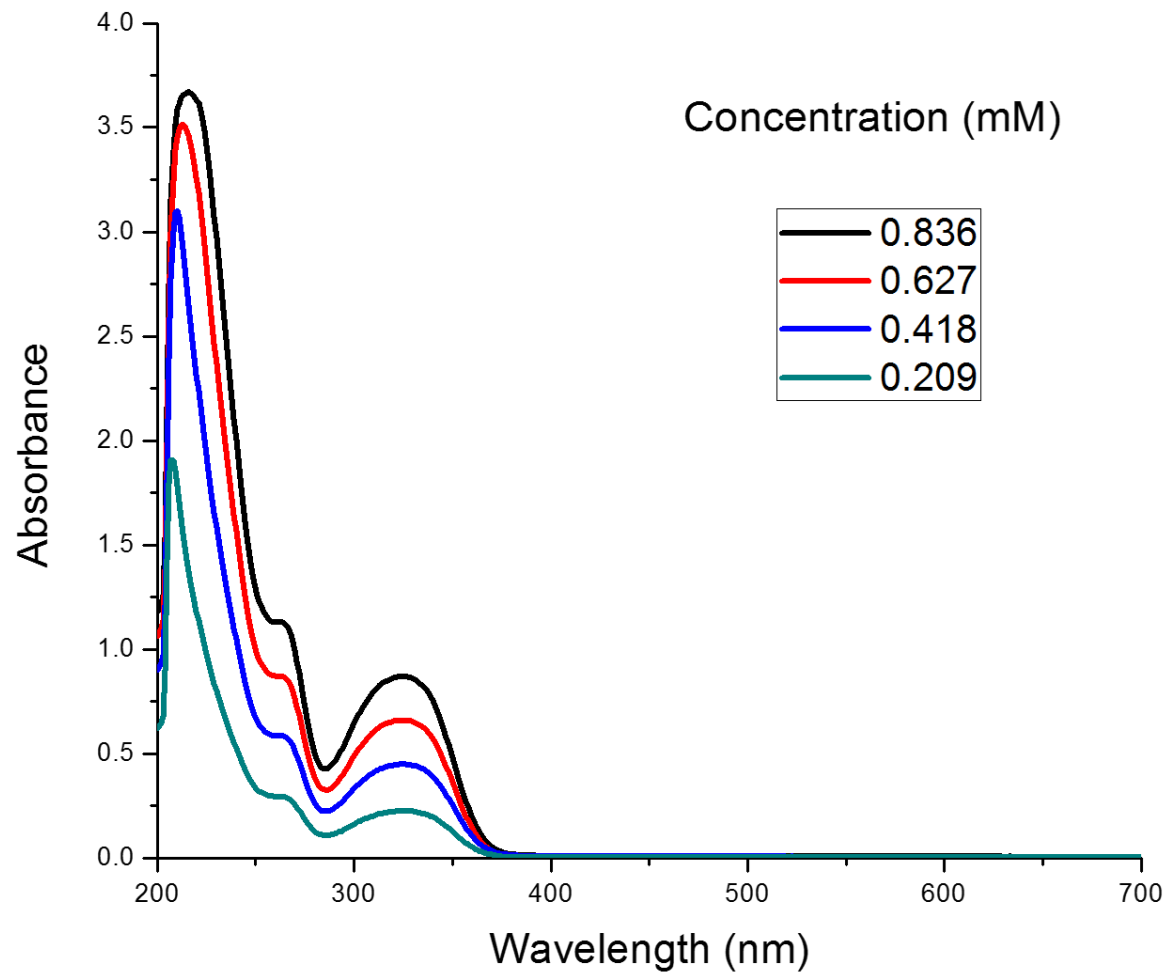

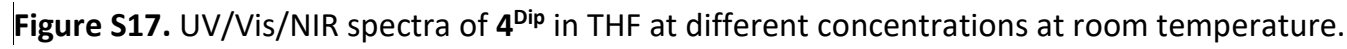

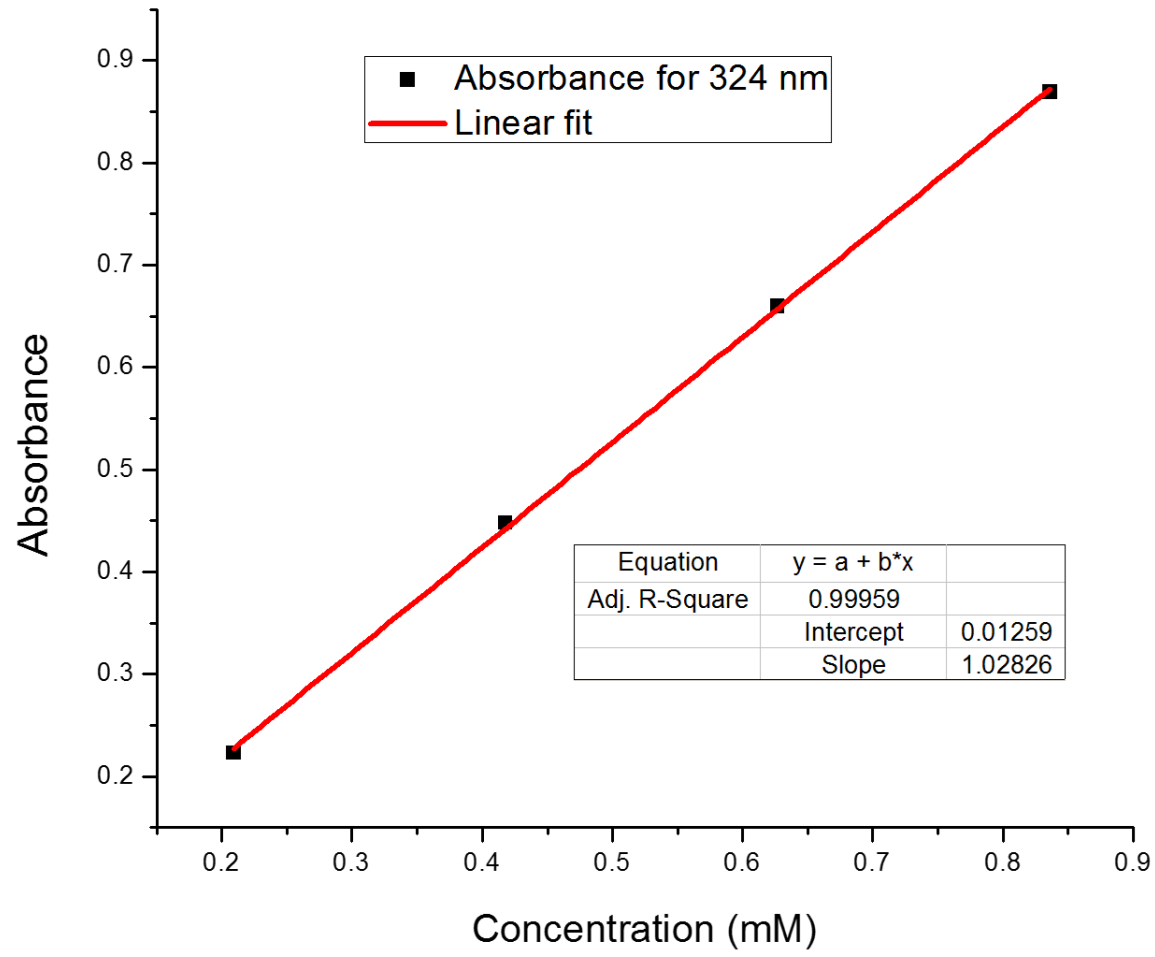

Figure S18. Linear regression of $4^{\text {Dip }}$ at $324 \mathrm{~nm}$. 


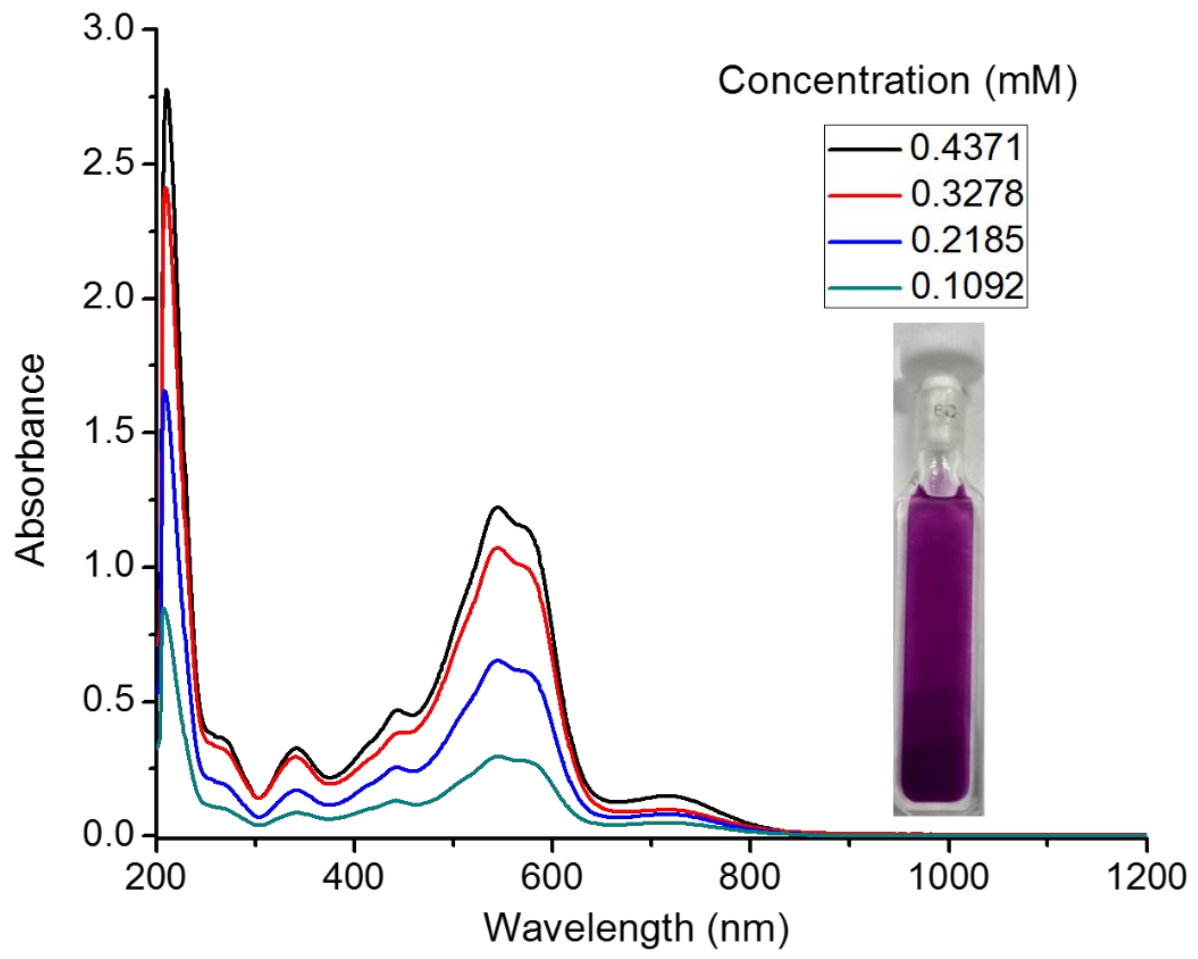

Figure S19. UV/Vis/NIR spectra of $5^{\text {Dip }}$ in THF at different concentrations at room temperature (absorbance at $\lambda_{\max }=$ $717 \mathrm{~nm}$ could be due to the formation of trace amount of $6^{\text {Dip }}$ during sample preparation by the contamination with adventitious source of oxygen).

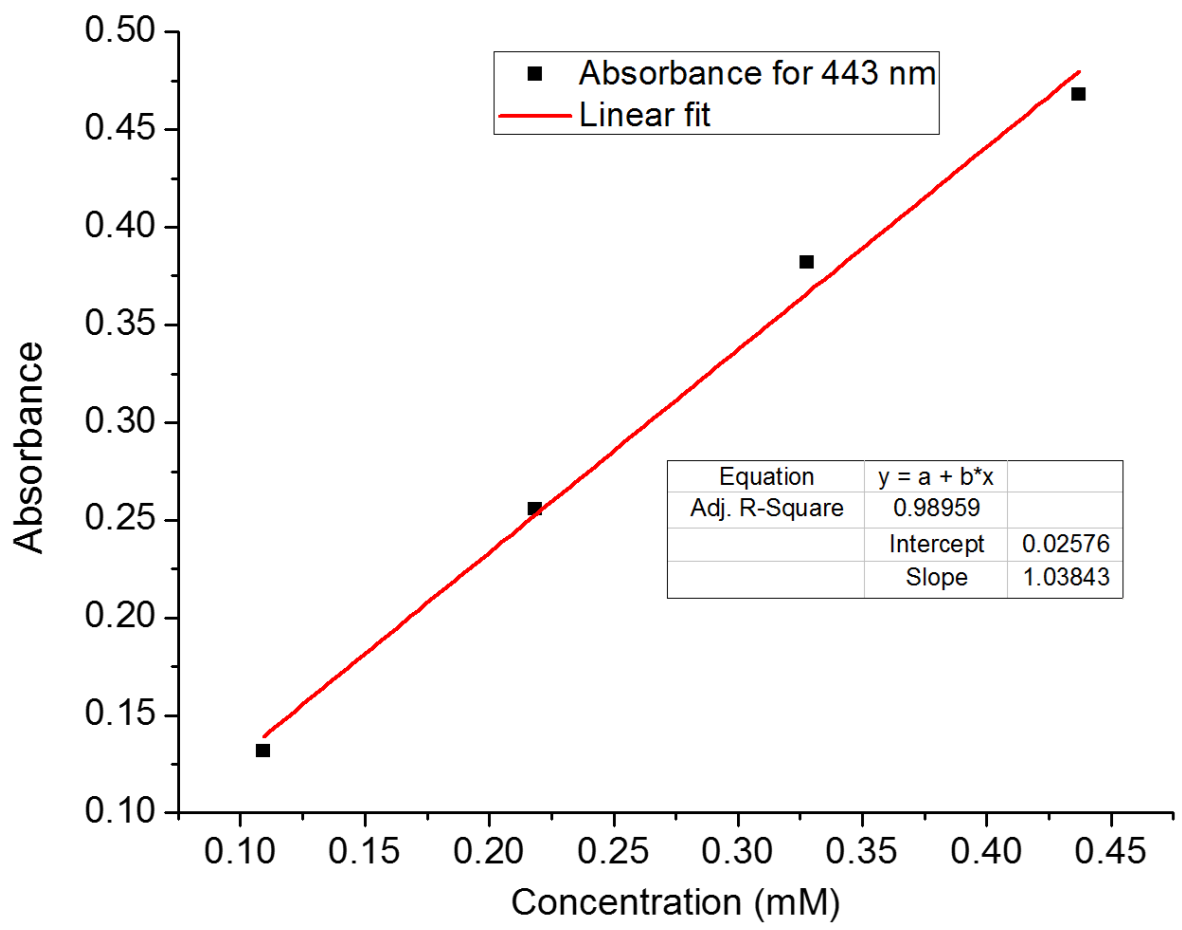

Figure S20. Linear regression of $5^{\text {Dip }}$ at $443 \mathrm{~nm}$. 


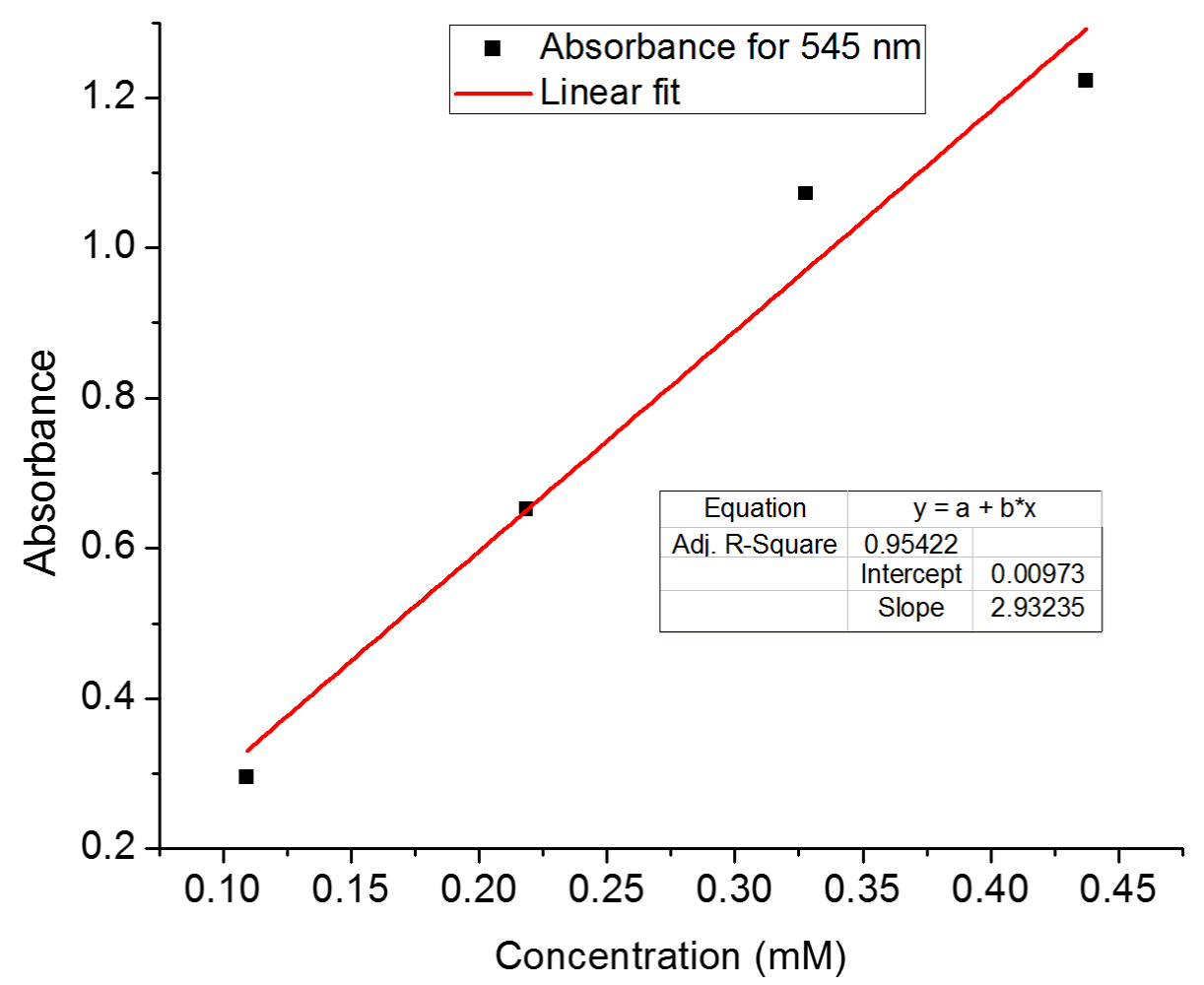

Figure S21. Linear regression of $5^{\text {Dip }}$ at $545 \mathrm{~nm}$.

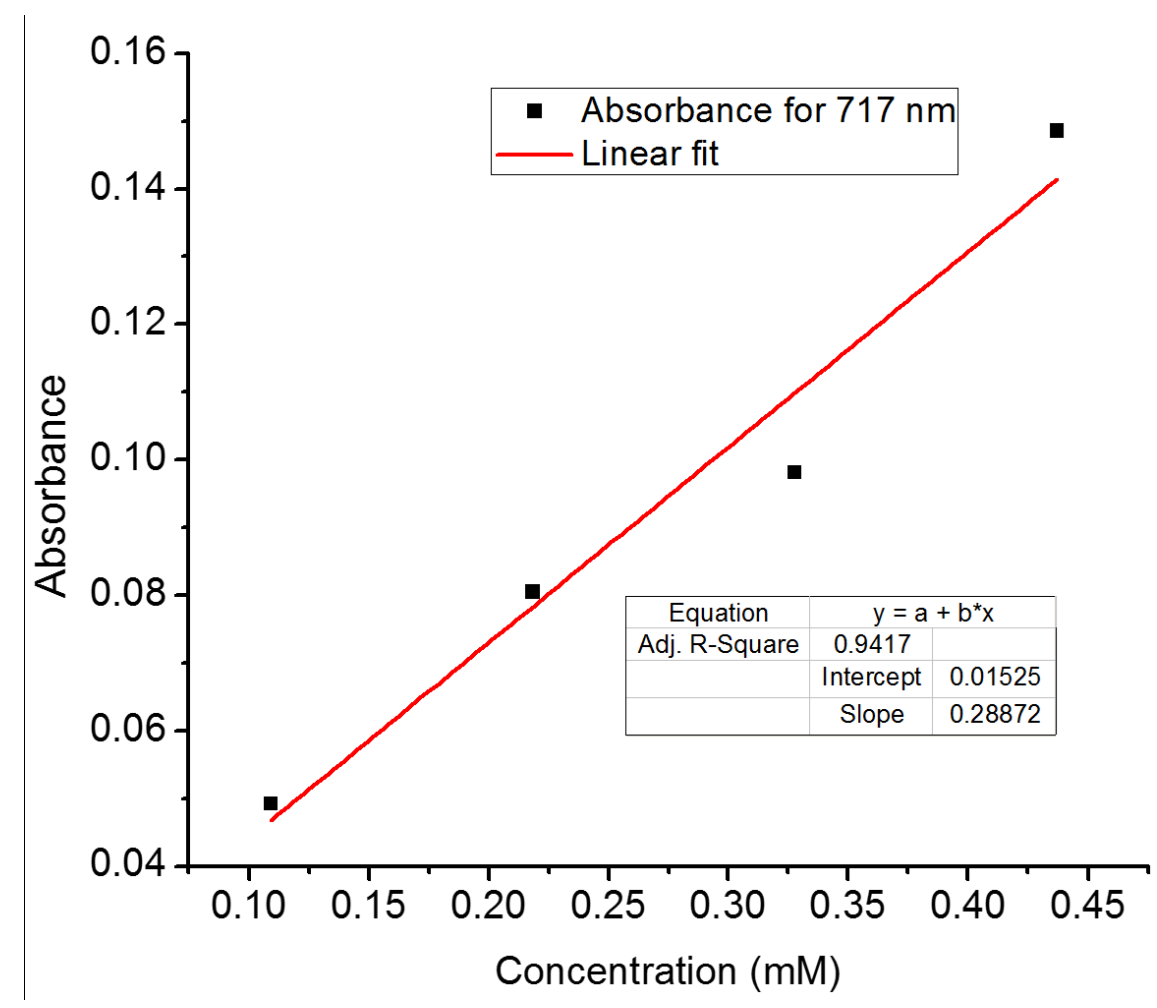

Figure S22. Linear regression of $5^{\text {Dip }}$ at $717 \mathrm{~nm}$. 


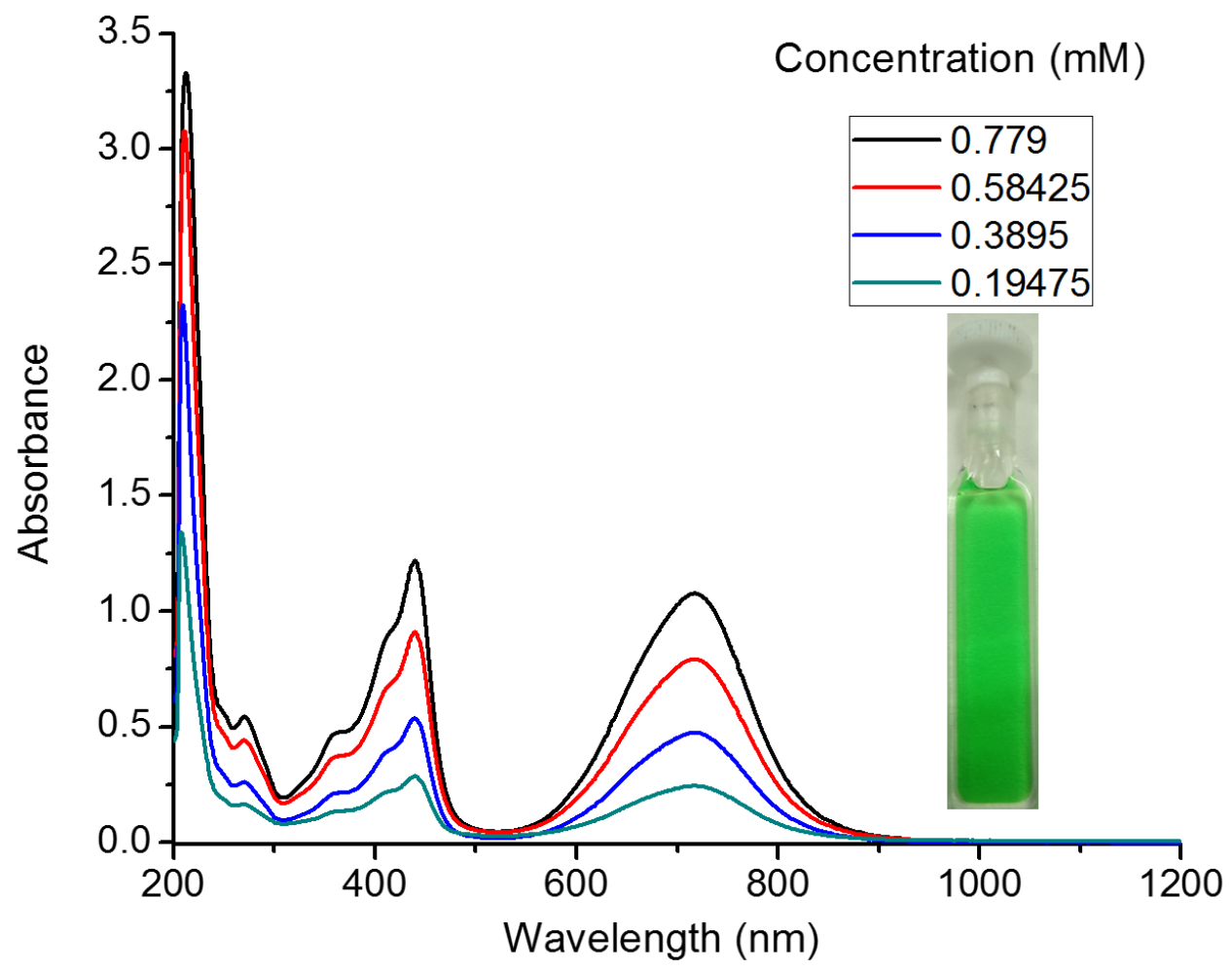

Figure S23. UV/Vis/NIR spectra of $6^{\text {Dip }}$ in THF at different concentrations at room temperature.

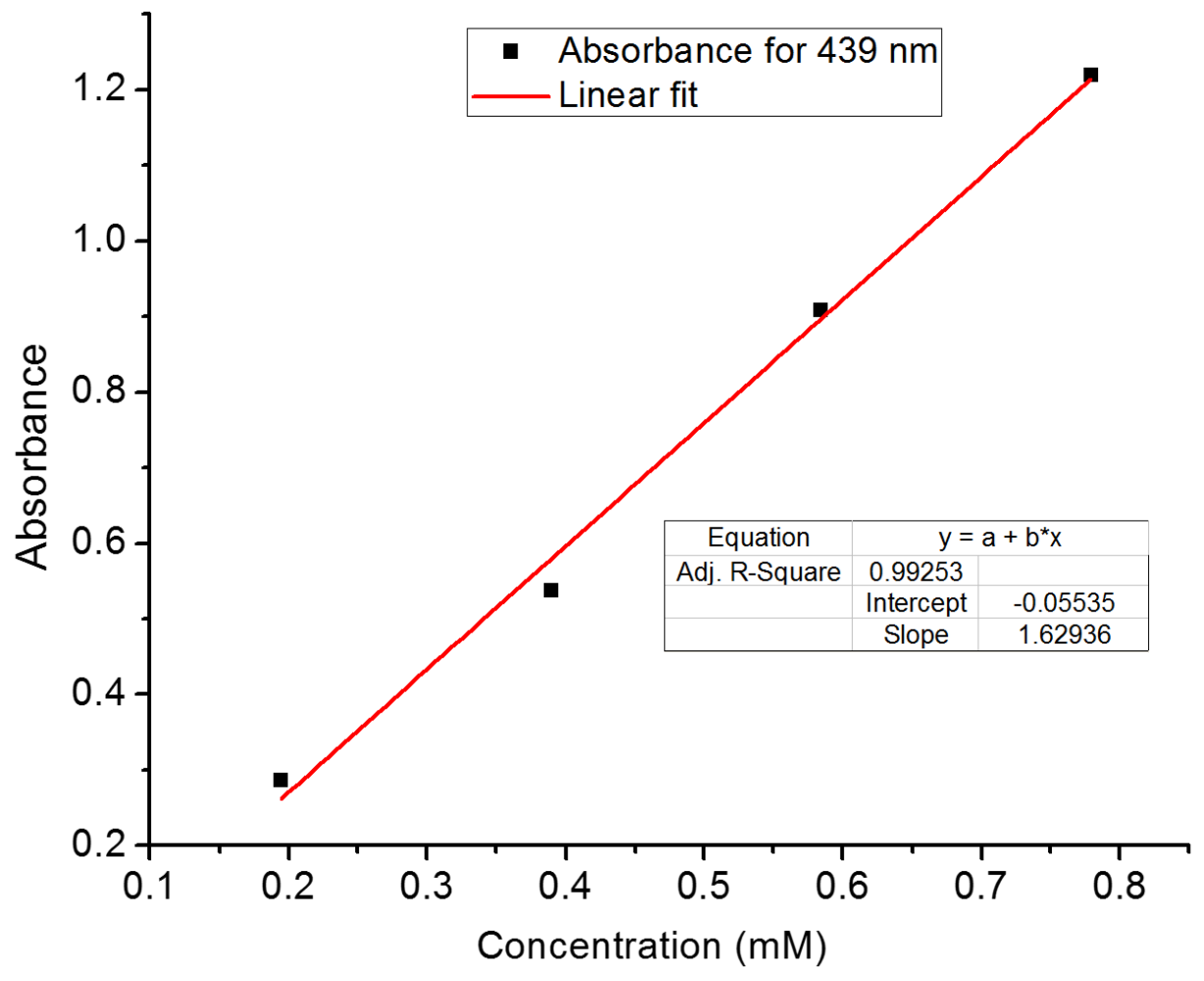

Figure S24. Linear regression of $6^{\text {Dip }}$ at $439 \mathrm{~nm}$. 


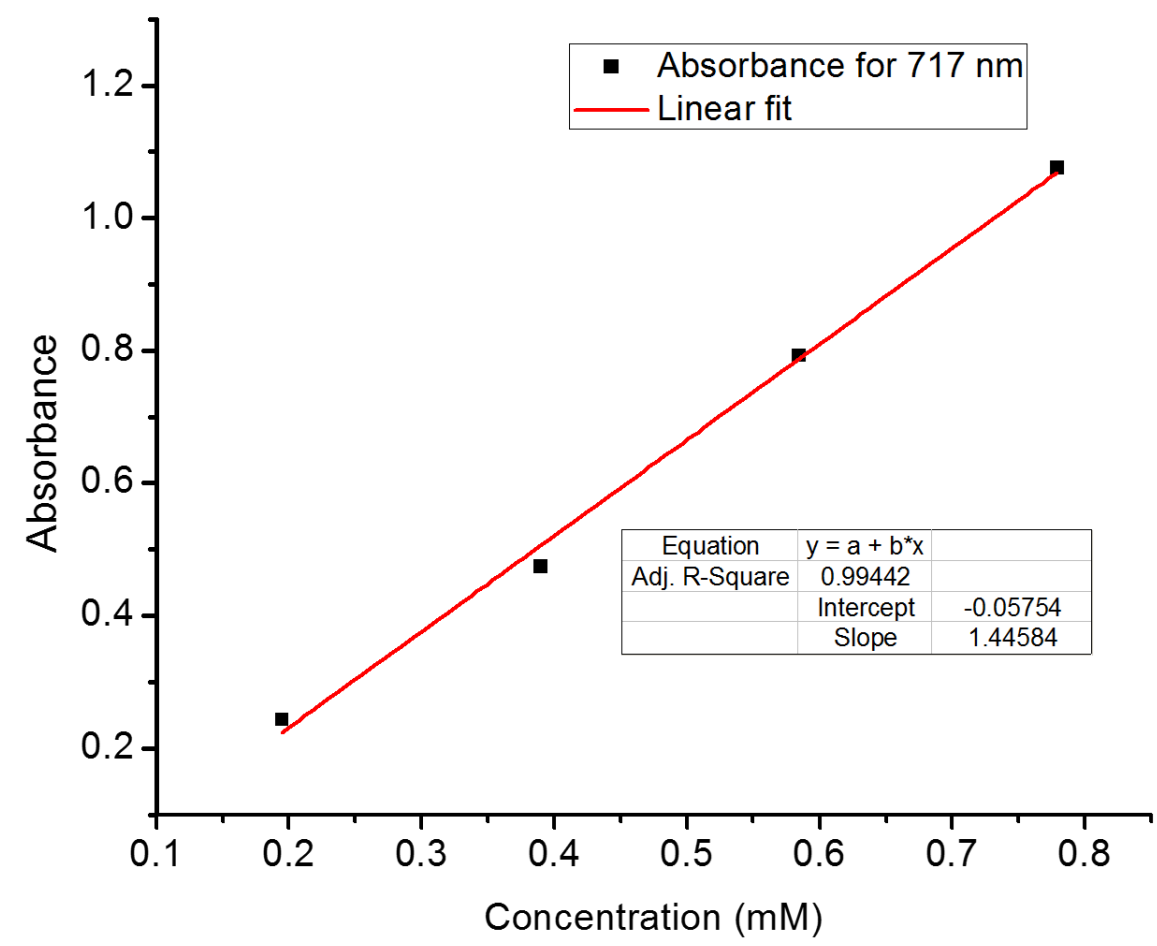

Figure S25. Linear regression of $6^{\text {Dip }}$ at $717 \mathrm{~nm}$.

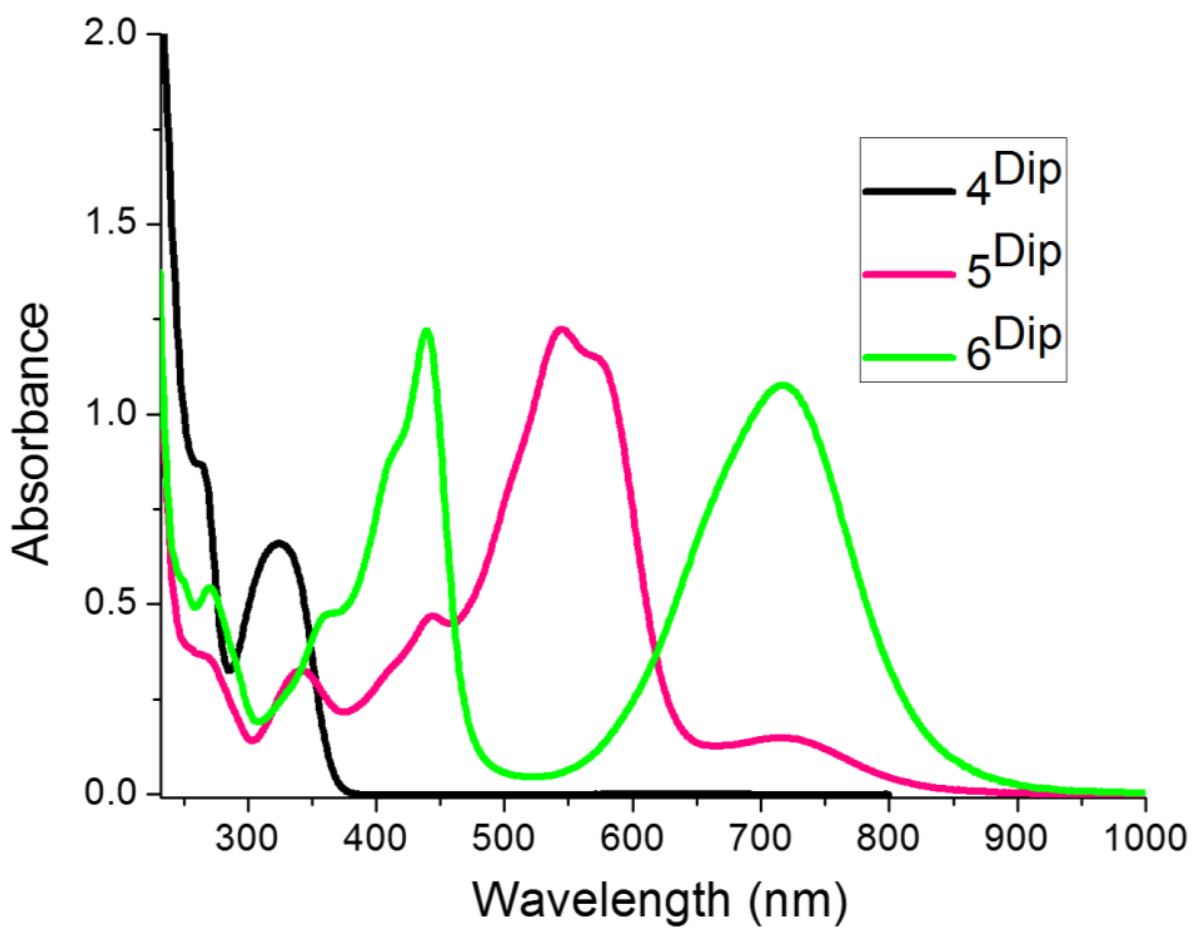

Figure S26. Comparison of UV/Vis/NIR spectra of $4^{\text {Dip }}, 5^{\text {Dip }}$, and $\mathbf{6}^{\text {Dip }}$ in THF at room temperature (absorbance at $\lambda_{\text {max }}$ $=717 \mathrm{~nm}$ could be due to the formation of trace amount of $6^{\text {Dip }}$ during sample preparation by the contamination with adventitious source of oxygen). 


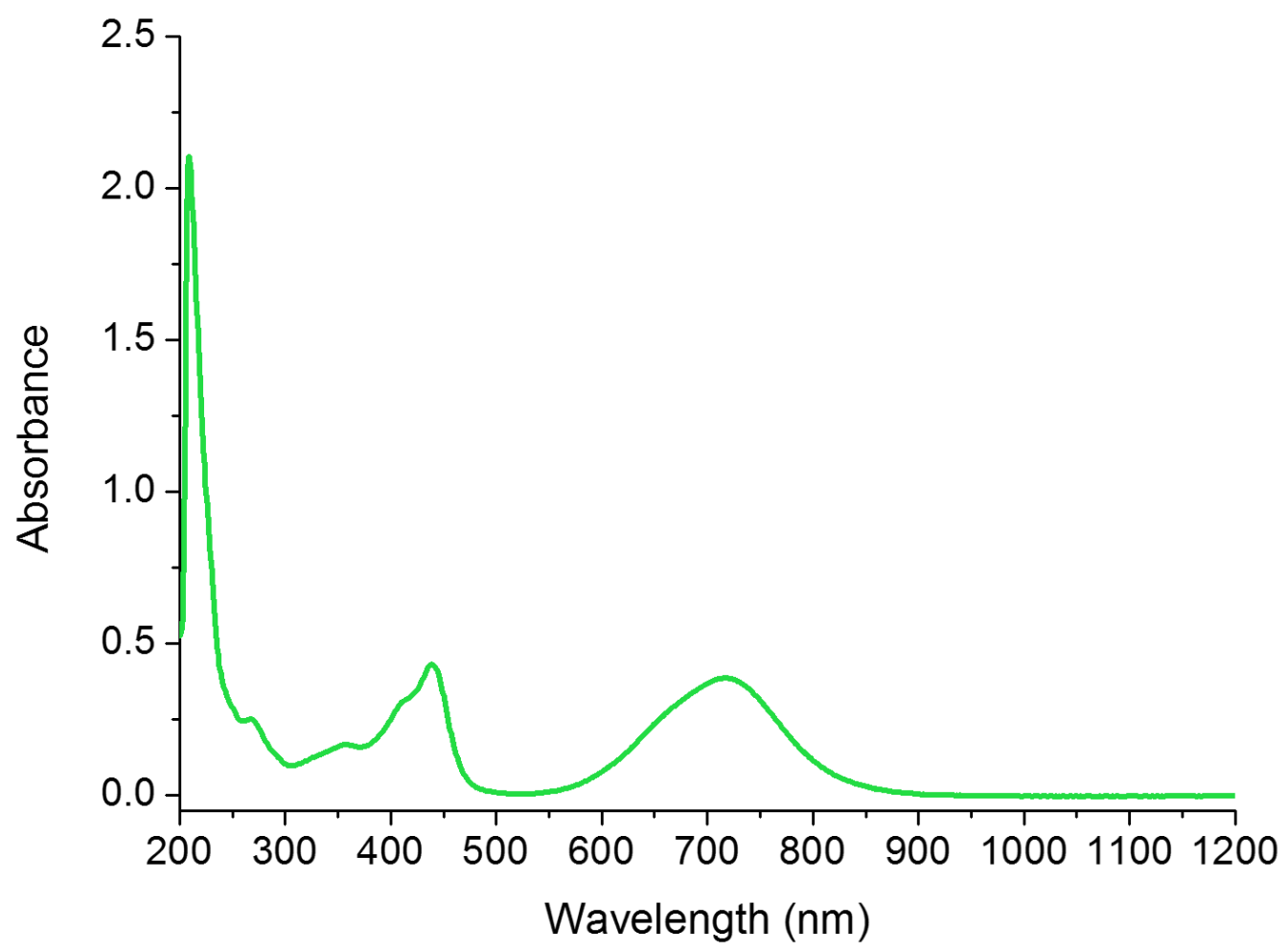

Figure S27. UV/Vis/NIR spectra of $6^{\text {Dip }}$ in THF at room temperature after 1:1 reaction of $5^{\text {Dip }}$ and $4^{\text {Dip }}$.

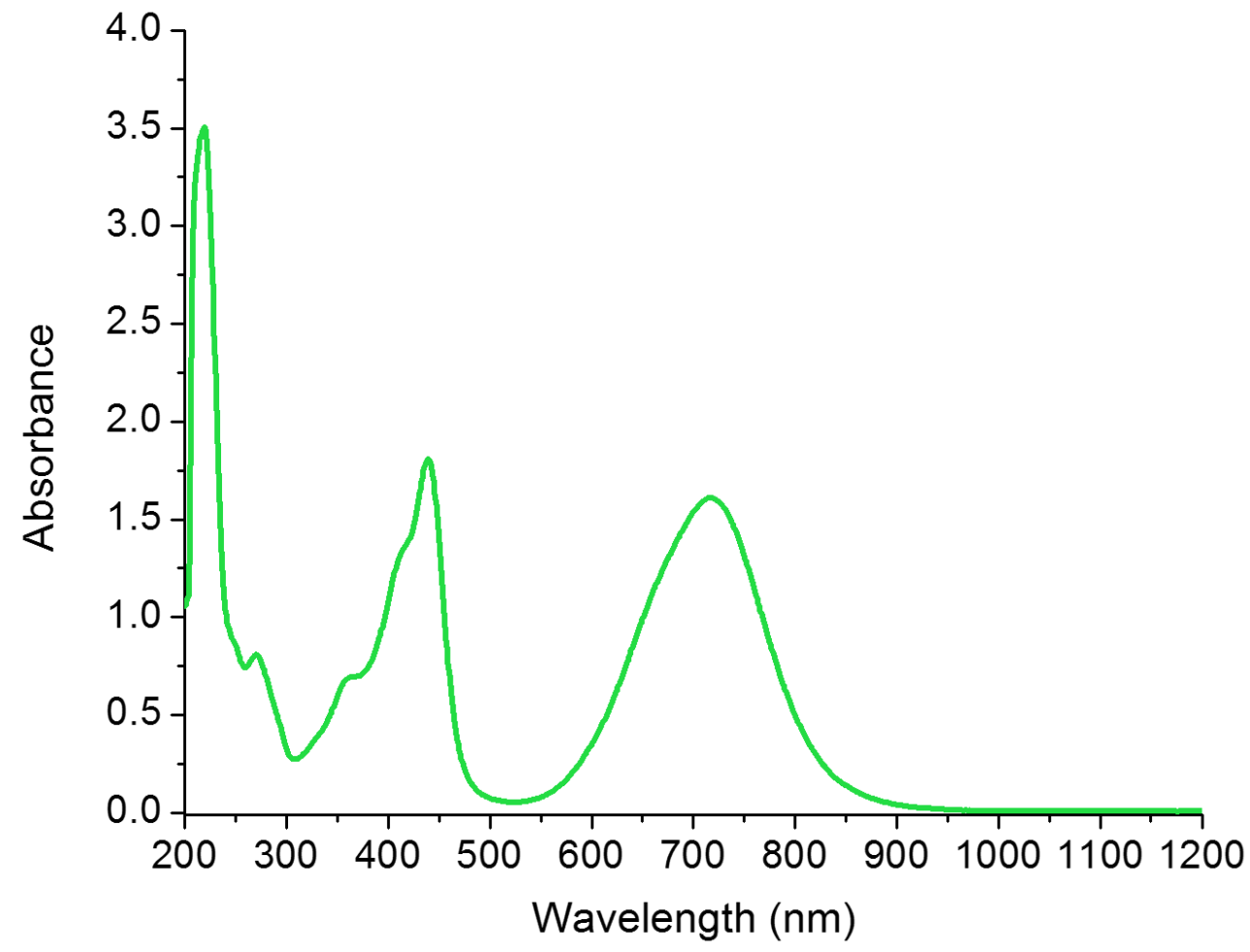

Figure S28. UV/Vis/NIR spectra of $\mathbf{6}^{\text {Dip }}$ in THF at room temperature after 1:1 reaction of $\mathbf{5}^{\text {Dip }}$ and AgOTf. 


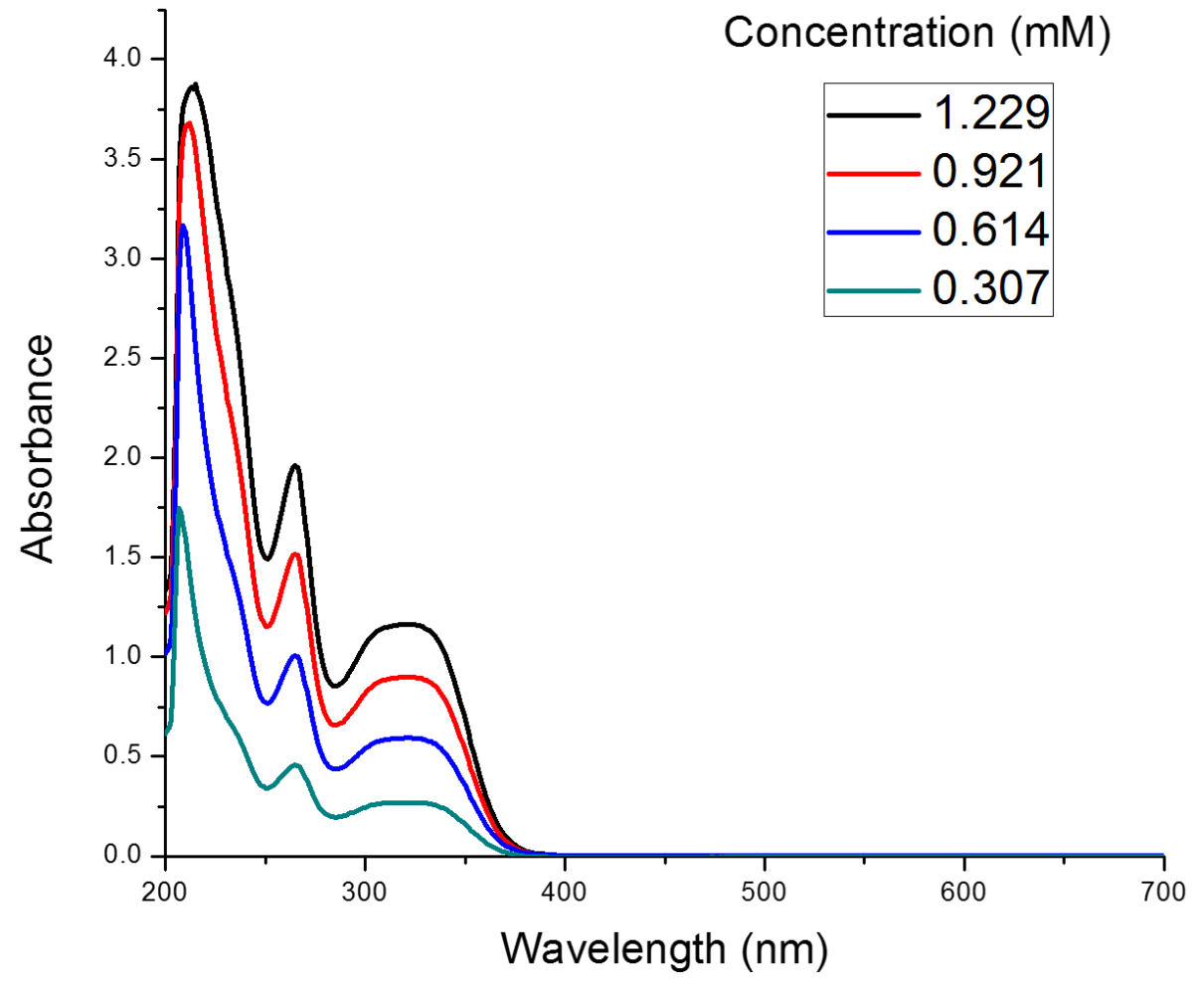

Figure S29. UV/Vis/NIR spectra of $4^{i P r}$ in THF at different concentrations at room temperature.

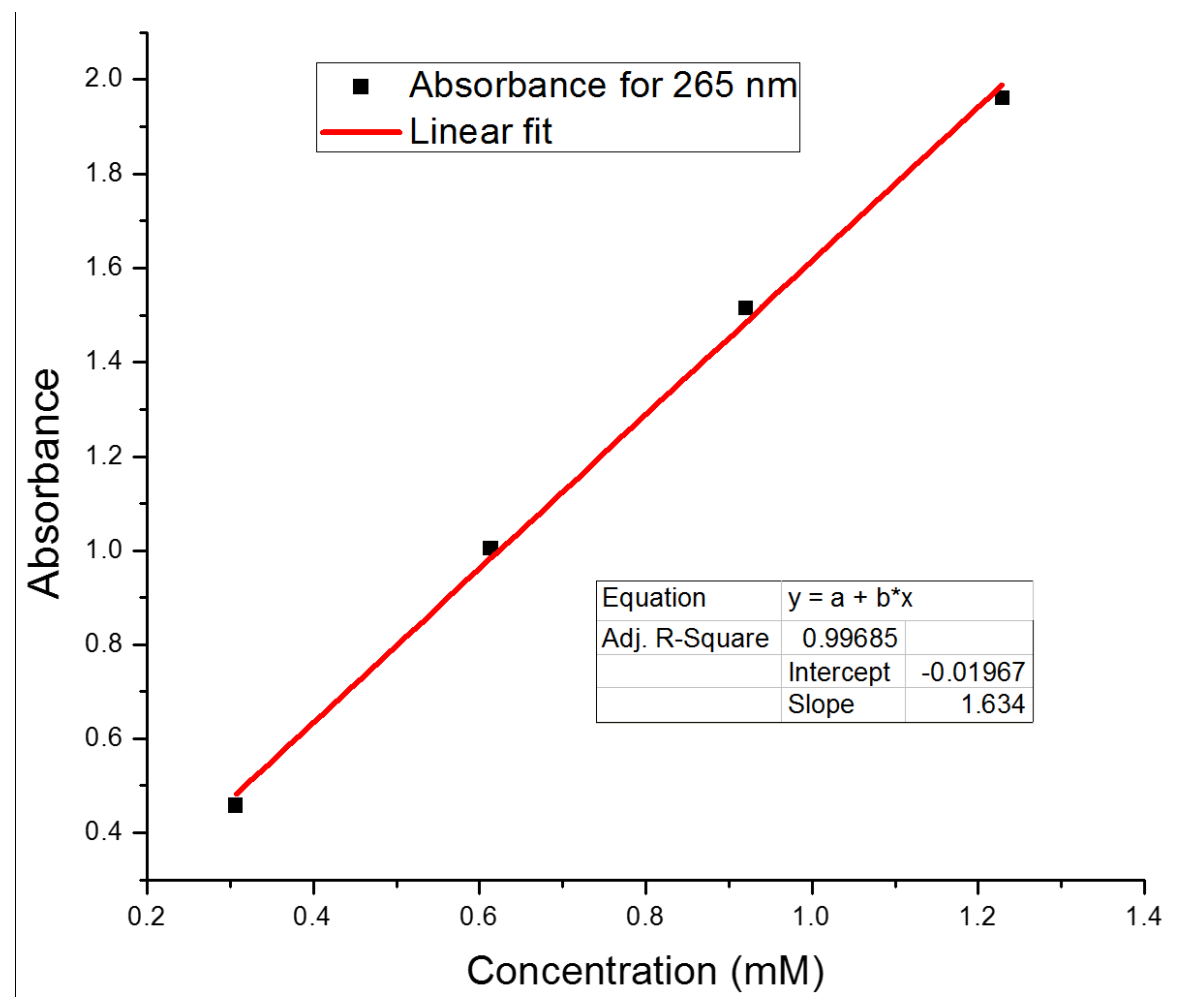

Figure S30. Linear regression of $4^{\mathrm{iPr}}$ at $265 \mathrm{~nm}$. 


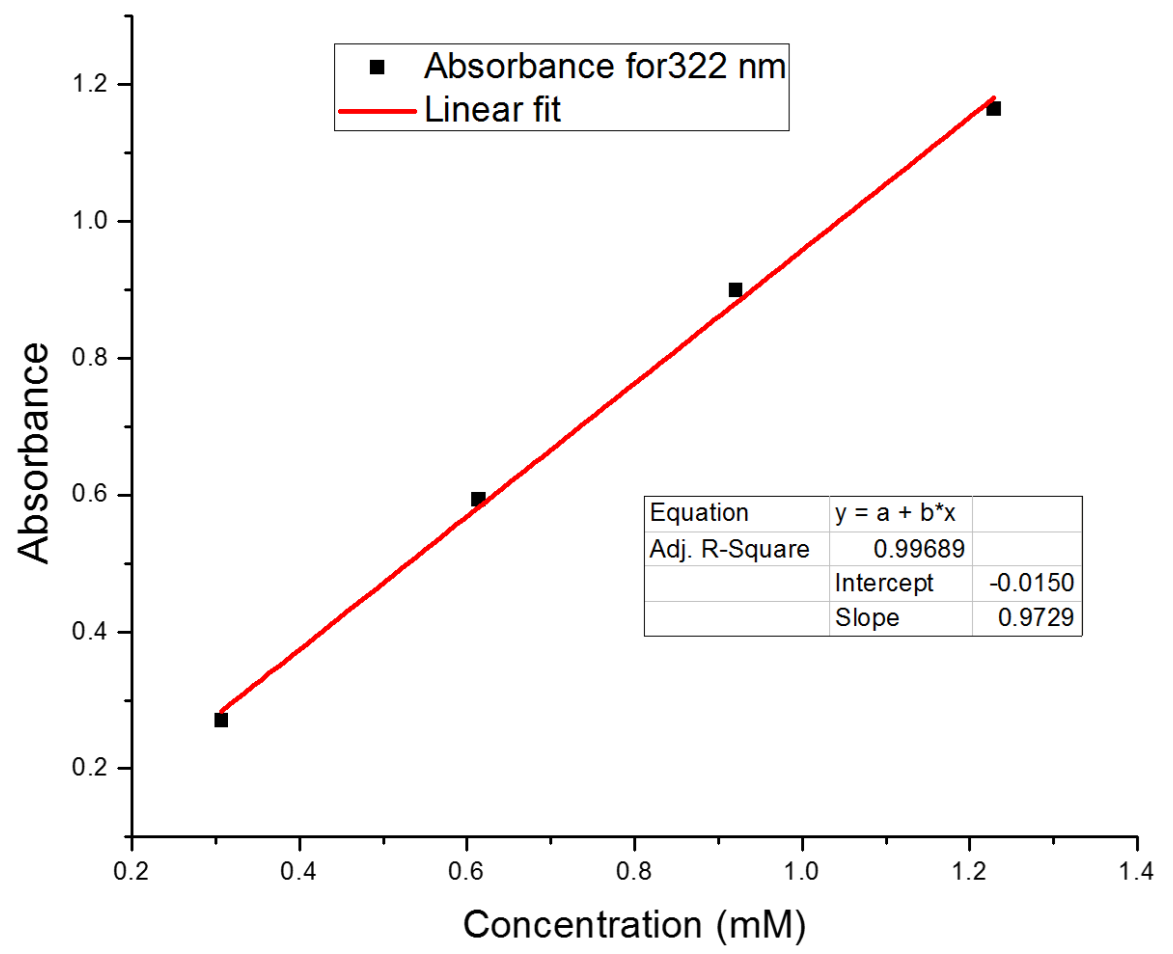

Figure S31. Linear regression of $4^{\mathrm{iPr}}$ at $322 \mathrm{~nm}$.

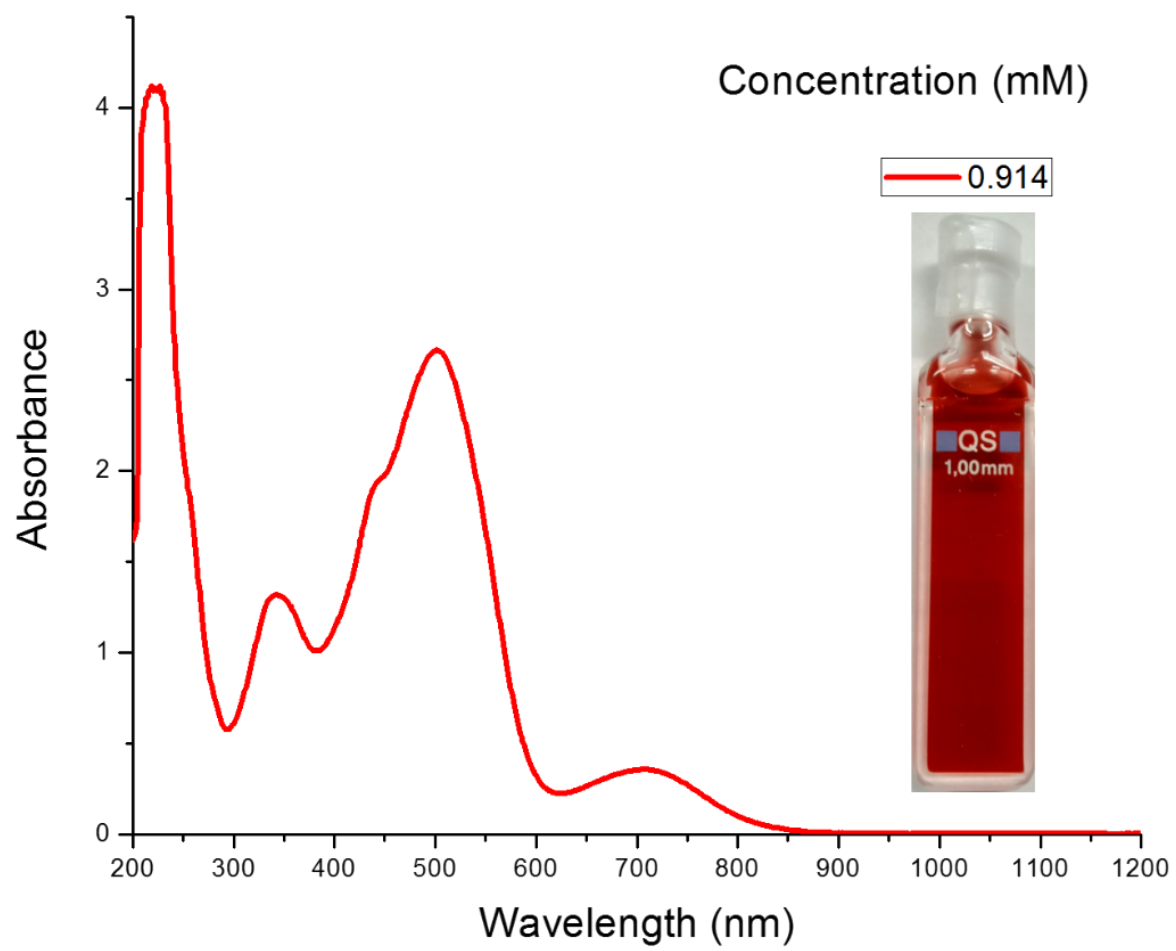

Figure S32. UV/Vis/NIR spectrum of $\mathbf{5}^{\text {iPr }}$ in THF at room temperature (the absorbance at $\lambda_{\max }=707 \mathrm{~nm}$ could be due to the formation of trace amount of $6^{\text {iPr }}$ during sample preparation by the contamination with adventitious source of oxygen). 
Molecular Structures of $2^{\text {Dip }}, 3^{\text {Dip }}, 4^{i \mathrm{Pr}}$, and $5^{i \mathrm{Pr}}$

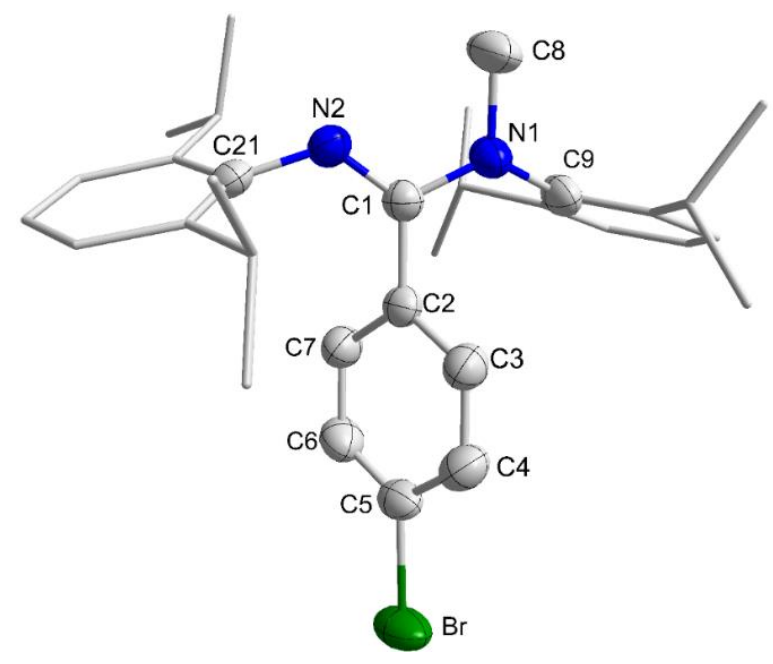

Figure S33. Molecular structure of $2^{\text {Dip }}$ with thermal ellipsoids at $50 \%$ probability level. All $\mathrm{H}$ atoms are omitted for clarity reasons. Selected bond lengths $[\AA]$ and bond angles [ $\left[^{\circ}\right]$ : N1-C1 1.382(2), N2-C1 1.283(2), C1-C2 1.493(3), C2C3 1.383(3), C3-C4 1.378(3), C4-C5 1.372(3), C5-C6 1.368(3), C6-C7 1.386(3), C7-C2 1.382(3), C5-Br 1.900(2); N1C1-C2 117.52(17).

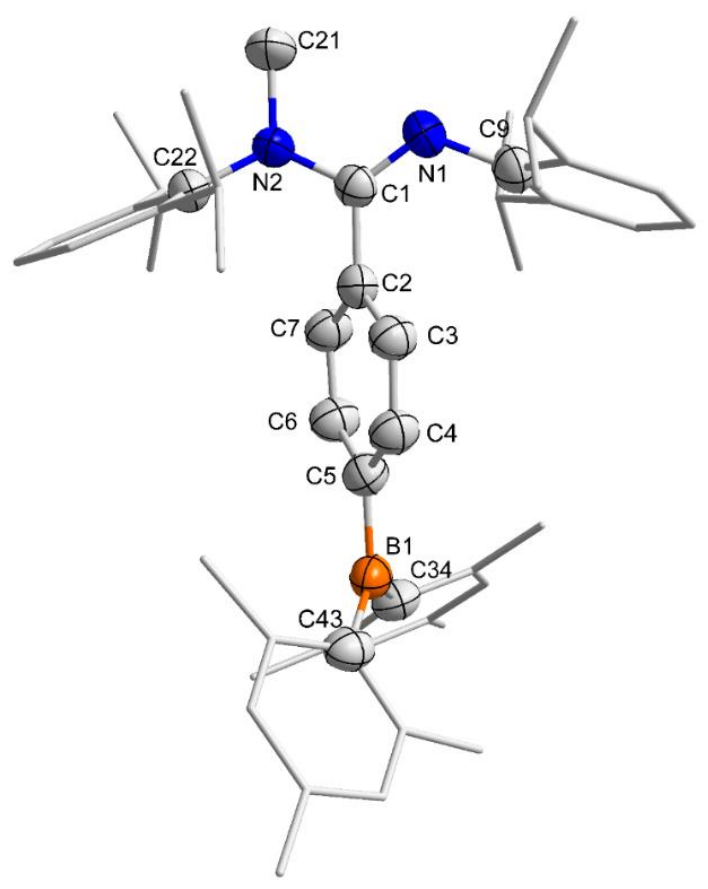

Figure S34. Molecular structure of $3^{\text {Dip }}$ with thermal ellipsoids at $50 \%$ probability level. All $\mathrm{H}$ atoms are omitted for clarity reasons. Selected bond lengths $[\AA ̊ 0]$ and bond angles $\left[^{\circ}\right]$ : N1-C1 1.281(2), N2-C1 1.371(2), C1-C2 1.493(2), C2C3 1.383(2), C3-C4 1.378(2), C4-C5 1.392(2), C5-C6 1.396(2), C6-C7 1.374(2), C7-C2 1.388(2), C5-B1 1.563(2); N1C1-N2 118.21(13), C43-B1-C34 124.52(15). 


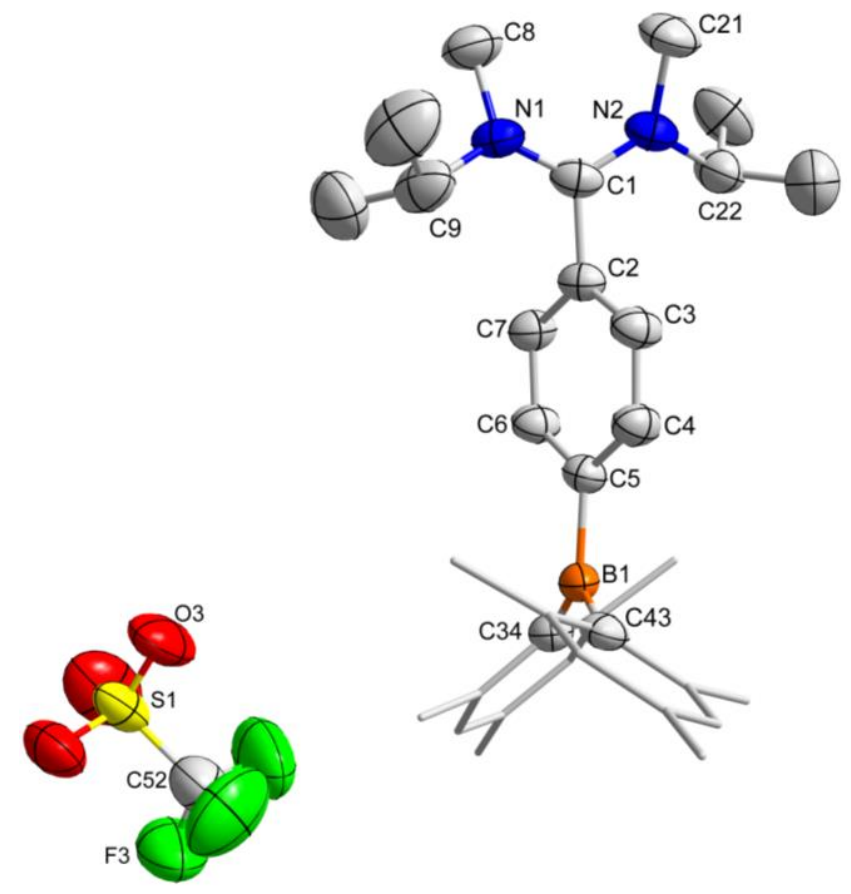

Figure S35. Molecular structure of $\mathbf{4}^{\text {iPr }}$ with thermal ellipsoids at 50\% probability level. All $\mathrm{H}$ atoms are omitted for clarity reasons. Selected bond lengths [Å] and bond angles [ $\left[^{\circ}\right]$ : N1-C1 1.311(4), N2-C1 1.332(4), C1-C2 1.501(4), C2C3 1.375(4), C3-C4 1.390(4), C4-C5 1.389(4), C5-C6 1.389(4), C6-C7 1.387(4), C7-C2 1.387(4), C5-B1 1.586(4); N1C1-C2 123.10(27), C43-B1-C34 124.96(26).

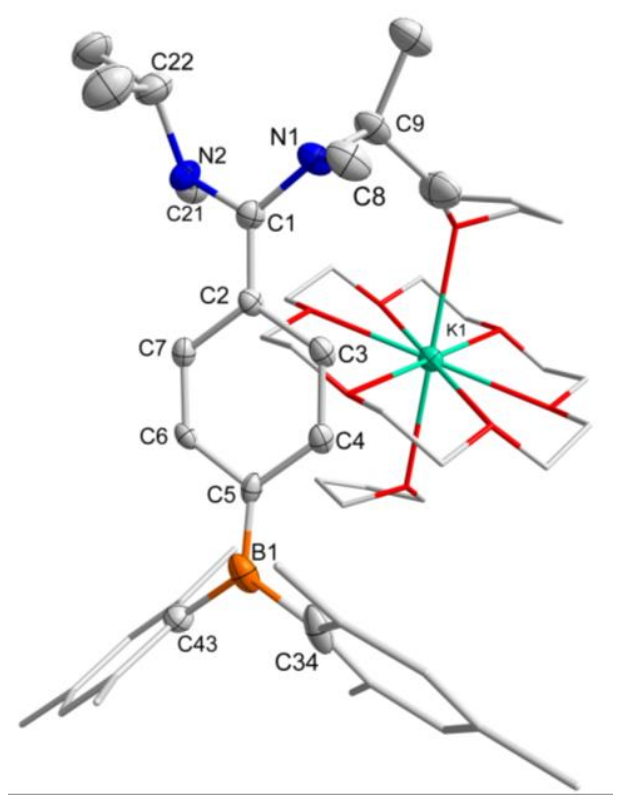

Figure S36. Molecular structure of $\mathbf{5}^{\mathbf{P r}}$ with thermal ellipsoids at 50\% probability level. All $\mathrm{H}$ atoms are omitted for clarity reasons. Due to the presence of structural disorder in this molecule we are not disussing the metrical parameters of it. 


\section{Crystallographic Details}

Single-crystal X-ray diffraction data of $\mathbf{5}^{\text {Dip }}, \mathbf{5}^{\text {iPr }}$, and $\mathbf{6}^{\text {Dip }}$ were collected at $100 \mathrm{~K}$ whereas $\mathbf{2}^{\text {Dip }}, \mathbf{3}^{\text {Dip }}, \mathbf{4}^{\text {Dip }}$, and $\mathbf{4}^{\text {iPr }}$ were collected at 293K, respectively using a XtaLAB AFC12 (RINC): Kappa single diffractometer with graphitemonochromated molybdenum $K \alpha$ radiation, $\lambda=0.71073 \AA$. Data were integrated using CrysAlisPro 1.171.39.29d (Rigaku Oxford Diffraction, 2017) software. ${ }^{S 4}$ Empirical absorption correction was done using spherical harmonics, implemented in SCALE3 ABSPACK scaling algorithm. The structure was solved with the SHELXT structure solution program $^{\mathrm{S5}}$ using Direct Methods and refined with the SHELXL refinement package ${ }^{\mathrm{S} 6}$ using Least Squares minimisation in the Olex-2 software. ${ }^{S 7}$ All the non-hydrogen atoms were refined with anisotropic thermal parameters. All the

hydrogen atoms were placed in geometrically calculated positions or found in the Fourier difference map and included in the refinement process using riding model. 
Table S1 Crystal data and structure refinement for $2^{\text {Dip }}$ (CCDC 2041458)

\begin{tabular}{|c|c|}
\hline Identification code & AJ1387 \\
\hline Empirical formula & $\mathrm{C}_{32} \mathrm{H}_{41} \mathrm{BrN}_{2}$ \\
\hline Formula weight & 533.58 \\
\hline Temperature/K & $293(2)$ \\
\hline Crystal system & triclinic \\
\hline Space group & P-1 \\
\hline $\mathrm{a} / \AA$ & $9.1354(2)$ \\
\hline$b / \AA$ & $10.3621(3)$ \\
\hline$c / \AA$ & $15.9295(5)$ \\
\hline$\alpha /^{\circ}$ & $90.751(2)$ \\
\hline$\beta /^{\circ}$ & $99.524(2)$ \\
\hline$\gamma /{ }^{\circ}$ & $97.310(2)$ \\
\hline Volume $/ \AA^{3}$ & $1474.15(7)$ \\
\hline Z & 2 \\
\hline$\rho_{\text {calc }} / \mathrm{cm}^{3}$ & 1.202 \\
\hline$\mu / \mathrm{mm}^{-1}$ & 1.415 \\
\hline$F(000)$ & 564.0 \\
\hline Crystal size $/ \mathrm{mm}^{3}$ & $0.24 \times 0.21 \times 0.19$ \\
\hline Radiation & $\operatorname{MoK} \alpha(\lambda=0.71073)$ \\
\hline $2 \Theta$ range for data collection $/^{\circ}$ & 5.19 to 57.814 \\
\hline Index ranges & $-10 \leq h \leq 12,-13 \leq k \leq 13,-21 \leq \mathrm{I} \leq 17$ \\
\hline Reflections collected & 29268 \\
\hline Independent reflections & $6854\left[R_{\text {int }}=0.0360, R_{\text {sigma }}=0.0409\right]$ \\
\hline Data/restraints/parameters & $6854 / 0 / 325$ \\
\hline Goodness-of-fit on $F^{2}$ & 1.017 \\
\hline Final $R$ indexes $[I>=2 \sigma(I)]$ & $R_{1}=0.0436, w R_{2}=0.0879$ \\
\hline Final $R$ indexes [all data] & $R_{1}=0.0777, w R_{2}=0.0963$ \\
\hline Largest diff. peak/hole / e $\AA^{-3}$ & $0.27 /-0.33$ \\
\hline
\end{tabular}




\section{Table S2 Crystal data and structure refinement for $3^{\text {Dip }}$ (CCDC 2041459)}

\begin{tabular}{|c|c|}
\hline Identification code & AJ1599 \\
\hline Empirical formula & $\mathrm{C}_{50} \mathrm{H}_{63} \mathrm{BN}_{2}$ \\
\hline Formula weight & 702.83 \\
\hline Temperature/K & $293(2)$ \\
\hline Crystal system & orthorhombic \\
\hline Space group & Pbca \\
\hline $\mathrm{a} / \AA$ & $15.7394(5)$ \\
\hline $\mathrm{b} / \AA ̊ \AA$ & $23.6105(8)$ \\
\hline$c / \AA$ & $23.9959(7)$ \\
\hline$\alpha /^{\circ}$ & 90 \\
\hline$\beta /^{\circ}$ & 90 \\
\hline$\gamma /{ }^{\circ}$ & 90 \\
\hline Volume $/ \AA^{3}$ & $8917.2(5)$ \\
\hline Z & 8 \\
\hline$\rho_{\text {calc }} / \mathrm{cm}^{3}$ & 1.047 \\
\hline$\mu / \mathrm{mm}^{-1}$ & 0.059 \\
\hline$F(000)$ & 3056.0 \\
\hline Crystal size $/ \mathrm{mm}^{3}$ & $0.34 \times 0.29 \times 0.21$ \\
\hline Radiation & $\operatorname{MoK} \alpha(\lambda=0.71073)$ \\
\hline $2 \Theta$ range for data collection $/^{\circ}$ & 5.456 to 57.942 \\
\hline Index ranges & $-21 \leq h \leq 17,-32 \leq k \leq 30,-31 \leq \mathrm{I} \leq 31$ \\
\hline Reflections collected & 76005 \\
\hline Independent reflections & $10807\left[R_{\text {int }}=0.1322, R_{\text {sigma }}=0.0648\right]$ \\
\hline Data/restraints/parameters & $10807 / 0 / 493$ \\
\hline Goodness-of-fit on $F^{2}$ & 1.026 \\
\hline Final $R$ indexes $[I>=2 \sigma(I)]$ & $\mathrm{R}_{1}=0.0660, \mathrm{wR}_{2}=0.1707$ \\
\hline Final $R$ indexes [all data] & $\mathrm{R}_{1}=0.1083, w \mathrm{R}_{2}=0.1962$ \\
\hline Largest diff. peak/hole / e $\AA^{-3}$ & $0.20 /-0.19$ \\
\hline
\end{tabular}




\section{Table S3 Crystal data and structure refinement for $4^{\text {Dip }}$ (CCDC 2041460)}

\begin{tabular}{|c|c|}
\hline Identification code & AJ1229 \\
\hline Empirical formula & $\mathrm{C}_{54} \mathrm{H}_{69} \mathrm{BF}_{3} \mathrm{~N}_{3} \mathrm{O}_{3} \mathrm{~S}$ \\
\hline Formula weight & 907.99 \\
\hline Temperature/K & 239.99(10) \\
\hline Crystal system & monoclinic \\
\hline Space group & $\mathrm{P} 21 / \mathrm{n}$ \\
\hline $\mathrm{a} / \AA$ & $14.9223(9)$ \\
\hline $\mathrm{b} / \AA$ & $15.8434(9)$ \\
\hline$c / \AA$ & $22.1840(14)$ \\
\hline$\alpha /^{\circ}$ & 90 \\
\hline$\beta /^{\circ}$ & $97.197(6)$ \\
\hline$\gamma /{ }^{\circ}$ & 90 \\
\hline Volume $/ \AA^{3}$ & $5203.4(5)$ \\
\hline Z & 4 \\
\hline$\rho_{\text {calc }} / \mathrm{cm}^{3}$ & 1.159 \\
\hline$\mu / \mathrm{mm}^{-1}$ & 0.116 \\
\hline$F(000)$ & 1944.0 \\
\hline Crystal size $/ \mathrm{mm}^{3}$ & $0.21 \times 0.19 \times 0.12$ \\
\hline Radiation & $\operatorname{MoK} \alpha(\lambda=0.71073)$ \\
\hline $2 \Theta$ range for data collection $/^{\circ}$ & 5.034 to 58.228 \\
\hline Index ranges & $-20 \leq h \leq 17,-18 \leq k \leq 21,-27 \leq \mathrm{I} \leq 29$ \\
\hline Reflections collected & 49040 \\
\hline Independent reflections & $11998\left[R_{\text {int }}=0.0378, R_{\text {sigma }}=0.0368\right]$ \\
\hline Data/restraints/parameters & $11998 / 0 / 603$ \\
\hline Goodness-of-fit on $F^{2}$ & 1.059 \\
\hline Final $R$ indexes $[I>=2 \sigma(I)]$ & $R_{1}=0.0623, w R_{2}=0.1782$ \\
\hline Final $R$ indexes [all data] & $\mathrm{R}_{1}=0.0880, w \mathrm{R}_{2}=0.1928$ \\
\hline Largest diff. peak/hole / e $\AA^{-3}$ & $0.51 /-0.44$ \\
\hline
\end{tabular}




\section{Table S4 Crystal data and structure refinement for $5^{\text {Dip }}$ (CCDC 2041461)}

\begin{tabular}{|c|c|}
\hline Identification code & AJ1395 \\
\hline Empirical formula & $\mathrm{C}_{51} \mathrm{H}_{66} \mathrm{BN}_{2}$ \\
\hline Formula weight & 717.86 \\
\hline Temperature/K & $100.01(10)$ \\
\hline Crystal system & monoclinic \\
\hline Space group & $\mathrm{P} 2{ }_{1} / \mathrm{c}$ \\
\hline $\mathrm{a} / \AA$ & $15.9878(5)$ \\
\hline $\mathrm{b} / \AA$ & $17.5315(10)$ \\
\hline$c / \AA$ & $18.1549(7)$ \\
\hline$\alpha /^{\circ}$ & 90 \\
\hline$\beta /^{\circ}$ & $101.432(4)$ \\
\hline$\gamma /{ }^{\circ}$ & 90 \\
\hline Volume $/ \AA^{3}$ & $4987.7(4)$ \\
\hline Z & 4 \\
\hline$\rho_{\text {calcg }} / \mathrm{cm}^{3}$ & 0.956 \\
\hline$\mu / \mathrm{mm}^{-1}$ & 0.054 \\
\hline$F(000)$ & 1564.0 \\
\hline Crystal size $/ \mathrm{mm}^{3}$ & $0.29 \times 0.24 \times 0.18$ \\
\hline Radiation & $\operatorname{MoK} \alpha(\lambda=0.71073)$ \\
\hline $2 \Theta$ range for data collection $/^{\circ}$ & 5.134 to 58.068 \\
\hline Index ranges & $-19 \leq h \leq 21,-23 \leq k \leq 16,-23 \leq \mathrm{I} \leq 23$ \\
\hline Reflections collected & 73679 \\
\hline Independent reflections & $12014\left[R_{\text {int }}=0.1035, R_{\text {sigma }}=0.0849\right]$ \\
\hline Data/restraints/parameters & $12014 / 24 / 533$ \\
\hline Goodness-of-fit on $F^{2}$ & 1.032 \\
\hline Final $R$ indexes $[I>=2 \sigma(I)]$ & $\mathrm{R}_{1}=0.0907, \mathrm{wR}_{2}=0.2233$ \\
\hline Final $R$ indexes [all data] & $\mathrm{R}_{1}=0.1373, w \mathrm{R}_{2}=0.2472$ \\
\hline Largest diff. peak/hole / e $\AA^{-3}$ & $0.34 /-0.28$ \\
\hline
\end{tabular}


Table S5 Crystal data and structure refinement for $6^{\text {Dip }}$ (CCDC 2041462)

\begin{tabular}{|c|c|}
\hline Identification code & aj1391 \\
\hline Empirical formula & $\mathrm{C}_{71} \mathrm{H}_{106} \mathrm{BKN}_{2} \mathrm{O}_{8}$ \\
\hline Formula weight & 1165.48 \\
\hline Temperature/K & $108.66(10)$ \\
\hline Crystal system & monoclinic \\
\hline Space group & $\mathrm{P} 2{ }_{1} / \mathrm{c}$ \\
\hline $\mathrm{a} / \AA ̊$ & $15.4973(4)$ \\
\hline $\mathrm{b} / \AA ̊ \AA$ & $16.6318(4)$ \\
\hline$c / \AA$ & $28.1403(7)$ \\
\hline$\alpha /^{\circ}$ & 90 \\
\hline$\beta /^{\circ}$ & $92.897(2)$ \\
\hline$\gamma /{ }^{\circ}$ & 90 \\
\hline Volume $/ \AA^{3}$ & $7243.8(3)$ \\
\hline Z & 4 \\
\hline$\rho_{\text {calc }} / \mathrm{cm}^{3}$ & 1.069 \\
\hline$\mu / \mathrm{mm}^{-1}$ & 0.124 \\
\hline$F(000)$ & 2536.0 \\
\hline Crystal size $/ \mathrm{mm}^{3}$ & $0.31 \times 0.24 \times 0.24$ \\
\hline Radiation & $\operatorname{MoK} \alpha(\lambda=0.71073)$ \\
\hline $2 \Theta$ range for data collection $/^{\circ}$ & 4.534 to 58.104 \\
\hline Index ranges & $-20 \leq h \leq 20,-20 \leq k \leq 22,-36 \leq 1 \leq 35$ \\
\hline Reflections collected & 93280 \\
\hline Independent reflections & $17181\left[R_{\text {int }}=0.0584, R_{\text {sigma }}=0.0543\right]$ \\
\hline Data/restraints/parameters & $17181 / 0 / 758$ \\
\hline Goodness-of-fit on $F^{2}$ & 1.038 \\
\hline Final $R$ indexes $[I>=2 \sigma(I)]$ & $R_{1}=0.0575, w R_{2}=0.1348$ \\
\hline Final $R$ indexes [all data] & $\mathrm{R}_{1}=0.0833, \mathrm{wR}_{2}=0.1455$ \\
\hline Largest diff. peak/hole / e $\AA^{-3}$ & $0.89 /-0.42$ \\
\hline
\end{tabular}




\begin{tabular}{|c|c|}
\hline Identification code & AJ1111 \\
\hline Empirical formula & $\mathrm{C}_{34} \mathrm{H}_{46} \mathrm{BF}_{3} \mathrm{~N}_{2} \mathrm{O}_{3} \mathrm{~S}$ \\
\hline Formula weight & 630.60 \\
\hline Temperature/K & $293(2)$ \\
\hline Crystal system & orthorhombic \\
\hline Space group & $\mathrm{P} 2{ }_{1} 2_{1} 2_{1}$ \\
\hline$a / \AA$ & $8.3933(5)$ \\
\hline $\mathrm{b} / \AA$ & $15.4652(11)$ \\
\hline$c / \AA$ & $27.3449(17)$ \\
\hline$\alpha /^{\circ}$ & 90 \\
\hline$\beta /^{\circ}$ & 90 \\
\hline$\gamma /{ }^{\circ}$ & 90 \\
\hline Volume $/ \AA^{3}$ & $3549.5(4)$ \\
\hline Z & 4 \\
\hline$\rho_{\text {calc }} / \mathrm{cm}^{3}$ & 1.180 \\
\hline$\mu / \mathrm{mm}^{-1}$ & 0.141 \\
\hline$F(000)$ & 1344.0 \\
\hline Crystal size $/ \mathrm{mm}^{3}$ & $0.32 \times 0.26 \times 0.22$ \\
\hline Radiation & $\operatorname{MoK} \alpha(\lambda=0.71073)$ \\
\hline $2 \Theta$ range for data collection $/^{\circ}$ & 5.076 to 57.904 \\
\hline Index ranges & $-10 \leq h \leq 11,-16 \leq k \leq 20,-37 \leq l \leq 35$ \\
\hline Reflections collected & 33197 \\
\hline Independent reflections & $8240\left[R_{\text {int }}=0.0899, R_{\text {sigma }}=0.0798\right]$ \\
\hline Data/restraints/parameters & $8240 / 0 / 409$ \\
\hline Goodness-of-fit on $F^{2}$ & 1.020 \\
\hline Final $R$ indexes $[I>=2 \sigma(I)]$ & $R_{1}=0.0592, w R_{2}=0.1420$ \\
\hline Final $R$ indexes [all data] & $R_{1}=0.1084, w R_{2}=0.1604$ \\
\hline Largest diff. peak/hole / e $\AA^{-3}$ & $0.22 /-0.19$ \\
\hline
\end{tabular}


Table S7 Crystal data and structure refinement for $5^{\text {iPr }}$ (CCDC 2041464)

\begin{tabular}{|c|c|}
\hline Identification code & aj1402 \\
\hline Empirical formula & $\mathrm{C}_{53} \mathrm{H}_{86} \mathrm{BKN}_{2} \mathrm{O}_{8}$ \\
\hline Formula weight & 929.14 \\
\hline Temperature/K & $100(2)$ \\
\hline Crystal system & triclinic \\
\hline Space group & $\mathrm{P}-1$ \\
\hline $\mathrm{a} / \AA ̊ \AA$ & $11.9400(3)$ \\
\hline $\mathrm{b} / \AA ̊ \AA$ & $16.1972(4)$ \\
\hline$c / \AA ̊$ & $16.2337(5)$ \\
\hline$\alpha /^{\circ}$ & $70.887(3)$ \\
\hline$\beta /{ }^{\circ}$ & $77.191(2)$ \\
\hline$\gamma /{ }^{\circ}$ & $68.408(2)$ \\
\hline Volume/ $\AA^{3}$ & 2739.92(14) \\
\hline Z & 2 \\
\hline$\rho_{\text {calcg }} / \mathrm{cm}^{3}$ & 1.126 \\
\hline$\mu / \mathrm{mm}^{-1}$ & 0.147 \\
\hline$F(000)$ & 1012.0 \\
\hline Crystal size $/ \mathrm{mm}^{3}$ & $0.340 \times 0.320 \times 0.170$ \\
\hline Radiation & $\operatorname{MoK} \alpha(\lambda=0.71073)$ \\
\hline $2 \Theta$ range for data collection $/^{\circ}$ & 5.348 to 57.986 \\
\hline Index ranges & $-16 \leq h \leq 15,-21 \leq k \leq 21,-20 \leq \mathrm{I} \leq 21$ \\
\hline Reflections collected & 44117 \\
\hline Independent reflections & $12575\left[R_{\text {int }}=0.0339, R_{\text {sigma }}=0.0360\right]$ \\
\hline Data/restraints/parameters & $12575 / 900 / 926$ \\
\hline Goodness-of-fit on $F^{2}$ & 1.068 \\
\hline Final $R$ indexes $[\mid>=2 \sigma(I)]$ & $R_{1}=0.0639, w R_{2}=0.1781$ \\
\hline Final $R$ indexes [all data] & $R_{1}=0.0814, w R_{2}=0.1897$ \\
\hline Largest diff. peak/hole / e $\AA^{-3}$ & $0.99 /-0.46$ \\
\hline
\end{tabular}




\section{EPR Spectroscopy}

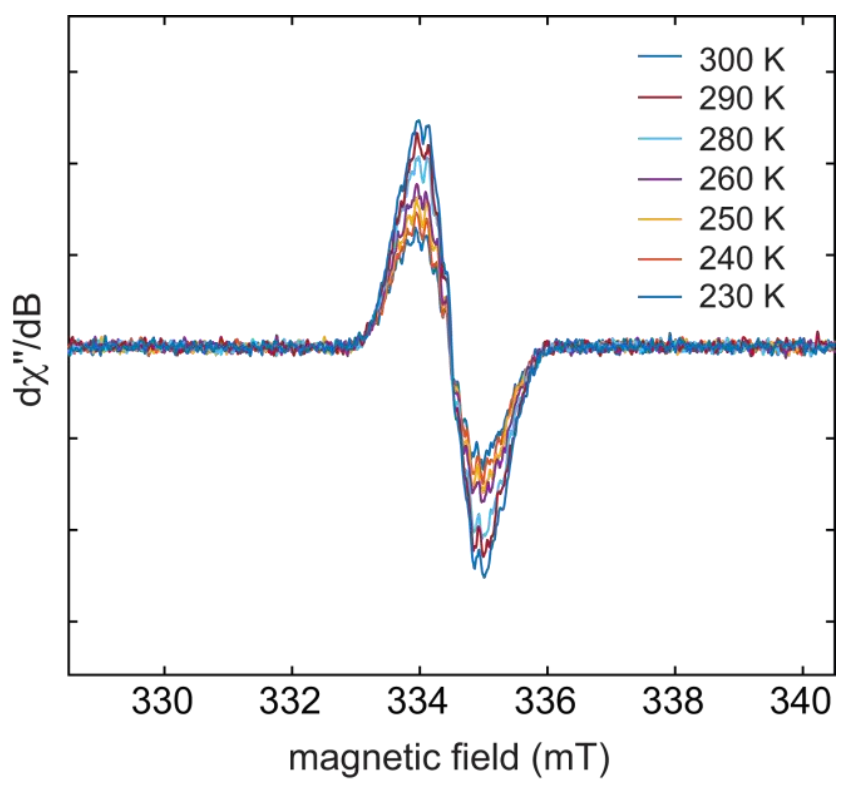

Figure S37. Variable temperature X-band EPR spectra of $5^{\text {Dip }}$ in tetrahydrofuran between 230 and $300 \mathrm{~K}$.
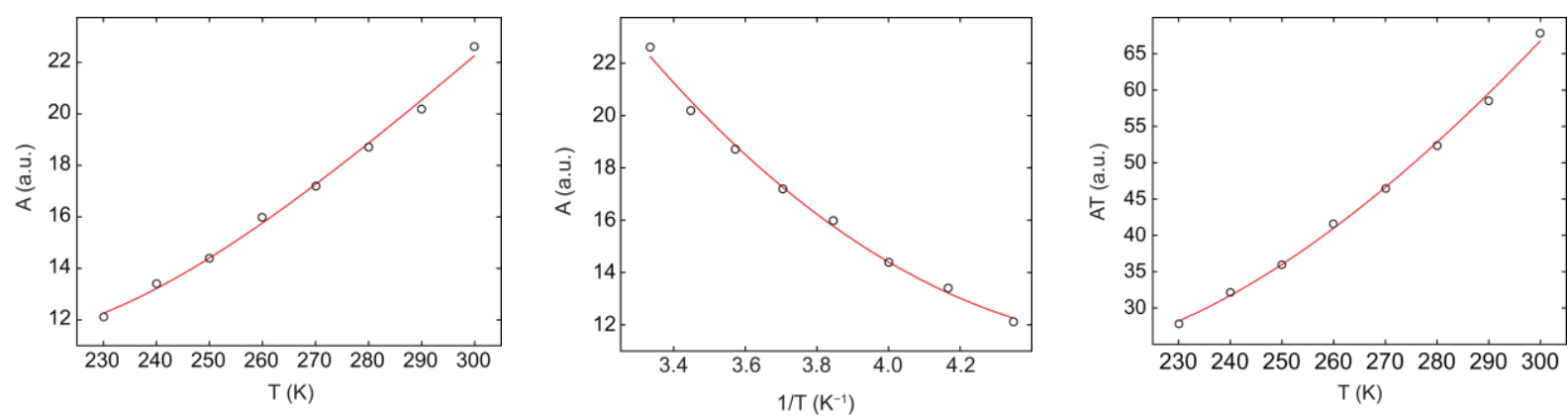

Figure S38. Three different representations of the temperature dependence of the double integral EPR intensity $(A)$ of $5^{\text {Dip }}$ in tetrahydrofuran solution. Circles $(\bigcirc)$ represent the experimental results and the red line corresponds to the fit with the Bleaney-Bowers equation. Fitting of the temperature-dependent double-integral intensity to the Bleaney-Bowers model gives a singlet-triplet gap of $2 \mathrm{~J}=-232 \mathrm{~cm}^{-1}\left(\Delta E_{\mathrm{ST}}=-0.66 \mathrm{kcal} \mathrm{mol}^{-1}\right)$, indicating a thermally excited triplet state. The characteristic half-field transition (and zero-field splittings) indicative of a triplet state could not be observed both in solution and in the solid state (powder sample). 


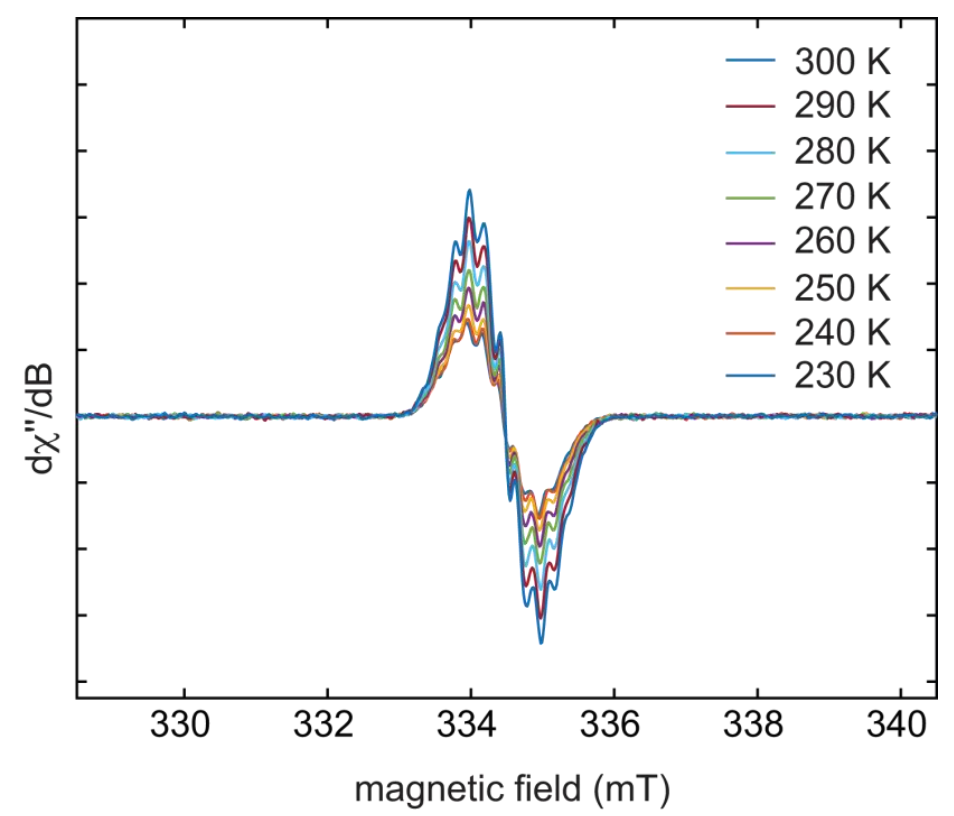

Figure S39. Variable temperature X-band EPR spectra of $5^{\text {iPr }}$ in tetrahydrofuran between 230 and $300 \mathrm{~K}$. The isotropic EPR signals are centered around $g=2.0028$.
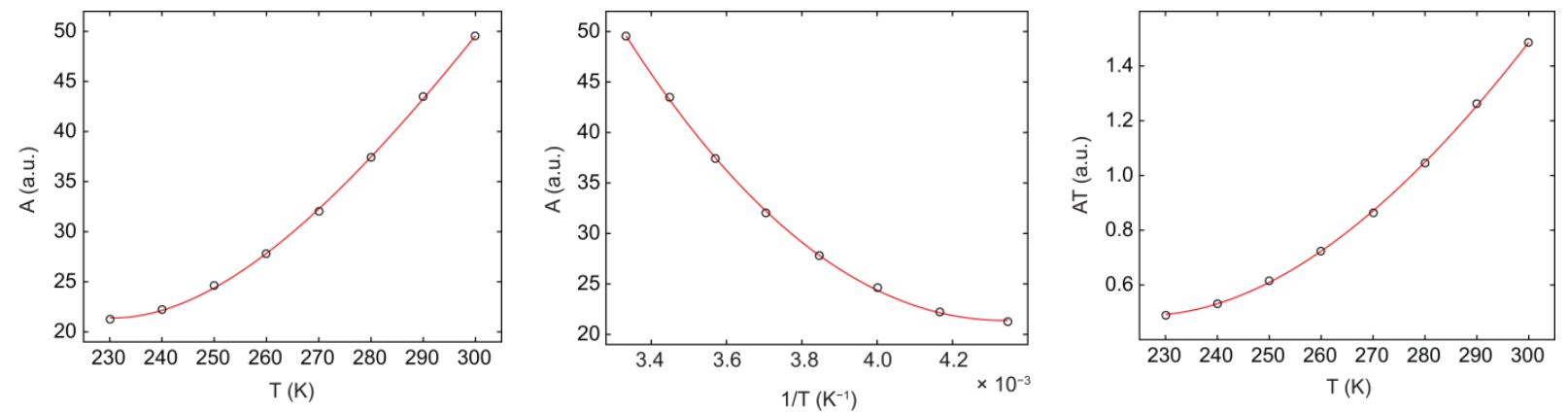

Figure S40. Three different representations of the temperature dependence of the double integral EPR intensity $(A)$ of $5^{i P r}$ in tetrahydrofuran solution. Circles $(\bigcirc)$ represent the experimental results and the red line corresponds to the fit with the Bleaney-Bowers equation. Fitting of the temperature-dependent double-integral intensity to the Bleaney-Bowers model gives a singlet-triplet gap of $2 \mathrm{~J}=-257 \mathrm{~cm}^{-1}\left(\Delta E_{\mathrm{ST}}=-0.73 \mathrm{~kJ} \mathrm{~mol}^{-1}\right)$, indicating a thermally excited triplet state. 


\section{Cyclic Voltammetry and Spectroelectrochemistry}

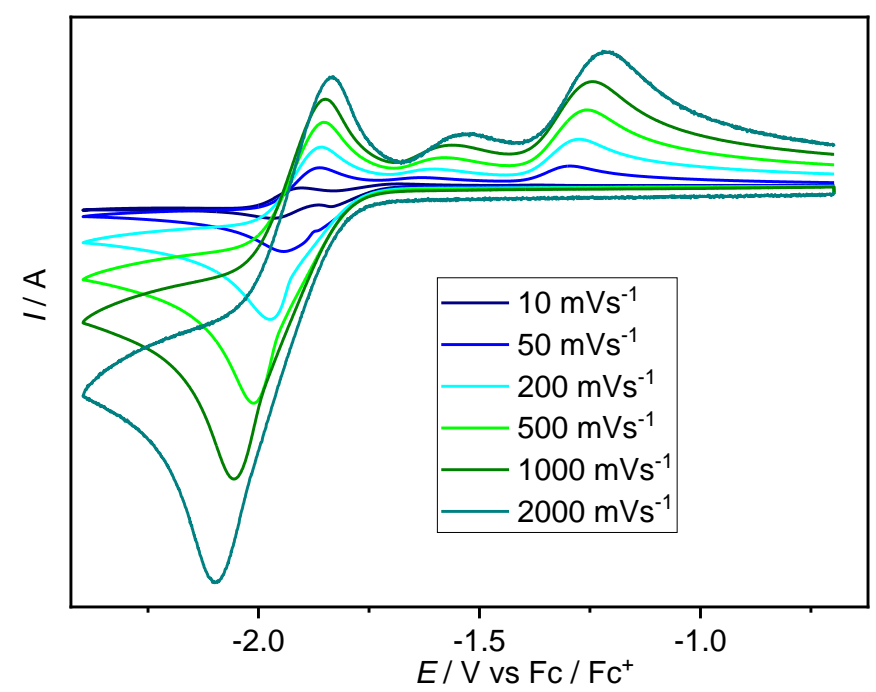

Figure S41. Cyclic voltammogram of of $4^{\text {Dip }}$ measured at different scan rate in THF $\left(0.1 \mathrm{M}\left[n \mathrm{Bu}_{4} \mathrm{~N}\right]\left[\mathrm{PF}_{6}\right]\right)$.

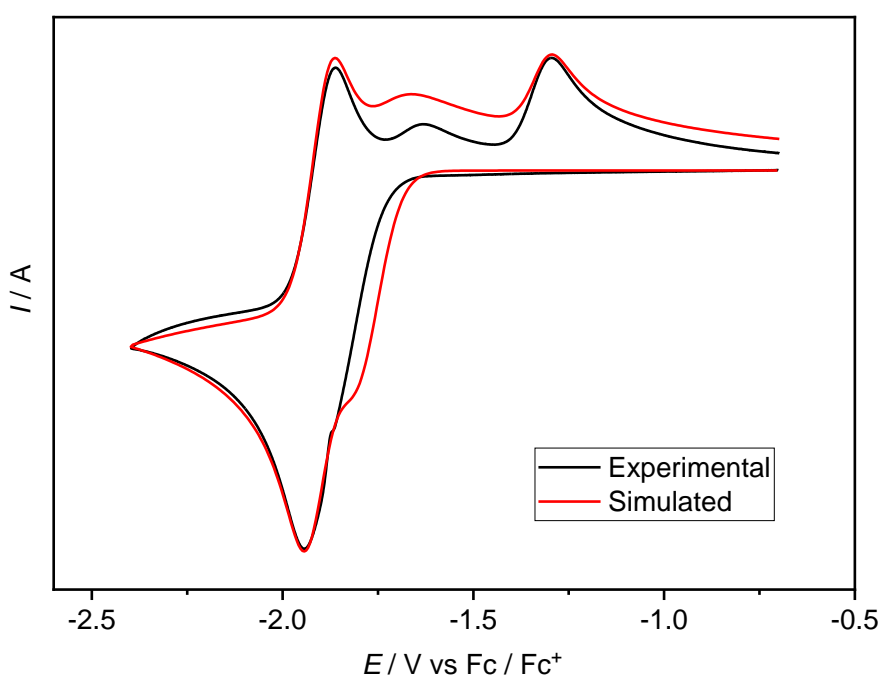

Figure S42. Obtained (black) and simulated (red, using DigiElch) cyclic voltammogram of compound $4^{\text {Dip }}$ in THF (0.1 $\left.\mathrm{M}\left[n \mathrm{Bu}_{4} \mathrm{~N}\right]\left[\mathrm{PF}_{6}\right]\right)$ at scan rate of $50 \mathrm{mVs}^{-1}$. Digital simulation indicated an electrochemical-conformational change/chemical process-electrochemical (ECE) mechanism (Scheme 1).

Based on the solid-state moleccular structure $4^{\mathrm{Dip}}$ is in the amphi-conformation, whereas $6^{\mathrm{Dip}}$ (one-electron reduced species) and $5^{\text {Dip }}$ (one-electron reduced species) are in an anti-confirmation (Figure 1). ${ }^{58}$ Based on this we are assuming first one-electron reduction of amphi-4 ${ }^{\text {Dip }}$ is converted to the amphi-conformation of $6^{\text {Dip }}$. Then amphi- $6^{\text {Dip }}$ rearranged anti- $6^{\text {Dip }}$ (conformational change) before it reduced to anti-5 ${ }^{\text {Dip }}$ (Scheme S1). 


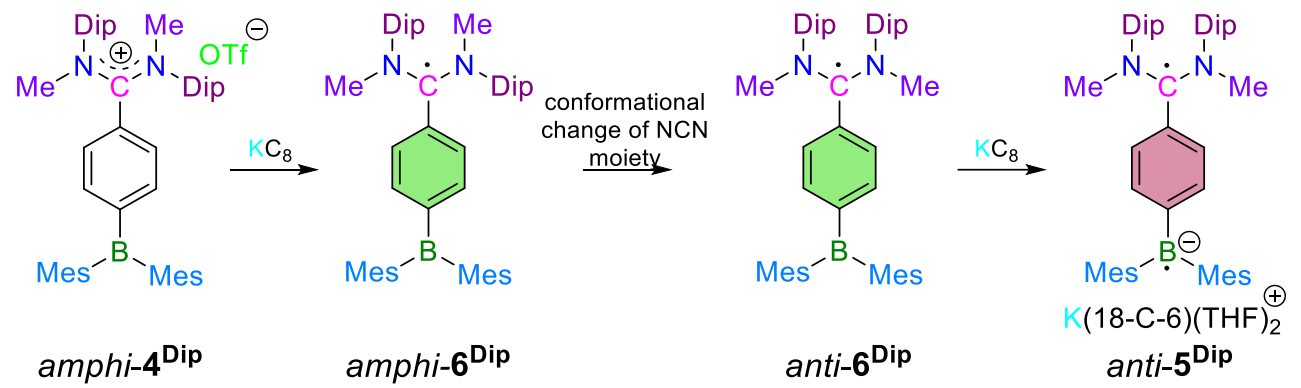

Scheme S1. Possible mechanism (electrochemical-conformational change/chemical process-electrochemical) for the electrochemical reduction of $4^{\text {Dip }}$.

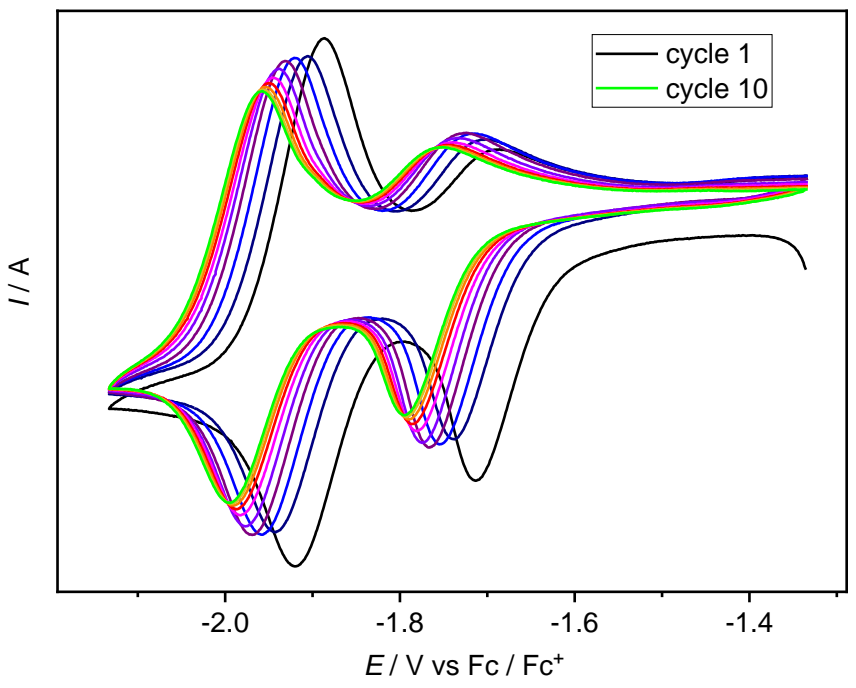

Figure S43. Thin layer cyclic voltammetry of $4^{\text {Dip }}\left(10\right.$ cycles) in THF $\left(0.1 \mathrm{M}\left[n B u_{4} N\right]\left[P_{6}\right]\right)$ at scan rate of $2 \mathrm{mVs}^{-1}$.
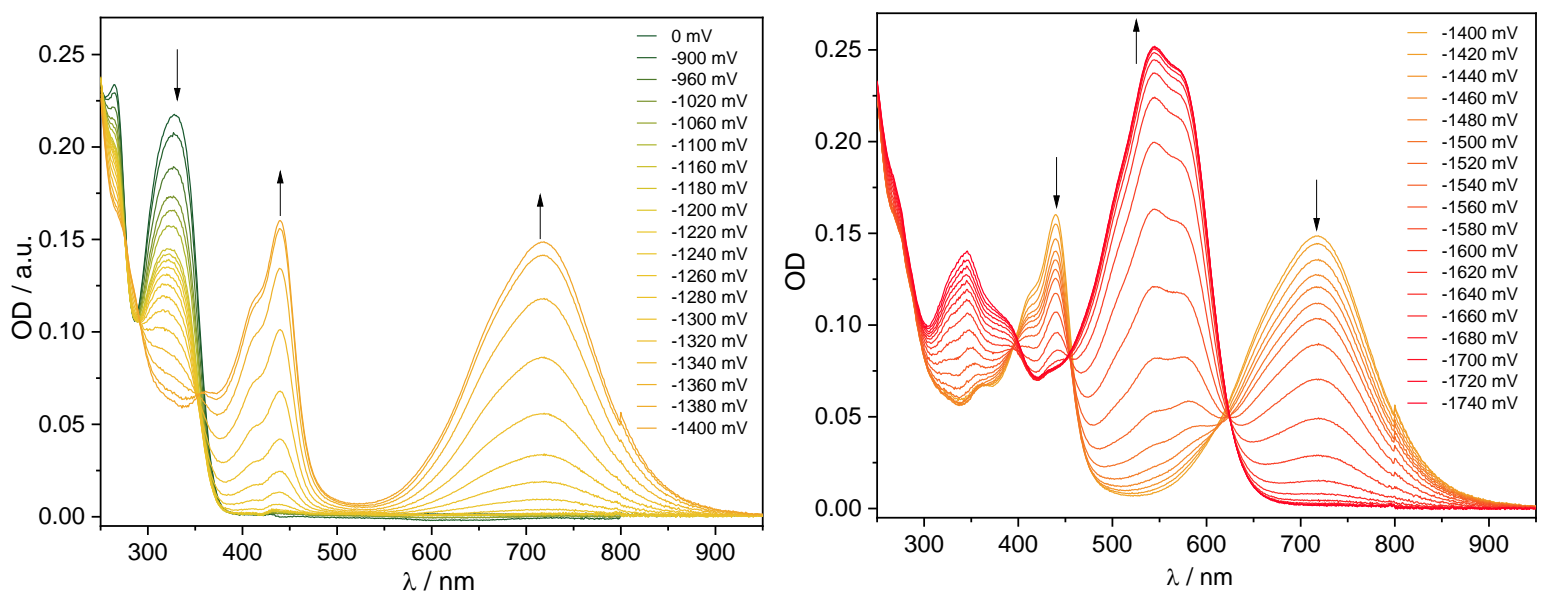

Figure S44. UV/Vis/NIR spectroelectrochemistry of $4^{\text {Dip }}$ in THF (0.1 M $\left.\left[n \mathrm{Bu}_{4} \mathrm{~N}\right][\mathrm{PF} 6]\right)$. 


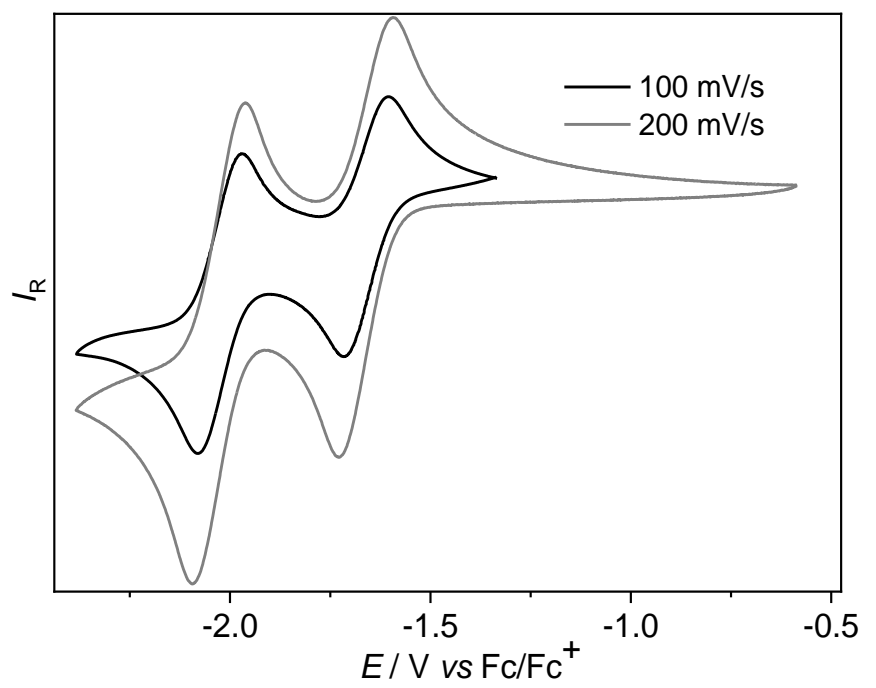

Figure S45. Cyclic voltammogram of $4^{i \mathrm{Pr}}$ in THF $\left(0.1 \mathrm{M}\left[n \mathrm{Bu}_{4} \mathrm{~N}\right]\left[\mathrm{PF}_{6}\right]\right)$ measured at different scan rates. 


\section{Quantum Chemical Calculations}

All the DFT calculations were performed using Gaussian 16 suite. ${ }^{59}$ The gas-phase geometry optimizations were done with the respective functional (M062X, B3LYP, wB97XD, MN12SX, B3LYP, or MN12L) and the 6-31G(d,p) or Def2SVP basis sets. Frequency analysis was performed to verify the stationary state geometry. In all cases no imaginary frequency was found. For $5^{\mathrm{DIP}} / 5^{\mathrm{iPr}}$ the singlet state geometries were optimized using restricted-DFT and unrestricted broken-symmetry DFT wavefunctions.

The potential energy scan (at UB3LYP/6-31g $(d, p)$ level) for compound 5 was performed to see influence of dihedral angles of N-C-N and C-B-C planes with central benzene ring on energies of singlet and triplet state as well as the energy difference between these two states. The bulky substituents were replaced by methyl group to reduce the computational cost.

TD-DFT calculations were performed at M062X/Def2SVP level on (U)M062X/Def2SVP optimized geometry for $4^{\text {DIP }}$, $5^{\text {DIP }}$ and $6^{\text {DIP. }}$. 


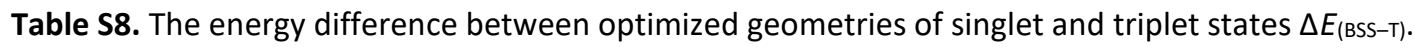

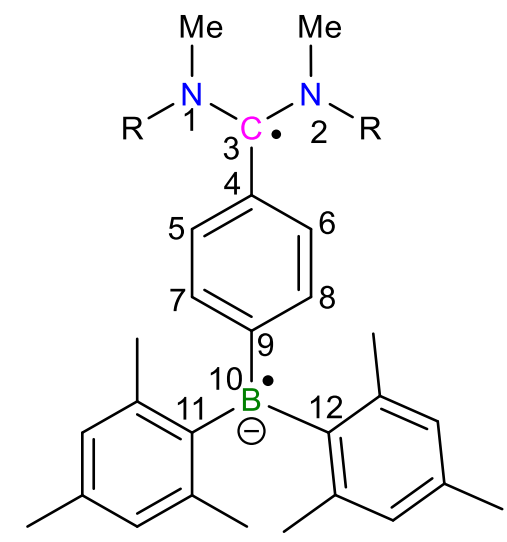

\begin{tabular}{|c|c|c|c|c|c|c|}
\hline & \multirow[t]{2}{*}{ DFT-level } & \multicolumn{2}{|c|}{ Dihedral angle (BSS) $/^{\circ}$} & \multicolumn{2}{|c|}{ Dihedral angle $(\mathrm{T}) /^{\circ}$} & \multirow{2}{*}{$\begin{array}{l}\Delta E_{(\mathrm{BSS}-\mathrm{T})} / \\
\mathrm{kcal} \mathrm{mol}^{-1}\end{array}$} \\
\hline & & $\begin{array}{l}\mathrm{N} 1-\mathrm{C} 3-\mathrm{C} 4-\mathrm{C} 5 / \\
\mathrm{N} 2-\mathrm{C} 3-\mathrm{C} 4-\mathrm{C} 6\end{array}$ & $\begin{array}{l}\text { C11-В10-С9-C7/ } \\
\text { C12-B10-С9-C8 }\end{array}$ & $\begin{array}{l}\mathrm{N} 1-\mathrm{C} 3-\mathrm{C} 4-\mathrm{C} 5 / \\
\mathrm{N} 2-\mathrm{C} 3-\mathrm{C} 4-\mathrm{C} 6\end{array}$ & $\begin{array}{l}\text { C11-B10-С9-C7/ } \\
\text { C12-B10-С9-С8 }\end{array}$ & \\
\hline & $5^{\mathrm{DIP}}$ & & & & & \\
\hline 1 & (U)M062X/Def2SVP & $21.6 / 12$ & $14.1 / 13.8$ & $72 / 96$ & $21.3 / 21.9$ & -22.40 \\
\hline 2 & $\begin{array}{c}\text { (U)B3LYP/6- } \\
31 \mathrm{~g}(\mathrm{~d}, \mathrm{p})^{a}\end{array}$ & 21.5 & $11.8 / 11.7$ & 31.9 & 23.3 & -24.28 \\
\hline 3 & $\begin{array}{l}\text { (U)wB97XD/6- } \\
31 \mathrm{~g}(\mathrm{~d}, \mathrm{p})^{a}\end{array}$ & 24.8 & $9.8 / 9.7$ & $38.1 / 32.9$ & $24 / 24.2$ & -21.74 \\
\hline 4 & $\begin{array}{c}\text { (U)MN12SX/6- } \\
31 \mathrm{~g}(\mathrm{~d}, \mathrm{p})^{a}\end{array}$ & 26.5 & 10.5 & 33.9 & 24 & -21.76 \\
\hline \multirow[t]{2}{*}{5} & $\begin{array}{l}\text { (U)MN12L/6- } \\
31 \mathrm{~g}(\mathrm{~d}, \mathrm{p})^{a}\end{array}$ & 28.0 & 12.2 & 34.6 & 22 & -22.74 \\
\hline & $5^{\mathrm{iPr}}$ & & & & & \\
\hline 6 & $\begin{array}{l}(U) w B 97 X D / 6- \\
31 g(d, p)^{a}\end{array}$ & $11 . / 10.5$ & $9.5 / 9.3$ & $24.8 / 22.7$ & 29.9/29.7 & -23.62 \\
\hline 7 & $\begin{array}{l}\text { (U)wB97XD/6- } \\
31 \mathrm{~g}(\mathrm{~d}, \mathrm{p})^{a, b}\end{array}$ & $12.3 / 12.2$ & $0.3 / 1.1$ & $22.9 / 22.6$ & $23.2 / 28.3$ & -21.12 \\
\hline 8 & $\begin{array}{c}\text { (U)wB97XD/6- } \\
31 \mathrm{~g}(\mathrm{~d}, \mathrm{p})^{b, c, d}\end{array}$ & - & - & - & - & -8.99 \\
\hline
\end{tabular}

${ }^{a}$ Using X-ray geometry as a initial guess, the broken symmetry singlet (BSS) state was found to be isoenergetic with restricted singlet (RS) state. ${ }^{b} \mathrm{~A}$ Counter ion potassium encapsulated in 18-C-6 and two THF was included in geometry optimization. 'Single point energy calculation using the triplet optimized geometry in enty $7 .{ }^{d} \mathrm{BSS}$ state was calculated to be $4.9 \mathrm{kcal} \mathrm{mol}^{-1}$ lower in energy compared to RS state. 


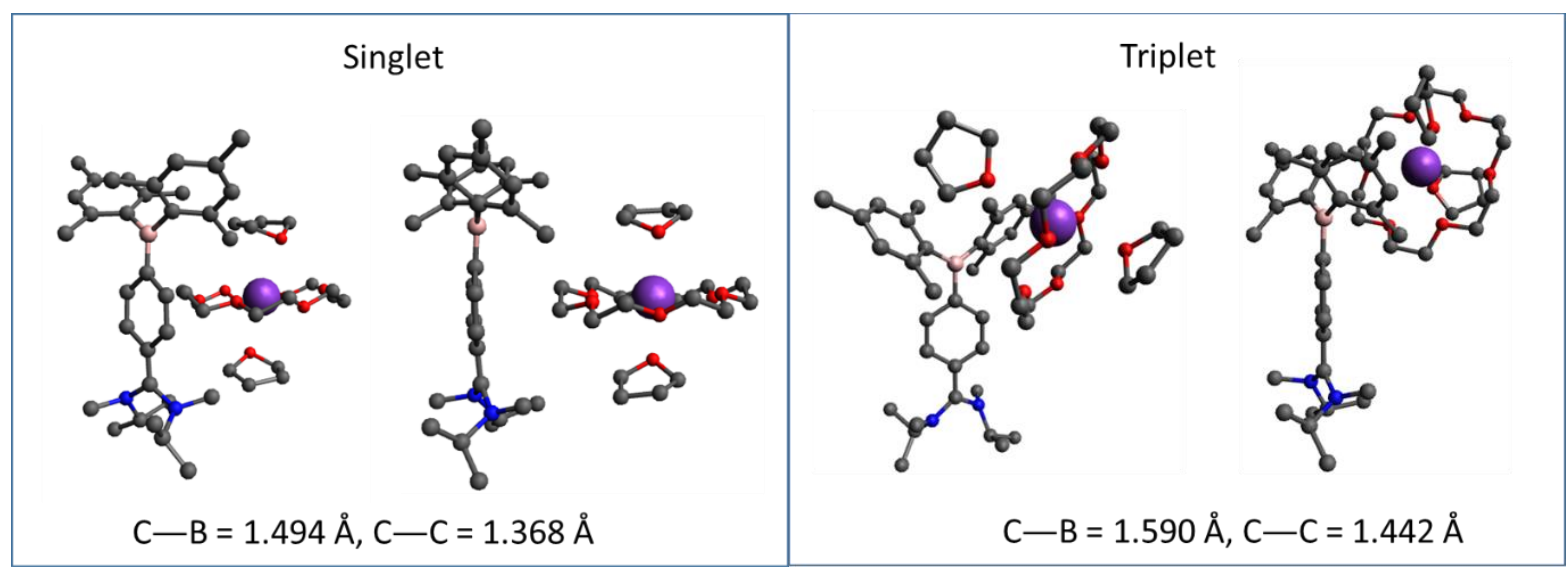

Figure S46. Optimized geometries (top and side views) of Singlet (left) and triplet (right) states of $\mathbf{5}^{\text {iPr }}$ including a counter ion potassium encapsulated in 18-C-6 and two THF as observed in single crystal structure.

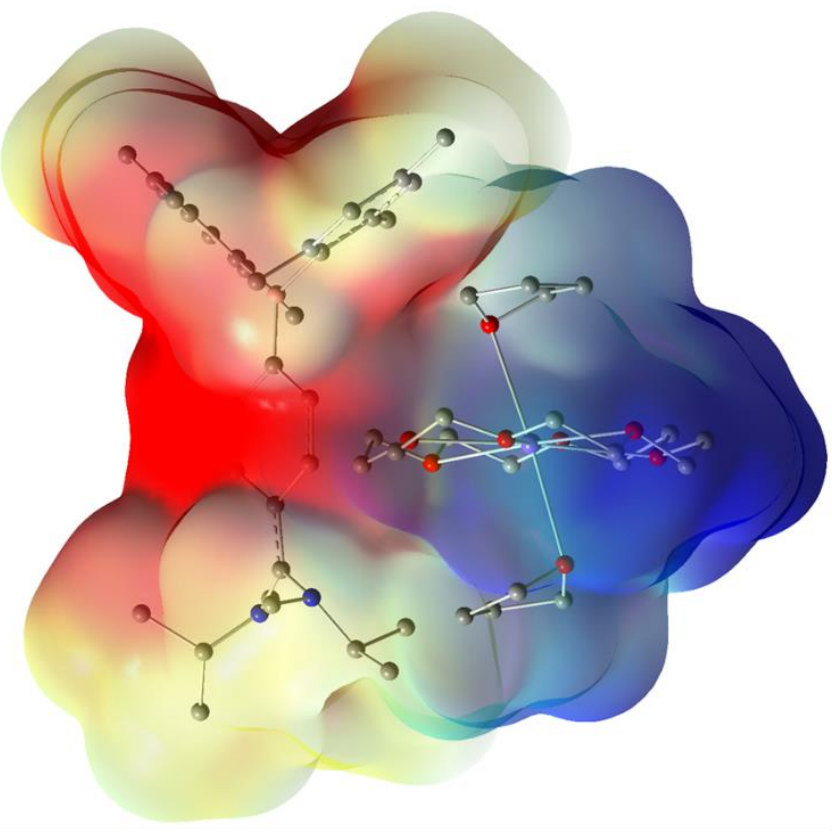

Singlet Geometry

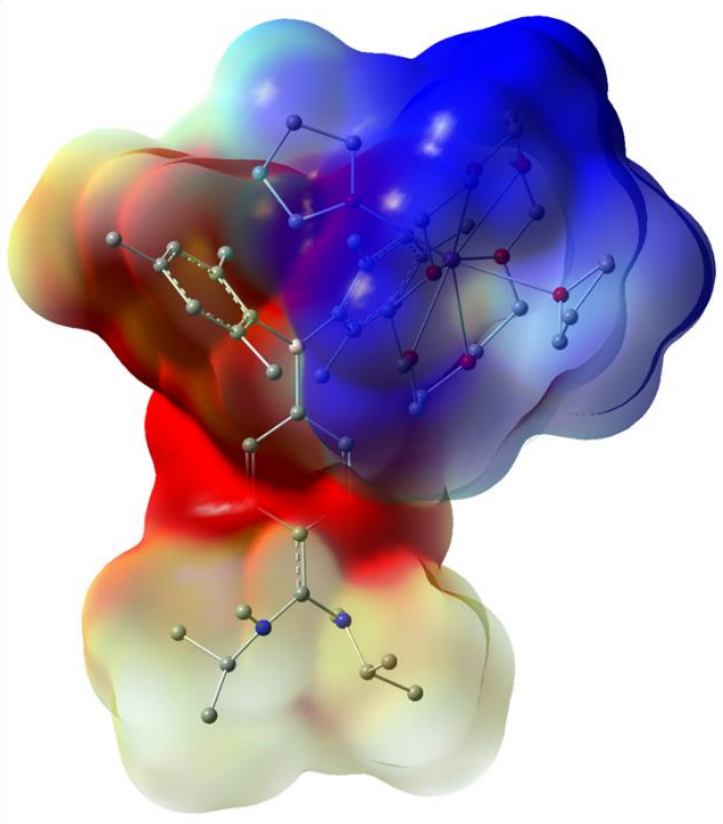

Triplet Geometry

Figure S47. Molecular Electrostatic Potential (MEP) surface of singlet (left) anf triplet (right) states of $\mathbf{5}^{\mathrm{iPr}}$ including a counter ion potassium encapsulated in 18-C-6 and two THF. 


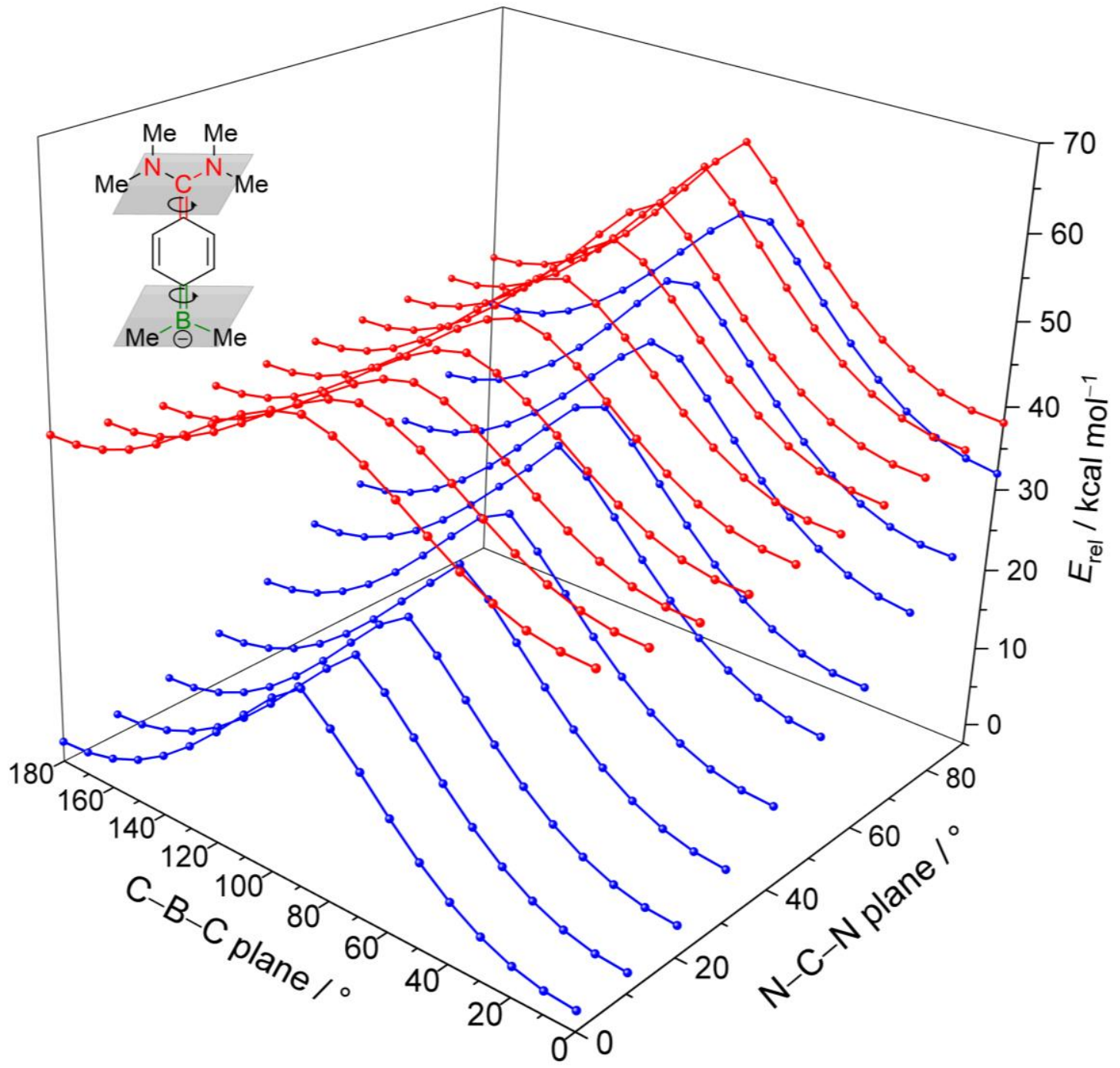

Figure S48. Relaxed potential energy scan of $\mathbf{5}$ (without counter ion and solvent) for the singlet (blue) and the triplet (red) states by varying the dihedral angle of $C-B-C$ and $N-C-N$ plane. PES were performed at UB3LYP/6-31g(d,p) level of DFT. 
a

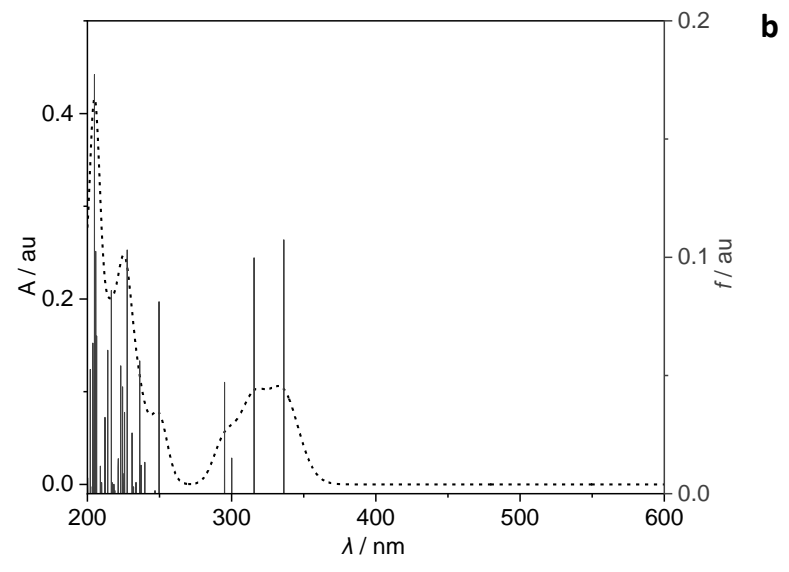

C

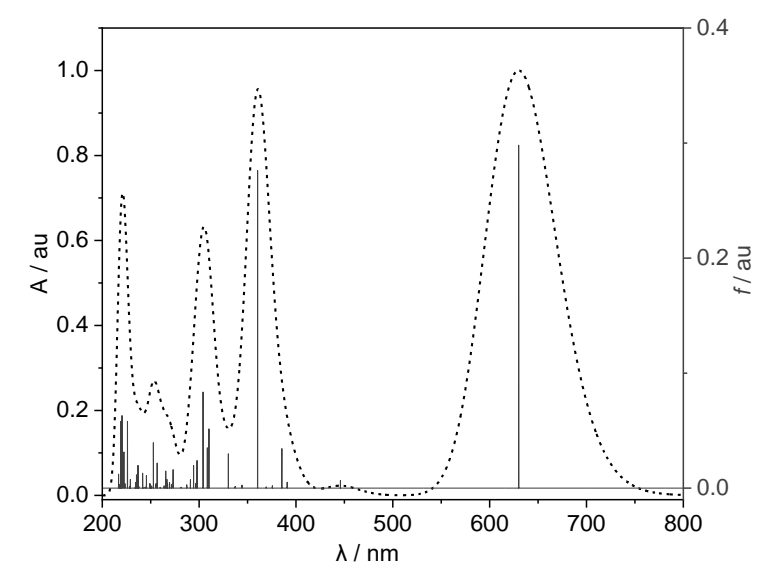

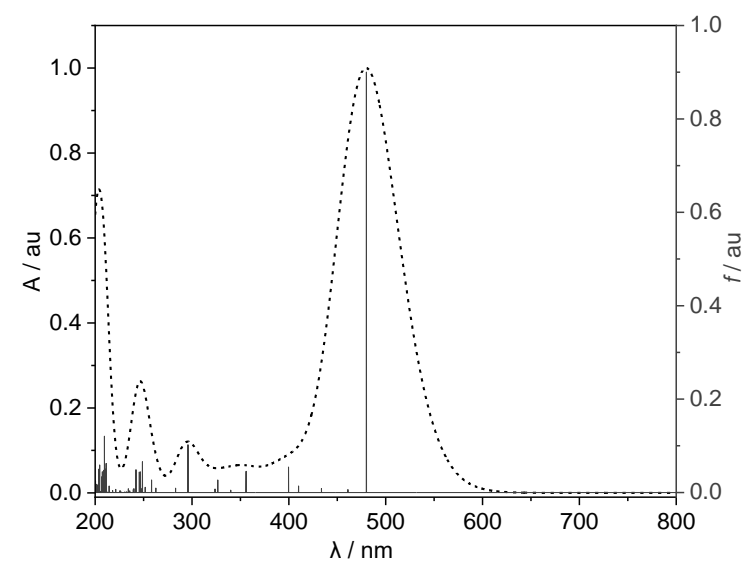

定

Figure S49. TD-DFT calculated electronic absorption spectra of (a) $4^{\mathrm{DIP}}$ (b) $5^{\mathrm{DIP}}$, and (c) $6^{\mathrm{DIP}} . f$ : oscillator strength. 
Table S9. Summary of TD-DFT calculated key low energy transitions.

\begin{tabular}{|c|c|c|c|c|c|}
\hline $\begin{array}{l}\text { Excited } \\
\text { singlet } \\
\text { state }\end{array}$ & $\begin{array}{c}\text { Wavelength } \\
(\mathrm{nm})\end{array}$ & $\begin{array}{c}\text { Energy } \\
(\mathrm{eV})\end{array}$ & Major transtions & Contribution & $\begin{array}{c}\text { oscillator } \\
\text { strength }(f)\end{array}$ \\
\hline \multicolumn{6}{|c|}{$4^{\mathrm{DIP}}$} \\
\hline \multirow{2}{*}{1} & \multirow{2}{*}{336.22} & \multirow{2}{*}{3.69} & $195->196$ & 0.64 & \multirow{2}{*}{0.10} \\
\hline & & & 195 -> 197 & 0.19 & \\
\hline \multirow{2}{*}{2} & \multirow{2}{*}{315.57} & \multirow{2}{*}{3.92} & 194 -> 196 & 0.63 & \multirow{2}{*}{0.09} \\
\hline & & & $194->197$ & 0.18 & \\
\hline \multirow{3}{*}{3} & \multirow{3}{*}{300.10} & \multirow{3}{*}{4.13} & $193->196$ & 0.64 & \multirow{3}{*}{0.015} \\
\hline & & & $193->197$ & 0.18 & \\
\hline & & & $193->201$ & 0.12 & \\
\hline \multicolumn{6}{|c|}{ HOMO: 195, LUMO: 196} \\
\hline \multicolumn{6}{|c|}{$5^{\mathrm{DIP}}$} \\
\hline 1 & 480.11 & 2.5824 & $196->197$ & 0.69 & 0.90 \\
\hline \multirow{3}{*}{2} & \multirow{3}{*}{461.00} & \multirow{3}{*}{2.69} & $196->198$ & 0.43 & \multirow{3}{*}{0.0063} \\
\hline & & & 196 -> 199 & 0.50 & \\
\hline & & & $196->201$ & 0.20 & \\
\hline \multirow{4}{*}{3} & \multirow{4}{*}{433.74} & \multirow{4}{*}{2.86} & $196->198$ & -0.26 & \multirow{4}{*}{0.0084} \\
\hline & & & $196->199$ & 0.27 & \\
\hline & & & $196->200$ & 0.59 & \\
\hline & & & $196->207$ & 0.11 & \\
\hline \multicolumn{6}{|c|}{ HOMO: 196, LUMO: 197} \\
\hline \multicolumn{6}{|c|}{$6^{\text {DIP }}$} \\
\hline 1 & 1.97 & 630.04 & $196 A->197 A$ & 0.95 & 0.30 \\
\hline \multirow{3}{*}{2} & \multirow{3}{*}{2.78} & \multirow{3}{*}{445.91} & $196 A->198 A$ & 0.71 & \multirow{3}{*}{0.0068} \\
\hline & & & $196 A->203 A$ & 0.50 & \\
\hline & & & $196 A->200 A$ & -0.36 & \\
\hline \multirow{3}{*}{3} & \multirow{3}{*}{3.17} & \multirow{3}{*}{390.87} & 196A -> 199A & 0.87 & \\
\hline & & & $196 A->201 A$ & -0.43 & 0.0052 \\
\hline & & & $196 A->200 A$ & -0.36 & \\
\hline
\end{tabular}


Mulliken charges (1) and spin densities (2) of $6^{\text {DIP }}$

$\begin{array}{llcc} & & 1 & 2 \\ 1 & C & 0.022463 & 0.155365 \\ 2 & C & -0.025349 & -0.080969 \\ 3 & C & 0.090585 & 0.193673 \\ 4 & C & -0.024789 & -0.080610 \\ 5 & C & 0.019866 & 0.155581 \\ 6 & C & 0.027339 & -0.066174 \\ 7 & C & 0.170483 & 0.388624 \\ 8 & N & -0.355881 & 0.061408 \\ 9 & C & 0.071509 & -0.009148 \\ 10 & B & -0.488824 & 0.185590 \\ 11 & N & -0.355137 & 0.064165 \\ 12 & C & 0.068212 & -0.009443 \\ 13 & C & -0.002464 & 0.016866 \\ 14 & C & -0.087739 & -0.005497 \\ 15 & C & 0.016811 & 0.011998 \\ 16 & C & -0.094147 & -0.003375 \\ 17 & C & 0.033597 & 0.011135 \\ 18 & C & 0.034211 & 0.011326 \\ 19 & C & -0.094133 & -0.003416 \\ 20 & C & 0.017082 & 0.011758 \\ 21 & C & -0.088044 & -0.005430 \\ 22 & C & -0.001536 & 0.016603 \\ 23 & C & -0.150566 & 0.002230 \\ 24 & C & -0.015310 & 0.000228 \\ 25 & C & -0.008911 & 0.000471 \\ 26 & C & -0.202977 & 0.000228 \\ 27 & C & -0.000886 & 0.000305 \\ 28 & C & -0.015376 & 0.000365 \\ 29 & C & -0.150833 & 0.002024 \\ 30 & C & -0.204371 & 0.000177 \\ 31 & C & -0.000215 & 0.000313 \\ 32 & C & -0.015482 & 0.000367 \\ 33 & C & -0.015155 & 0.000415 \\ 34 & C & -0.009620 & 0.000501 \\ 35 & C & 0.117733 & -0.023091 \\ 36 & C & -0.135798 & 0.004348 \\ 37 & C & -0.075532 & -0.001359 \\ 38 & C & -0.066707 & 0.002862 \\ 39 & C & -0.069683 & -0.001330 \\ 40 & C & -0.153197 & 0.005082 \\ 41 & C & 0.051273 & 0.000412 \\ 42 & C & 0.080411 & -0.002722 \\ 43 \text { C } & 0.007021 & -0.000217 \\ 44 & C & 0.096693 & 0.000557 \\ 45 & C & 0.117223 & -0.022902 \\ 46 & C & -0.135779 & 0.004280 \\ 47 & C & -0.075435 & -0.001297 \\ 48 & C & -0.066736 & 0.002751\end{array}$

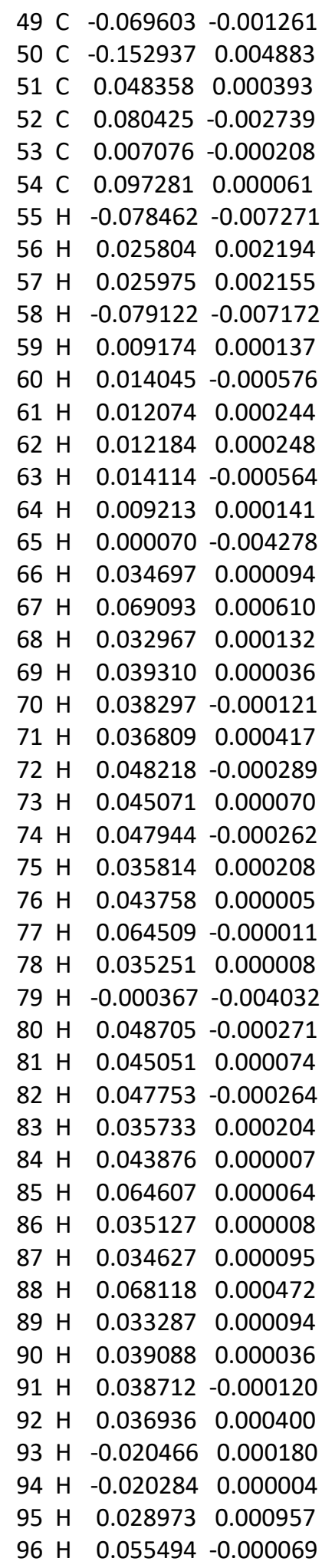

97 H $0.055769-0.001068$

$\begin{array}{llllll}98 & \mathrm{H} & 0.038037 & 0.000343\end{array}$

$\begin{array}{lllll}99 & \mathrm{H} & 0.024123 & 0.000036\end{array}$

$\begin{array}{lll}100 \mathrm{H} & 0.066477 & 0.000009\end{array}$

$\begin{array}{llll}101 \mathrm{H} & 0.034814 & 0.000002\end{array}$

$\begin{array}{llll}102 \mathrm{H} & 0.047902 & 0.000090\end{array}$

$\begin{array}{llll}103 & \text { H } & 0.055828 & 0.000138\end{array}$

$\begin{array}{lll}104 \mathrm{H} & 0.041213 & 0.003325\end{array}$

$\begin{array}{llll}105 \mathrm{H} & 0.046412 & 0.006639\end{array}$

106 H $0.057203 \quad-0.000440$

$107 \mathrm{H} \quad-0.020468 \quad 0.000180$

$\begin{array}{llll}108 \mathrm{H} & -0.020464 & 0.000002\end{array}$

109 H 0.0288790 .000900

$110 \mathrm{H} \quad 0.056723 \quad 0.000361$

$111 \mathrm{H} \quad 0.056809-0.001143$

$112 \mathrm{H} \quad 0.0383530 .000341$

$113 \mathrm{H} \quad 0.024138 \quad 0.000037$

$\begin{array}{llll}114 \mathrm{H} & 0.066508 & 0.000007\end{array}$

$\begin{array}{llll}115 \mathrm{H} & 0.034727 & 0.000002\end{array}$

$\begin{array}{llll}116 & \mathrm{H} & 0.047893 & 0.000087\end{array}$

$\begin{array}{llll}117 & \mathrm{H} & 0.055813 & 0.000132\end{array}$

$118 \mathrm{H} \quad 0.0457740 .006652$

119 H $0.057711-0.000414$

120 H 0.0415440 .003636

Sum of Mulliken charges $=0.00$

Sum of Mulliken spin density $=1.0$ 


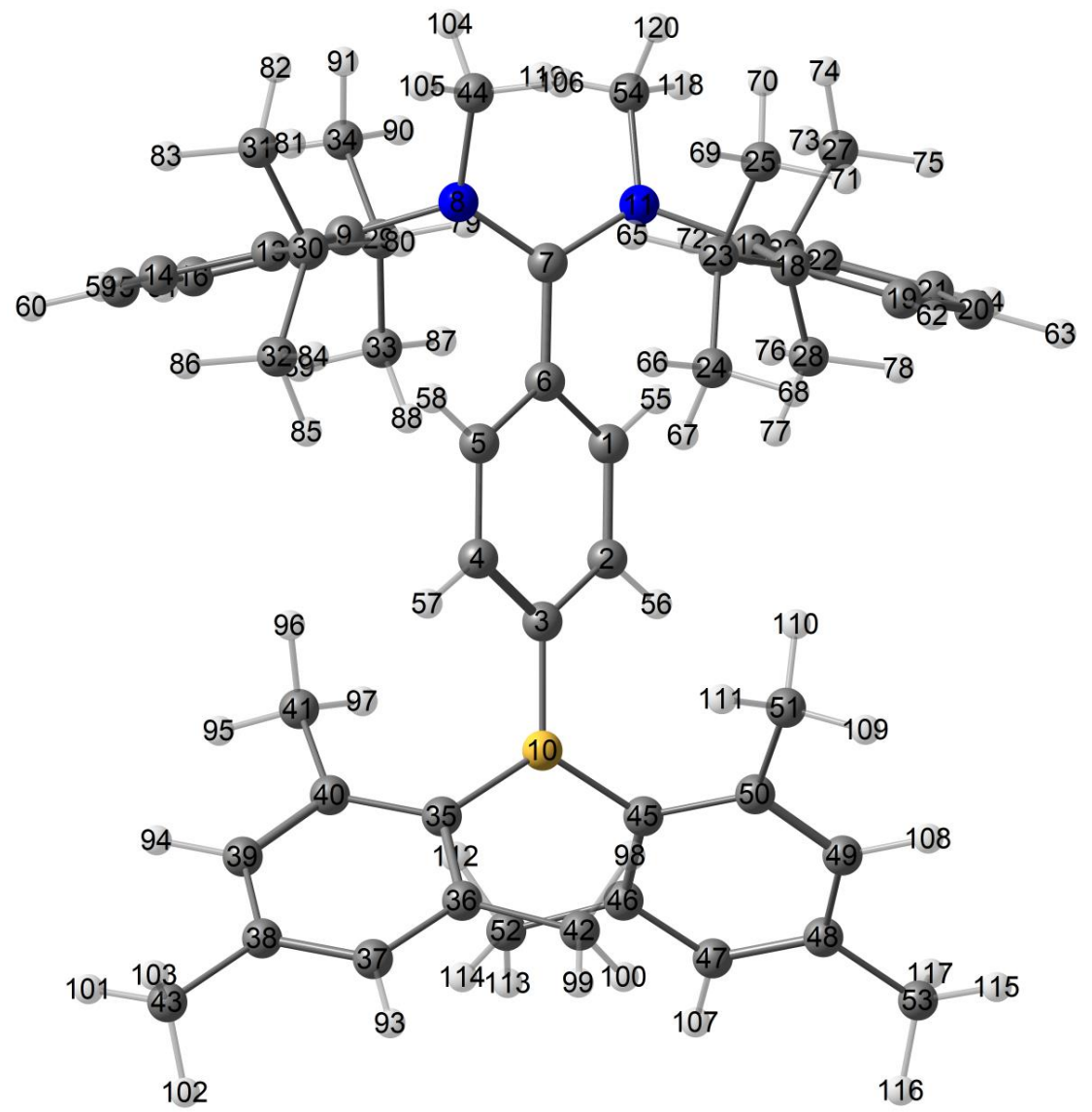

Figure S50. Optimized structure and numbering of atoms of $6^{\text {DIP. }}$. 
Table S10. Cartesian Coordinates

\begin{tabular}{|c|c|c|c|c|c|c|c|}
\hline \multicolumn{8}{|c|}{$4^{\mathrm{DIP}}$} \\
\hline \multicolumn{8}{|c|}{ RM062X/def2SVP, Total energy: -2114.89516530 hartree } \\
\hline C & 0.05599 & 1.23841 & 0.41028 & $\mathrm{H}$ & -0.55336 & -2.45788 & 4.52893 \\
\hline $\mathrm{C}$ & -1.33200 & 1.27887 & 0.31055 & $\mathrm{H}$ & 0.06521 & -3.81512 & 2.55733 \\
\hline $\mathrm{C}$ & -2.03439 & 0.33387 & -0.45426 & $\mathrm{H}$ & 7.16979 & 2.47373 & -0.53071 \\
\hline C & -1.29519 & -0.62123 & -1.16913 & $\mathrm{H}$ & 8.22779 & 0.56123 & -1.68920 \\
\hline C & 0.09603 & -0.64831 & -1.11418 & $\mathrm{H}$ & 6.84049 & -1.25182 & -2.64029 \\
\hline C & 0.76492 & 0.26202 & -0.29291 & $\mathrm{H}$ & 2.17696 & -2.53798 & -0.26300 \\
\hline C & 2.25307 & 0.17854 & -0.18106 & $\mathrm{H}$ & 3.18091 & -4.78797 & 0.13303 \\
\hline$N$ & 2.74634 & -0.45880 & 0.87991 & $\mathrm{H}$ & 3.74139 & -3.61686 & 1.35484 \\
\hline C & 1.82287 & -0.99995 & 1.86849 & $\mathrm{H}$ & 2.49180 & -4.80557 & 1.77428 \\
\hline B & -3.61895 & 0.30793 & -0.46049 & $\mathrm{H}$ & -0.26800 & -3.30642 & -0.31816 \\
\hline$N$ & 2.95956 & 0.73319 & -1.16293 & $\mathrm{H}$ & 0.23078 & -4.75105 & 0.58983 \\
\hline C & 4.39974 & 0.67552 & -1.29304 & $\mathrm{H}$ & 0.90503 & -4.45602 & -1.01726 \\
\hline C & 1.50936 & -0.21511 & 2.99194 & $\mathrm{H}$ & 2.47382 & 1.54602 & 2.25381 \\
\hline C & 0.64180 & -0.76644 & 3.93914 & $\mathrm{H}$ & 1.52227 & 3.18275 & 3.75646 \\
\hline C & 0.12273 & -2.04706 & 3.77801 & $\mathrm{H}$ & 0.15874 & 2.16912 & 3.20687 \\
\hline C & 0.47039 & -2.80808 & 2.66710 & $\mathrm{H}$ & 0.85036 & 1.94620 & 4.82566 \\
\hline C & 1.33209 & -2.30397 & 1.68813 & $\mathrm{H}$ & 3.01226 & 0.66806 & 5.14047 \\
\hline C & 5.15798 & 1.74080 & -0.77832 & $\mathrm{H}$ & 3.75843 & 2.06560 & 4.32934 \\
\hline C & 6.54565 & 1.67135 & -0.92885 & $\mathrm{H}$ & 4.10705 & 0.41182 & 3.76749 \\
\hline C & 7.14289 & 0.59708 & -1.58316 & $\mathrm{H}$ & 3.43794 & 2.76711 & -0.02778 \\
\hline C & 6.36077 & -0.42399 & -2.11482 & $\mathrm{H}$ & 4.53244 & 3.97133 & 1.82340 \\
\hline C & 4.96817 & -0.40359 & -1.98907 & $\mathrm{H}$ & 4.87386 & 2.23330 & 1.96461 \\
\hline C & 1.75399 & -3.18504 & 0.52322 & $\mathrm{H}$ & 6.12143 & 3.34037 & 1.35012 \\
\hline C & 2.86036 & -4.15118 & 0.97034 & $\mathrm{H}$ & 4.24106 & 5.06893 & -0.44209 \\
\hline$C$ & 0.58475 & -3.96143 & -0.08874 & $\mathrm{H}$ & 4.37165 & 4.10966 & -1.93769 \\
\hline$C$ & 2.11158 & 1.16284 & 3.22302 & $\mathrm{H}$ & 5.82139 & 4.45327 & -0.97288 \\
\hline$C$ & 1.09811 & 2.16883 & 3.77787 & $\mathrm{H}$ & 3.08413 & -1.36612 & -2.29282 \\
\hline$C$ & 3.32149 & 1.06993 & 4.16415 & $\mathrm{H}$ & 3.52733 & -2.19642 & -4.58355 \\
\hline$C$ & 4.52451 & 2.93960 & -0.08822 & $\mathrm{H}$ & 3.85519 & -0.44484 & -4.49827 \\
\hline $\mathrm{C}$ & 5.04304 & 3.12451 & 1.34223 & $\mathrm{H}$ & 5.20071 & -1.60202 & -4.50081 \\
\hline$C$ & 4.74938 & 4.21457 & -0.91074 & $\mathrm{H}$ & 3.88617 & -3.67030 & -2.53168 \\
\hline$C$ & 4.13076 & -1.51385 & -2.60460 & $\mathrm{H}$ & 4.53890 & -2.98605 & -1.02636 \\
\hline$C$ & 4.17713 & -1.43131 & -4.13555 & $\mathrm{H}$ & 5.57843 & -3.14624 & -2.45995 \\
\hline$C$ & 4.56027 & -2.90318 & -2.12303 & $\mathrm{H}$ & -6.67786 & -2.78089 & -2.34621 \\
\hline$C$ & -4.31260 & -1.09865 & -0.53996 & $\mathrm{H}$ & -4.30633 & -4.18018 & 0.94222 \\
\hline C & -5.32367 & -1.33947 & -1.50263 & $\mathrm{H}$ & -2.97208 & -0.96712 & 1.90293 \\
\hline$C$ & -5.91095 & -2.60221 & -1.58757 & $\mathrm{H}$ & -3.05027 & -2.71153 & 2.21937 \\
\hline $\mathrm{C}$ & -5.55697 & -3.64083 & -0.72149 & $\mathrm{H}$ & -1.88443 & -2.06079 & 1.04977 \\
\hline$C$ & -4.57898 & -3.38704 & 0.24071 & $\mathrm{H}$ & -6.42596 & -0.68054 & -3.23848 \\
\hline$C$ & -3.94535 & -2.14486 & 0.33817 & $\mathrm{H}$ & -6.38513 & 0.50294 & -1.91007 \\
\hline $\mathrm{C}$ & -2.91299 & -1.95906 & 1.43080 & $\mathrm{H}$ & -4.96064 & 0.27290 & -2.92573 \\
\hline$C$ & -5.79633 & -0.25694 & -2.44584 & $\mathrm{H}$ & -6.17539 & -5.37750 & -1.84350 \\
\hline$C$ & -6.23370 & -4.98155 & -0.81956 & $\mathrm{H}$ & -5.77744 & -5.71273 & -0.14026 \\
\hline$C$ & 4.16547 & -0.71822 & 1.17826 & $\mathrm{H}$ & -7.30037 & -4.89856 & -0.56317 \\
\hline$C$ & -4.40493 & 1.66194 & -0.36766 & $\mathrm{H}$ & 4.63306 & -1.32263 & 0.39229 \\
\hline$C$ & -5.46064 & 1.81324 & 0.56739 & $\mathrm{H}$ & 4.72974 & 0.21438 & 1.29183 \\
\hline$C$ & -6.14052 & 3.02818 & 0.65166 & $\mathrm{H}$ & 4.19246 & -1.27366 & 2.12080 \\
\hline$C$ & -5.83884 & 4.10442 & -0.18826 & $\mathrm{H}$ & -6.94162 & 3.13790 & 1.38772 \\
\hline$C$ & -4.81889 & 3.93802 & -1.12504 & $\mathrm{H}$ & -4.58598 & 4.75900 & -1.80834 \\
\hline$C$ & -4.09281 & 2.74739 & -1.21909 & $\mathrm{H}$ & -3.20098 & 3.39624 & -3.07365 \\
\hline$C$ & -3.01778 & 2.65852 & -2.28147 & $\mathrm{H}$ & -2.01993 & 2.86067 & -1.86215 \\
\hline$C$ & -5.88741 & 0.68790 & 1.48192 & $\mathrm{H}$ & -2.97256 & 1.66604 & -2.75207 \\
\hline$C$ & -6.60234 & 5.39646 & -0.07820 & $\mathrm{H}$ & -5.03299 & 0.19741 & 1.96944 \\
\hline$C$ & 2.29838 & 1.43144 & -2.27949 & $\mathrm{H}$ & -6.55575 & 1.06177 & 2.26792 \\
\hline $\mathrm{H}$ & 0.58956 & 1.96225 & 1.02914 & $\mathrm{H}$ & -6.42248 & -0.09404 & 0.92211 \\
\hline $\mathrm{H}$ & -1.89056 & 2.05057 & 0.84752 & $\mathrm{H}$ & -6.42362 & 5.87233 & 0.89750 \\
\hline $\mathrm{H}$ & -1.82578 & -1.36847 & -1.76549 & $\mathrm{H}$ & -6.30792 & 6.10540 & -0.86226 \\
\hline $\mathrm{H}$ & 0.65670 & -1.39706 & -1.67978 & $\mathrm{H}$ & -7.68448 & 5.22079 & -0.16089 \\
\hline $\mathrm{H}$ & 0.36956 & -0.18433 & 4.82041 & $\mathrm{H}$ & 2.99700 & 2.18992 & -2.64984 \\
\hline & & & & $\mathrm{H}$ & 2.07257 & 0.72558 & -3.09281 \\
\hline & & & & $\mathrm{H}$ & 1.37268 & 1.91354 & -1.95121 \\
\hline
\end{tabular}




\begin{tabular}{|c|c|c|c|}
\hline \multicolumn{4}{|c|}{$5^{\mathrm{DIP}}-$ Singlet } \\
\hline \multicolumn{4}{|c|}{ UM062X/def2SVP, Total energy: -2115.0774929 hartree } \\
\hline C & -0.01065 & 1.29700 & -0.11762 \\
\hline C & -1.36905 & 1.15045 & -0.15720 \\
\hline $\mathrm{C}$ & -2.04912 & -0.09526 & -0.37626 \\
\hline C & -1.15436 & -1.18650 & -0.63866 \\
\hline C & 0.20497 & -1.06926 & -0.65152 \\
\hline $\mathrm{C}$ & 0.90639 & 0.17305 & -0.31836 \\
\hline C & 2.29456 & 0.17940 & -0.28443 \\
\hline $\mathrm{N}$ & 3.13865 & 1.25662 & 0.19707 \\
\hline C & 2.54352 & 2.40269 & 0.82412 \\
\hline B & -3.54070 & -0.24218 & -0.34194 \\
\hline $\mathrm{N}$ & 2.99448 & -0.84276 & -1.01003 \\
\hline C & 3.97724 & -1.73356 & -0.50122 \\
\hline C & 2.54311 & 3.63363 & 0.12907 \\
\hline $\mathrm{C}$ & 1.98456 & 4.75765 & 0.74582 \\
\hline $\mathrm{C}$ & 1.43929 & 4.68794 & 2.02368 \\
\hline $\mathrm{C}$ & 1.44935 & 3.47604 & 2.70114 \\
\hline $\mathrm{C}$ & 1.98977 & 2.32379 & 2.12028 \\
\hline C & 5.23401 & -1.89060 & -1.16531 \\
\hline C & 6.14358 & -2.83909 & -0.67603 \\
\hline $\mathrm{C}$ & 5.89395 & -3.60443 & 0.45222 \\
\hline $\mathrm{C}$ & 4.68817 & -3.42207 & 1.11462 \\
\hline C & 3.72395 & -2.51958 & 0.65911 \\
\hline $\mathrm{C}$ & 5.77090 & -1.10741 & -2.37611 \\
\hline $\mathrm{C}$ & 5.47680 & -1.77273 & -3.73308 \\
\hline $\mathrm{C}$ & 5.53736 & 0.41043 & -2.36829 \\
\hline $\mathrm{C}$ & 2.39113 & -2.52016 & 1.39496 \\
\hline $\mathrm{C}$ & 1.58579 & -3.76998 & 1.01845 \\
\hline $\mathrm{C}$ & 2.55906 & -2.43928 & 2.91580 \\
\hline C & 3.10704 & 3.80554 & -1.27427 \\
\hline C & 4.63121 & 3.66039 & -1.29774 \\
\hline C & 2.42117 & 2.92375 & -2.32182 \\
\hline $\mathrm{C}$ & 1.92355 & 1.02353 & 2.90724 \\
\hline C & 2.83089 & 1.09186 & 4.14074 \\
\hline$C$ & 0.48675 & 0.66518 & 3.30294 \\
\hline$C$ & -4.22748 & -1.69116 & -0.26624 \\
\hline C & -3.90891 & -2.60524 & 0.76765 \\
\hline $\mathrm{C}$ & -4.56734 & -3.83997 & 0.84755 \\
\hline $\mathrm{C}$ & -5.53600 & -4.22451 & -0.07691 \\
\hline $\mathrm{C}$ & -5.85034 & -3.32365 & -1.09620 \\
\hline$C$ & -5.22458 & -2.07852 & -1.19479 \\
\hline C & -5.64646 & -1.15365 & -2.31249 \\
\hline $\mathrm{C}$ & -2.87959 & -2.29947 & 1.83318 \\
\hline C & -6.20465 & -5.57356 & 0.00084 \\
\hline$C$ & 4.38361 & 0.86717 & 0.84791 \\
\hline $\mathrm{C}$ & -4.50733 & 1.03923 & -0.36936 \\
\hline $\mathrm{C}$ & -4.44368 & 1.99002 & -1.41688 \\
\hline $\mathrm{C}$ & -5.34141 & 3.06543 & -1.45163 \\
\hline $\mathrm{C}$ & -6.30964 & 3.25429 & -0.46768 \\
\hline $\mathrm{C}$ & -6.37234 & 2.31755 & 0.56550 \\
\hline C & -5.50264 & 1.22542 & 0.62070 \\
\hline C & -5.65812 & 0.24526 & 1.75973 \\
\hline C & -3.43797 & 1.88878 & -2.54181 \\
\hline C & -7.23882 & 4.44123 & -0.49894 \\
\hline C & 2.63707 & -0.99223 & -2.41366 \\
\hline $\mathrm{H}$ & 0.37058 & 2.29946 & 0.04508 \\
\hline $\mathrm{H}$ & -1.97922 & 2.04535 & 0.00816 \\
\hline $\mathrm{H}$ & -1.58804 & -2.16889 & -0.85849 \\
\hline $\mathrm{H}$ & 0.80208 & -1.95252 & -0.87409 \\
\hline $\mathrm{H}$ & 1.97469 & 5.70553 & 0.20242 \\
\hline $\mathrm{H}$ & 1.00220 & 5.57514 & 2.48552 \\
\hline $\mathrm{H}$ & 1.01154 & 3.41294 & 3.70008 \\
\hline $\mathrm{H}$ & 7.09845 & -2.95271 & -1.19643 \\
\hline
\end{tabular}

\begin{tabular}{|c|c|c|c|}
\hline & 6.62948 & -4.32547 & 0.81238 \\
\hline & 4.46648 & -4.02388 & 1.99809 \\
\hline & 6.86161 & -1.21761 & -2.27549 \\
\hline & 4.43765 & -1.66537 & -4.06023 \\
\hline & 6.11770 & -1.32217 & -4.50706 \\
\hline & 5.70890 & -2.84709 & -3.68471 \\
\hline & 4.53176 & 0.69968 & -2.04213 \\
\hline & 5.71276 & 0.82929 & -3.37154 \\
\hline & 6.24635 & 0.89885 & -1.68377 \\
\hline & 1.81441 & -1.64379 & 1.08456 \\
\hline & 0.57749 & -3.72635 & 1.45726 \\
\hline & 1.47813 & -3.86117 & -0.07152 \\
\hline & 2.08798 & -4.68112 & 1.38364 \\
\hline & 1.58049 & -2.28000 & 3.39277 \\
\hline & 3.22110 & -1.60892 & 3.20325 \\
\hline 7 & 2.97973 & -3.36616 & 3.33570 \\
\hline 7 & 2.88505 & 4.85058 & -1.54947 \\
\hline 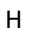 & 5.02201 & 3.84107 & -2.31190 \\
\hline | & 5.10287 & 4.38075 & -0.61227 \\
\hline 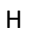 & 4.92537 & 2.64898 & -0.99375 \\
\hline$t$ & 2.78250 & 3.18582 & -3.32908 \\
\hline$t$ & 1.32989 & 3.05940 & -2.29798 \\
\hline | & 2.62238 & 1.86021 & -2.14347 \\
\hline$t$ & 2.27861 & 0.21961 & 2.25226 \\
\hline 7 & 2.79435 & 0.14583 & 4.70277 \\
\hline$\Rightarrow$ & 3.87635 & 1.28966 & 3.86013 \\
\hline 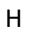 & 2.50674 & 1.89738 & 4.81890 \\
\hline$\Rightarrow$ & 0.47312 & -0.29834 & 3.83496 \\
\hline & -0.15649 & 0.58380 & 2.41514 \\
\hline H & 0.05404 & 1.42037 & 3.97816 \\
\hline H & -4.31368 & -4.52188 & 1.66567 \\
\hline 4 & -6.61036 & -3.59724 & -1.83548 \\
\hline H & -6.22769 & -1.69547 & -3.07228 \\
\hline 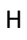 & -6.26177 & -0.32390 & -1.93151 \\
\hline - & -4.77536 & -0.69705 & -2.80328 \\
\hline H & -2.86896 & -1.23575 & 2.10404 \\
\hline - & -3.06731 & -2.90118 & 2.73452 \\
\hline - & -1.86118 & -2.52198 & 1.47856 \\
\hline - & -5.73082 & -6.29253 & -0.68695 \\
\hline 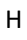 & -6.13799 & -5.99318 & 1.01448 \\
\hline 4 & -7.26734 & -5.50950 & -0.27535 \\
\hline 4 & 4.25252 & 0.13534 & 1.66904 \\
\hline 4 & 5.08472 & 0.42133 & 0.13229 \\
\hline 4 & 4.85384 & 1.77094 & 1.26017 \\
\hline 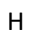 & -5.28077 & 3.77758 & -2.28107 \\
\hline H & -7.12516 & 2.43837 & 1.35137 \\
\hline H & -6.29126 & 0.66425 & 2.55483 \\
\hline t & -6.11181 & -0.69694 & 1.41532 \\
\hline - & -4.68375 & -0.01717 & 2.19558 \\
\hline - & -3.22034 & 0.84641 & -2.80797 \\
\hline - & -3.80041 & 2.42225 & -3.43281 \\
\hline - & -2.47080 & 2.32742 & -2.25140 \\
\hline - & -8.23701 & 4.17765 & -0.12003 \\
\hline t & -6.85640 & 5.26219 & 0.12904 \\
\hline$y$ & -7.35120 & 4.83238 & -1.52001 \\
\hline t & 1.56363 & -0.80695 & -2.54662 \\
\hline $\mathrm{H}$ & 3.17912 & -0.30386 & -3.08375 \\
\hline $\mathrm{H}$ & 2.83821 & -2.02466 & -2.73630 \\
\hline
\end{tabular}




\begin{tabular}{|c|c|c|c|c|c|c|c|}
\hline \multicolumn{8}{|c|}{$5^{\text {DIP }}$-Triplet } \\
\hline \multicolumn{8}{|c|}{ UM062X/def2SVP, Total energy: -2115.0417547 hartree } \\
\hline $\mathrm{C}$ & 0.14709 & 1.34392 & 0.42270 & $\mathrm{H}$ & 7.80257 & 0.88645 & -1.40608 \\
\hline $\mathrm{C}$ & -1.23494 & 1.37857 & 0.32831 & $\mathrm{H}$ & 7.58138 & -0.90822 & -3.10385 \\
\hline $\mathrm{C}$ & -1.99312 & 0.36240 & -0.31935 & $\mathrm{H}$ & 5.31258 & -1.64981 & -3.80658 \\
\hline $\mathrm{C}$ & -1.20559 & -0.66705 & -0.90761 & $\mathrm{H}$ & 6.93676 & 1.93140 & 0.41246 \\
\hline $\mathrm{C}$ & 0.17826 & -0.69439 & -0.82453 & $\mathrm{H}$ & 5.47549 & 3.83995 & -1.48093 \\
\hline $\mathrm{C}$ & 0.91172 & 0.29380 & -0.13457 & $\mathrm{H}$ & 6.67734 & 4.30902 & -0.25507 \\
\hline $\mathrm{C}$ & 2.39187 & 0.17085 & 0.01810 & $\mathrm{H}$ & 7.15953 & 3.29573 & -1.64415 \\
\hline$N$ & 2.90490 & -0.40715 & 1.22034 & $\mathrm{H}$ & 4.14297 & 3.14748 & 0.58565 \\
\hline$C$ & 1.96883 & -0.97695 & 2.15875 & $\mathrm{H}$ & 5.49901 & 3.24986 & 1.72787 \\
\hline B & -3.53900 & 0.36169 & -0.36150 & $\mathrm{H}$ & 4.61104 & 1.71828 & 1.50555 \\
\hline $\mathrm{N}$ & 3.24979 & 1.06904 & -0.68573 & $\mathrm{H}$ & 2.14672 & -0.32022 & -2.35123 \\
\hline$C$ & 4.40913 & 0.58104 & -1.37768 & $\mathrm{H}$ & 1.74539 & -0.43747 & -4.77350 \\
\hline$C$ & 1.67552 & -0.28640 & 3.35764 & $\mathrm{H}$ & 2.88804 & 0.87899 & -4.40276 \\
\hline$C$ & 0.69275 & -0.80669 & 4.20855 & $\mathrm{H}$ & 3.48828 & -0.65018 & -5.08700 \\
\hline C & 0.02862 & -1.99139 & 3.91863 & $\mathrm{H}$ & 1.67988 & -2.53055 & -3.28378 \\
\hline C & 0.38476 & -2.70786 & 2.78343 & $\mathrm{H}$ & 2.85799 & -2.70250 & -1.95746 \\
\hline C & 1.35922 & -2.22821 & 1.90386 & $\mathrm{H}$ & 3.39854 & -2.80043 & -3.65056 \\
\hline $\mathrm{C}$ & 5.69104 & 1.08191 & -1.05252 & $\mathrm{H}$ & 1.98765 & 1.16718 & 4.83850 \\
\hline$C$ & 6.81005 & 0.52139 & -1.68521 & $\mathrm{H}$ & 4.38295 & 1.52008 & 4.59514 \\
\hline C & 6.69173 & -0.47894 & -2.63962 & $\mathrm{H}$ & 4.02971 & -0.22290 & 4.73998 \\
\hline$C$ & 5.42233 & -0.90445 & -3.01521 & $\mathrm{H}$ & 4.44460 & 0.47767 & 3.15945 \\
\hline$C$ & 4.27713 & -0.37591 & -2.41469 & $\mathrm{H}$ & 2.79891 & 3.04387 & 3.42683 \\
\hline$C$ & 6.00978 & 2.23833 & -0.10209 & $\mathrm{H}$ & 1.15518 & 2.49663 & 3.00041 \\
\hline $\mathrm{C}$ & 6.35633 & 3.49249 & -0.92003 & $\mathrm{H}$ & 2.53729 & 2.04966 & 1.97028 \\
\hline $\mathrm{C}$ & 5.00452 & 2.59921 & 0.98881 & $\mathrm{H}$ & 2.23576 & -2.43878 & -0.01294 \\
\hline $\mathrm{C}$ & 2.92276 & -0.77376 & -2.97590 & $\mathrm{H}$ & 3.19005 & -4.71899 & 0.32871 \\
\hline $\mathrm{C}$ & 2.75301 & -0.21238 & -4.39301 & $\mathrm{H}$ & 3.71474 & -3.63892 & 1.64546 \\
\hline $\mathrm{C}$ & 2.70507 & -2.28820 & -2.96486 & $\mathrm{H}$ & 2.40931 & -4.80973 & 1.92879 \\
\hline$C$ & 2.42167 & 0.95042 & 3.84860 & $\mathrm{H}$ & 0.95149 & -4.27593 & -0.88895 \\
\hline$C$ & 3.90629 & 0.66134 & 4.09676 & $\mathrm{H}$ & -0.23636 & -3.19718 & -0.11018 \\
\hline$C$ & 2.21517 & 2.20886 & 3.00677 & $\mathrm{H}$ & 0.28570 & -4.69662 & 0.69747 \\
\hline$C$ & 1.78362 & -3.10317 & 0.73577 & $\mathrm{H}$ & -4.57128 & -4.22070 & 0.58734 \\
\hline$C$ & 2.84251 & -4.12101 & 1.18627 & $\mathrm{H}$ & -6.81960 & -2.34737 & -2.54704 \\
\hline$C$ & 0.62346 & -3.85414 & 0.07400 & $\mathrm{H}$ & -6.34565 & -0.23043 & -3.28855 \\
\hline$C$ & -4.31910 & -1.00833 & -0.60565 & $\mathrm{H}$ & -6.25765 & 0.83964 & -1.86245 \\
\hline $\mathrm{C}$ & -4.06498 & -2.16773 & 0.17729 & $\mathrm{H}$ & -4.81473 & 0.57600 & -2.83307 \\
\hline $\mathrm{C}$ & -4.78328 & -3.34925 & -0.04149 & $\mathrm{H}$ & -3.14752 & -1.24477 & 1.91178 \\
\hline $\mathrm{C}$ & -5.77328 & -3.44664 & -1.01888 & $\mathrm{H}$ & -3.19452 & -3.03477 & 1.95617 \\
\hline $\mathrm{C}$ & -6.04207 & -2.30476 & -1.77659 & $\mathrm{H}$ & -2.02171 & -2.15992 & 0.93688 \\
\hline$C$ & -5.34471 & -1.10929 & -1.58352 & $\mathrm{H}$ & -6.05556 & -5.31057 & -2.09142 \\
\hline $\mathrm{C}$ & -5.71397 & 0.07715 & -2.44224 & $\mathrm{H}$ & -6.49538 & -5.38197 & -0.37401 \\
\hline$C$ & -3.05949 & -2.15833 & 1.30448 & $\mathrm{H}$ & -7.56060 & -4.55506 & -1.53700 \\
\hline$C$ & -6.51036 & -4.73857 & -1.26564 & $\mathrm{H}$ & 4.32126 & -1.72702 & 0.31526 \\
\hline$C$ & 4.21903 & -1.02563 & 1.16618 & $\mathrm{H}$ & 5.01462 & -0.27254 & 1.05848 \\
\hline $\mathrm{C}$ & -4.36037 & 1.71216 & -0.15255 & $\mathrm{H}$ & 4.39648 & -1.56872 & 2.10350 \\
\hline $\mathrm{C}$ & -4.07623 & 2.89053 & -0.89496 & $\mathrm{H}$ & -4.59610 & 4.93903 & -1.31233 \\
\hline $\mathrm{C}$ & -4.83564 & 4.05314 & -0.71433 & $\mathrm{H}$ & -7.02737 & 2.96713 & 1.61755 \\
\hline $\mathrm{C}$ & -5.89752 & 4.11372 & 0.18641 & $\mathrm{H}$ & -6.55959 & 0.86092 & 2.36933 \\
\hline $\mathrm{C}$ & -6.19478 & 2.95360 & 0.90575 & $\mathrm{H}$ & -6.35355 & -0.19191 & 0.94292 \\
\hline $\mathrm{C}$ & -5.45896 & 1.77687 & 0.74874 & $\mathrm{H}$ & -4.98681 & 0.08636 & 2.01448 \\
\hline$C$ & -5.86512 & 0.57349 & 1.56627 & $\mathrm{H}$ & -2.99015 & 2.00609 & -2.54607 \\
\hline$C$ & -2.98703 & 2.92475 & -1.94058 & $\mathrm{H}$ & -3.11233 & 3.79279 & -2.60450 \\
\hline$C$ & -6.68493 & 5.38249 & 0.39443 & $\mathrm{H}$ & -1.98496 & 2.97871 & -1.48812 \\
\hline$C$ & 2.64156 & 2.23892 & -1.29965 & $\mathrm{H}$ & -7.76147 & 5.17563 & 0.49044 \\
\hline $\mathrm{H}$ & 0.65208 & 2.14870 & 0.95585 & $\mathrm{H}$ & -6.37166 & 5.90519 & 1.31333 \\
\hline $\mathrm{H}$ & -1.77363 & 2.20801 & 0.79798 & $\mathrm{H}$ & -6.54506 & 6.07904 & -0.44469 \\
\hline $\mathrm{H}$ & -1.71747 & -1.46847 & -1.45121 & $\mathrm{H}$ & 1.87510 & 1.97886 & -2.05341 \\
\hline $\mathrm{H}$ & 0.71988 & -1.51550 & -1.29858 & $\mathrm{H}$ & 2.15568 & 2.87313 & -0.54391 \\
\hline $\mathrm{H}$ & 0.44890 & -0.26002 & 5.12234 & $\mathrm{H}$ & 3.43087 & 2.82607 & -1.79071 \\
\hline
\end{tabular}




\begin{tabular}{|c|c|c|c|c|c|c|c|}
\hline \multicolumn{8}{|c|}{$6^{\mathrm{DIP}}$} \\
\hline \multicolumn{8}{|c|}{ UM062X/def2SVP, Total energy: -2115.04914818 hartree } \\
\hline c & -0.52282 & 1.03283 & -0.63647 & $\mathrm{H}$ & -2.22741 & 5.67527 & -0.05253 \\
\hline$C$ & 0.85401 & 1.01702 & -0.63792 & $\mathrm{H}$ & -3.01933 & 0.28965 & 2.24379 \\
\hline$C$ & 1.60194 & -0.02926 & -0.03598 & $\mathrm{H}$ & -1.49477 & -0.12744 & 4.08747 \\
\hline$C$ & 0.84934 & -1.06864 & 0.57187 & $\mathrm{H}$ & -0.62659 & 0.73289 & 2.78922 \\
\hline$C$ & -0.52759 & -1.06354 & 0.59594 & $\mathrm{H}$ & -1.13790 & 1.60528 & 4.25870 \\
\hline$C$ & -1.26985 & -0.00648 & -0.00805 & $\mathrm{H}$ & -3.99311 & 0.39408 & 4.50116 \\
\hline$C$ & -2.68921 & 0.01447 & 0.02352 & $\mathrm{H}$ & -4.85260 & 1.51832 & 3.41316 \\
\hline $\mathrm{N}$ & -3.41425 & -1.16334 & 0.14169 & $\mathrm{H}$ & -3.67976 & 2.14178 & 4.59153 \\
\hline$C$ & -3.01474 & -2.35394 & -0.55449 & $\mathrm{H}$ & -2.98248 & 2.61989 & -2.04234 \\
\hline$B$ & 3.14577 & -0.03048 & -0.03207 & $\mathrm{H}$ & -4.16531 & 4.47712 & -3.19800 \\
\hline $\mathrm{N}$ & -3.38415 & 1.21328 & -0.05798 & $\mathrm{H}$ & -4.99055 & 4.16577 & -1.64717 \\
\hline$C$ & -2.90646 & 2.39723 & 0.59968 & $\mathrm{H}$ & -3.89579 & 5.54685 & -1.80460 \\
\hline$C$ & -2.82216 & -3.55486 & 0.17172 & $\mathrm{H}$ & -1.64537 & 4.12247 & -3.41656 \\
\hline$C$ & -2.53722 & -4.72784 & -0.53154 & $\mathrm{H}$ & -0.67281 & 3.66255 & -1.99617 \\
\hline C & -2.39528 & -4.72822 & -1.91342 & $\mathrm{H}$ & -1.43190 & 5.26351 & -2.07579 \\
\hline C & -2.52918 & -3.53358 & -2.60848 & $\mathrm{H}$ & -3.17252 & -0.22755 & -2.17016 \\
\hline C & -2.84323 & -2.33619 & -1.95758 & $\mathrm{H}$ & -2.93268 & -2.60713 & 2.08614 \\
\hline C & -2.64748 & 2.38679 & 1.98894 & $\mathrm{H}$ & -4.10242 & -4.43974 & 3.29257 \\
\hline C & -2.25665 & 3.57997 & 2.60539 & $\mathrm{H}$ & -5.01111 & -4.08131 & 1.79955 \\
\hline$C$ & -2.13016 & 4.76321 & 1.88980 & $\mathrm{H}$ & -3.95541 & -5.49940 & 1.87340 \\
\hline$C$ & -2.35823 & 4.75436 & 0.51940 & $\mathrm{H}$ & -1.56167 & -4.16830 & 3.35723 \\
\hline C & -2.72286 & 3.58431 & -0.15104 & $\mathrm{H}$ & -0.66600 & -3.72369 & 1.88203 \\
\hline$C$ & -2.76622 & 1.15133 & 2.86976 & $\mathrm{H}$ & -1.47142 & -5.29981 & 1.99460 \\
\hline $\mathrm{C}$ & -1.42624 & 0.82419 & 3.53873 & $\mathrm{H}$ & -1.75670 & 0.16759 & -4.10529 \\
\hline$C$ & -3.88819 & 1.31055 & 3.90105 & $\mathrm{H}$ & -0.83190 & -0.71792 & -2.86424 \\
\hline$C$ & -2.84794 & 3.64691 & -1.66934 & $\mathrm{H}$ & -1.44905 & -1.57162 & -4.30353 \\
\hline $\mathrm{C}$ & -4.04837 & 4.49900 & -2.10443 & $\mathrm{H}$ & -4.28603 & -0.27963 & -4.36219 \\
\hline C & -1.57328 & 4.20112 & -2.32180 & $\mathrm{H}$ & -5.10553 & -1.39713 & -3.23694 \\
\hline$C$ & -2.98125 & -1.08845 & -2.81830 & $\mathrm{H}$ & -4.02309 & -2.03303 & -4.49252 \\
\hline$C$ & -2.85532 & -3.63292 & 1.69412 & $\mathrm{H}$ & 6.39728 & -2.75279 & 2.13391 \\
\hline$C$ & -4.05417 & -4.45116 & 2.19367 & $\mathrm{H}$ & 4.21735 & -4.55183 & -1.09155 \\
\hline$C$ & -1.56145 & -4.23631 & 2.25940 & $\mathrm{H}$ & 2.91033 & -3.24692 & -2.50701 \\
\hline$C$ & -1.67664 & -0.78796 & -3.56489 & $\mathrm{H}$ & 1.64622 & -2.76137 & -1.35661 \\
\hline$C$ & -4.16782 & -1.20640 & -3.78060 & $\mathrm{H}$ & 2.55703 & -1.52523 & -2.21724 \\
\hline $\mathrm{C}$ & 3.93265 & -1.39089 & 0.18677 & $\mathrm{H}$ & 4.39831 & 0.17567 & 2.46675 \\
\hline$C$ & 4.93776 & -1.49320 & 1.17923 & $\mathrm{H}$ & 5.91353 & -0.64313 & 2.90934 \\
\hline$C$ & 5.63305 & -2.69058 & 1.35344 & $\mathrm{H}$ & 5.84932 & 0.44514 & 1.49997 \\
\hline $\mathrm{C}$ & 5.38702 & -3.80782 & 0.55089 & $\mathrm{H}$ & 5.99404 & -5.78937 & -0.06818 \\
\hline $\mathrm{C}$ & 4.41287 & -3.69596 & -0.43889 & $\mathrm{H}$ & 7.22697 & -4.90030 & 0.85971 \\
\hline$C$ & 3.67843 & -2.51858 & -0.62694 & $\mathrm{H}$ & 5.82203 & -5.59076 & 1.68911 \\
\hline C & 2.64855 & -2.50855 & -1.73653 & $\mathrm{H}$ & -5.54539 & -1.24053 & 0.06702 \\
\hline$C$ & 5.29293 & -0.31972 & 2.06297 & $\mathrm{H}$ & -4.79542 & -2.09117 & 1.43097 \\
\hline$C$ & 6.14820 & -5.09015 & 0.76432 & $\mathrm{H}$ & -4.84089 & -0.32157 & 1.43003 \\
\hline$C$ & -4.71688 & -1.20458 & 0.79299 & $\mathrm{H}$ & 6.40792 & 2.70210 & -2.16855 \\
\hline$C$ & 3.93159 & 1.33202 & -0.24201 & $\mathrm{H}$ & 4.19993 & 4.49153 & 1.04313 \\
\hline$C$ & 4.94406 & 1.43799 & -1.22659 & $\mathrm{H}$ & 2.89571 & 3.17312 & 2.45457 \\
\hline C & 5.63793 & 2.63708 & -1.39401 & $\mathrm{H}$ & 1.63368 & 2.71073 & 1.29256 \\
\hline$C$ & 5.38318 & 3.75265 & -0.59176 & $\mathrm{H}$ & 2.52918 & 1.45758 & 2.14525 \\
\hline C & 4.40206 & 3.63707 & 0.39061 & $\mathrm{H}$ & 4.41785 & -0.22984 & -2.52080 \\
\hline C & 3.66876 & 2.45778 & 0.57173 & $\mathrm{H}$ & 5.93592 & 0.59111 & -2.94925 \\
\hline C & 2.63186 & 2.44489 & 1.67508 & $\mathrm{H}$ & 5.86070 & -0.49881 & -1.54167 \\
\hline$C$ & 5.30838 & 0.26607 & -2.10865 & $\mathrm{H}$ & 5.98068 & 5.73484 & 0.03448 \\
\hline$C$ & 6.14295 & 5.03705 & -0.79768 & $\mathrm{H}$ & 7.22287 & 4.84988 & -0.88494 \\
\hline$C$ & -4.72559 & 1.29054 & -0.62118 & $\mathrm{H}$ & 5.82277 & 5.53806 & -1.72434 \\
\hline $\mathrm{H}$ & -1.05948 & 1.82867 & -1.14680 & $\mathrm{H}$ & -4.82062 & 2.17816 & -1.25542 \\
\hline $\mathrm{H}$ & 1.39511 & 1.82955 & -1.13239 & $\mathrm{H}$ & -4.91810 & 0.41041 & -1.24489 \\
\hline $\mathrm{H}$ & 1.38713 & -1.88959 & 1.05608 & $\mathrm{H}$ & -5.50179 & 1.35229 & 0.15890 \\
\hline $\mathrm{H}$ & -1.06645 & -1.85178 & 1.11555 & & & & \\
\hline $\mathrm{H}$ & -2.40042 & -5.65883 & 0.02234 & & & & \\
\hline $\mathrm{H}$ & -2.16543 & -5.65290 & -2.44432 & & & & \\
\hline $\mathrm{H}$ & -2.39893 & -3.52610 & -3.69262 & & & & \\
\hline $\mathrm{H}$ & -2.05879 & 3.57850 & 3.67926 & & & & \\
\hline $\mathrm{H}$ & -1.83921 & 5.68516 & 2.39485 & & & & \\
\hline
\end{tabular}




\section{References}

(S1) Dorkó, E.; Varga, E.; Gáti, T.; Holczbauer, T.; Pápai, I.; Mehdi H.; Soós, T. Steric Control of Geminal Lewis pair Behaviour: Frustration Induced Dyotropic Rearrangement. Synlett 2014, 25, 1525-1528.

(S2) Weitz, I. S. ; Rabinovitz, M. The application of $\mathrm{C}_{8} \mathrm{~K}$ for organic synthesis: reduction of substituted naphthalenes J. Chem. Soc. Perkin Trans 1. 1993, 117-120.

(S3) Stoll, S.; Schweiger, A. EasySpin, a comprehensive software package for spectral simulation and analysis in EPR. J. Magn. Reson. 2006, 178, 42-55.

(S4) CrysAlisPro: Rigaku Oxford Diffraction (1995-2017). Oxford Diffraction Ltd, Abingdon, Oxfordshire, England.

(S5) Sheldrick, G. M. SHELXT-Integrated space-group and crystal-structure determination Acta Cryst. A 2015, 71, 38.

(S6) Sheldrick, G. M. Crystal structure refinement with SHELXL Acta Cryst. C 2015, 71, 3-8.

(S7) Dolomanov, O. V.; Bourhis, L. J.; Gildea, R. J.; Howard, J. A. K.; Puschmann, H. OLEX2: a complete structure solution, refinement and analysis program. J. Appl. Crystallogr. 2009, 42, 339-341.

(S8) Collins, M. S.; Rosen, E. L.; Lynch, V. M.; Bielawski, C. W. Differentially Substituted Acyclic Diaminocarbene Ligands Display Conformation-Dependent Donicities. Organometallics 2010, 29, 3047-3053.

(S9) Frisch, M. J.; Trucks, G. W.; Schlegel, H. B.; Scuseria, G. E.; Robb, M. A.; Cheeseman, J. R.; Scalmani, G.; Barone, V.; Petersson, G. A.; Nakatsuji, H.; Li, X.; Caricato, M.; Marenich, A. V.; Bloino, J.; Janesko, B. G.; Gomperts, R.; Mennucci, B.; Hratchian, H. P.; Ortiz, J. V.; Izmaylov, A. F.; Sonnenberg, J. L.; Williams; Ding, F.; Lipparini, F.; Egidi, F.; Goings, J.; Peng, B.; Petrone, A.; Henderson, T.; Ranasinghe, D.; Zakrzewski, V. G.; Gao, J.; Rega, N.; Zheng, G.; Liang, W.; Hada, M.; Ehara, M.; Toyota, K.; Fukuda, R.; Hasegawa, J.; Ishida, M.; Nakajima, T.; Honda, Y.; Kitao, O.; Nakai, H.; Vreven, T.; Throssell, K.; Montgomery Jr., J. A.; Peralta, J. E.; Ogliaro, F.; Bearpark, M. J.; Heyd, J. J.; Brothers, E. N.; Kudin, K. N.; Staroverov, V. N.; Keith, T. A.; Kobayashi, R.; Normand, J.; Raghavachari, K.; Rendell, A. P.; Burant, J. C.; Iyengar, S. S.; Tomasi, J.; Cossi, M.; Millam, J. M.; Klene, M.; Adamo, C.; Cammi, R.; Ochterski, J. W.; Martin, R. L.; Morokuma, K.; Farkas, O.; Foresman, J. B.; Fox, D. J. Gaussian 16 Rev. C.01, Wallingford, CT, 2016. 